UNIVERSIDADE ESTADUAL PAULISTA “JULIO DE MESQUITA FILHO"

CAMPUS DE MARÍLIA

PROGRAMA DE PÓS-GRADUAÇÃ̃O EM EDUCAÇÃO

SILVIA CRISTINA DE SOUZA

MECANISMOS DE QUASE-MERCADO NA EDUCAÇÃO

ESCOLAR PÚBLICA BRASILEIRA

MARÍLIA

2010 
SILVIA CRISTINA DE SOUZA

\section{MECANISMOS DE QUASE-MERCADO NA EDUCAÇÃO ESCOLAR PÚBLICA BRASILEIRA}

Tese apresentada ao Programa de PósGraduação em Educação, da Faculdade de Filosofia e Ciências da Universidade Estadual Paulista "Julio de Mesquita Filho", Campus de Marília, como parte das exigências para a obtenção do título de Doutor (Área de Concentração: Políticas Públicas e Administração da Educação Brasileira) sob a orientação da Professora Dra. Maria Sylvia Simões Bueno.

\section{MARÍLIA}


Ficha Catalográfica elaborada pelo

Serviço Técnico de Biblioteca e Documentação - UNESP - Campus de Marília

Souza, Silvia Cristina de.

S729m Mecanismos de quase-mercado na educação escolar pública brasileira / Silvia Cristina de Souza. - Marília, 2010. $149 \mathrm{f} . ; 30 \mathrm{~cm}$.

Tese (Doutorado em Educação) - Faculdade de Filosofia e Ciências, Universidade Estadual Paulista, 2010.

Bibliografia: f. 140-149

Orientadora: Prof $^{\mathrm{a}}$. Dr ${ }^{\mathrm{a}}$. Maria Silvia Simões Bueno

1 Quase-mercado educacional. 2. Gestão. 3. Avaliação.

4. Formação de professores. I. Autor. II. Título. 
SILVIA CRISTINA DE SOUZA

\title{
MECANISMOS DE QUASE-MERCADO NA EDUCAÇÃO ESCOLAR PÚBLICA BRASILEIRA
}

\begin{abstract}
Tese apresentada ao Programa de PósGraduação em Educação, da Faculdade de Filosofia e Ciências da Universidade Estadual Paulista "Julio de Mesquita Filho", Campus de Marília, como parte das exigências para a obtenção do título de Doutor (Área de Concentração: Políticas Públicas e Administração da Educação Brasileira) sob a orientação da Professora Dra. Maria Sylvia Simões Bueno.
\end{abstract}

\section{BANCA EXAMINADORA}

$\operatorname{Prof}^{\mathrm{a}} \mathrm{Dr}^{\mathrm{a}}$ Maria Sylvia Simões Bueno (Orientadora) - UNESP/Campus de Marília

Prof $^{\mathrm{a}} \mathrm{Dr}^{\mathrm{a}}$ Graziela Zambão Abdian Maia - UNESP/Campus de Marília

Prof $^{a} \operatorname{Dr}^{\mathrm{a}}$. Iraíde Marques de Freitas Barreiro - UNESP/Campus de Assis

$\operatorname{Prof}^{a} \operatorname{Dr}^{\mathrm{a}}$. Theresa Maria de Freitas Adrião - UNICAMP/Campinas

Prof. Dr. Pedro Ganzeli - UNICAMP/Campinas

MARÍLIA

2010 
Dedico este trabalho a minha mãe Elza e as minhas irmãs Márcia e Marta, as pessoas mais especiais da minha vida. 


\section{AGRADECIMENTOS}

Agradecimentos especiais a todos aqueles que, de alguma maneira, contribuíram para realização deste trabalho.

À professora Maria Sylvia Simões Bueno, pela confiança e incentivo. Sua segurança e apoio foram fundamentais na minha caminhada acadêmica.

As amigas do coração e da alma Ana Claudia Celice Alves Vasconcelos e Maria Angélica Pinto de Arruda. Amo vocês!

Aos amigos de trabalho do Centro Universitário Toledo de Araçatuba, pelo apoio e incentivo, especialmente aos queridos Sérgio, Ana Maria, Pedro Márcio, Ângela, Lia e Marcela.

Ao Bruno Roberto Pereira de Toledo, pela amizade e incentivo.

A Prefeitura Municipal de Birigui, especialmente ao Sr. Prefeito Municipal Wilson Carlos Rodrigues Borini, Prof. Paulo Batista e Prof Sonia Regina Guaraldo, pela oportunidade de concluir meu doutorado.

Aos professores do programa de pós-graduação em Educação da Universidade Estadual Paulista - UNESP, Campus de Marília, pelos preciosos ensinamentos.

Aos professores $\operatorname{Dr}^{\mathrm{a}}$ Graziela Zambão Abdian Maia, $\mathrm{Dr}^{\mathrm{a}}$. Iraíde Marques de Freitas Barreiro, Dr ${ }^{\mathbf{a}}$ Theresa Adrião e Dr Pedro Ganzeli, por participarem de minhas bancas e colaborarem com meu trabalho. 


\section{RESUMO}

Realizado mediante procedimentos de pesquisa bibliográfica e pesquisa documental, o presente trabalho analisa as evidências da presença do quase-mercado na política educacional brasileira. Analisa, em particular, na legislação e nos documentos de apresentação e divulgação das políticas educacionais, as concepções de gestão, avaliação educacional e formação de professores, buscando identificar possíveis convergências de sentido e compromissos com a implantação de mecanismos de quasemercado. Inicialmente, apresenta uma análise do surgimento do quase-mercado no contexto da nova gestão pública nos países centrais. $\mathrm{Na}$ seqüência, examina o movimento de reforma do Estado brasileiro, revelando a emergência do mercado nesse contexto. Apresenta a reforma educacional como elemento da reforma do Estado, evidenciando a similaridade de objetivos. Em seguida, revela as novas articulações entre público, privado e público-não-estatal. Por fim, apresenta os resultados da pesquisa documental apontando as concepções de gestão educacional, avaliação da educação básica e formação de professores e sua convergência com o ideário de implantação de mecanismos de quase-mercado educacional.

Palavras-chave: Quase-mercado educacional, gestão, avaliação, formação de professores 


\begin{abstract}
The present paper examines the evidence for the presence of quasi-market in the Brazilian educational policy through a bibliographic and documentary research. It examines, particularly, in legislation and in documents for presentation and dissemination of the educational policies, management concepts, educational assessment and teacher training, aiming at identifying possible convergences of meaning and commitment to the implementation of quasi-market mechanisms. Initially, it presents an analysis of the quasi-market emergence in the context of new public management in the central countries. Then, it shows the reform movement of the Brazilian state, revealing the emergence of the market in this context. It presents the educational reform as part of the state reform, highlighting the similarity of objectives. After that, it reveals new connections among public, private and public non-state. Finally, it presents the results of the document research pointing the concepts of educational management, evaluation of basic education and training of teachers and their convergence on the ideal deployment of quasi-market mechanisms in education.
\end{abstract}

Keywords: Quasi-market education, management, evaluation, teachers training professores 


\section{LISTA DE QUADROS}

Quadro 1 Categorias de análise.

Quadro 2 Estratégias propostas pela Nova Direita - providências e desdobramentos...27 


\section{LISTA DE ABREVIATURAS E SIGLAS}

ANEB - Avaliação Nacional da Educação Básica

ANRESC - Avaliação Nacional do Rendimento Escolar

BR - Bonificação por Resultados

CAPES - Coordenação de Aperfeiçoamento de Pessoal de Nível Superior

CNE/CP - Conselho Nacional de Educação/Conselho Pleno

CONED - Congresso Nacional de Educação

ENC - Exame Nacional de Cursos

ENCCEJA - Exame Nacional para Certificação de Competências de Jovens e Adultos

ENEM - Nacional do Ensino Médio

FHC - Fernando Henrique Cardoso

FUNDEF - Fundo de Manutenção e Desenvolvimento do Ensino Fundamental e de

Valorização do Magistério

IDEB - Índice de Desenvolvimento da Educação Básica

INEP - Instituto Nacional de Pesquisas Educacionais

ISE - Institutos Superiores de Educação

LDB - Lei de Diretrizes e Bases da Educação Nacional

MARE - Ministério da Administração Federal da Reforma do Estado

MEC - Ministério da Educação

OCDE - Organização para a Cooperação e o Desenvolvimento Econômico

OSCs - Organizações da Sociedade Civil

PAC - Programa de Aceleração do Crescimento

PCN - Parâmetros Curriculares Nacionais

PDE - Plano de Desenvolvimento da Educação 
PIBID - Programa Institucional de Bolsas de Iniciação à Docência

PNE - Plano Nacional de Educação

PQE - Programa de Qualidade da Escola

PROUNI - Programa Universidade para Todos

SAEB - Sistema Nacional de Avaliação da Educação Básica (SAEB),

SARESP - Sistema de Avaliação de Rendimento Escolar do Estado de São Paulo

TGA - Teoria Geral da Administração

UAB - Universidade Aberta do Brasil 
INTRODUÇÃ

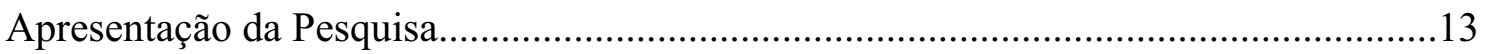

Procedimentos metodológicos.....................................................................................

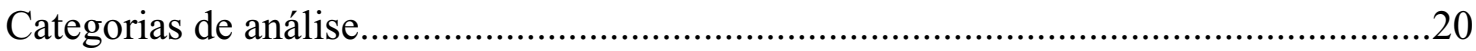

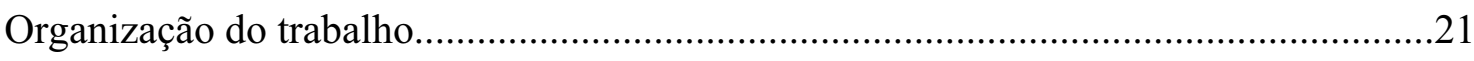

CAPÍTULO I - O QUASE-MERCADO EDUCACIONAL NO CONTEXTO DA RESSIGNIFICAÇÃO DO PAPEL DO ESTADO: EVIDÊNCIAS E

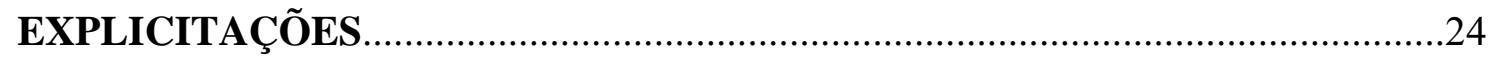

1.1 Quase-mercado educacional - primeiras aproximações..............................................25

1.2 A reforma do Estado e a emergência do mercado.......................................................38

1.3 A reforma educacional brasileira no contexto da reforma de Estado: mercado e

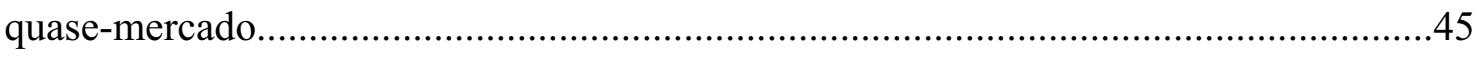

\section{CAPítulo II - QUASE-MERCADO E A PARTICIPAÇÃo DO PÚBLICO

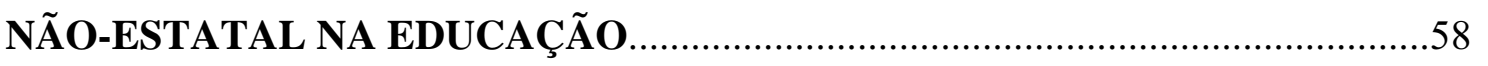

2.1 Público, Privado e Público não-Estatal: articulações em torno da oferta dos serviços educacionais

2.2 A atuação das organizações públicas não-estatais na educação pública brasileira: nem Estado, nem Mercado: Quase-mercado .65

\section{CAPÍTUlO III- A GESTÃo EDUCACIONAL NA PERSPECTIVA DO QUASE-} MERCADO: o que dizem os documentos oficiais.

3.1 A Gestão nas recentes políticas educacionais brasileiras: breve estudo do conceito e de seu significado. .74

3.2 A Gestão Educacional na Constituição Federal de 1988 e na Lei de Diretrizes e Bases da Educação Nacional: evidências da presença do quase-mercado.........................77

3.3 A Gestão Educacional no Plano Nacional de Educação .............................................82

3.4 A Gestão Educacional no Plano de Desenvolvimento da Educação............................92 
4.1 Sistema Nacional de Avaliação da Educação Básica - SAEB.................................102

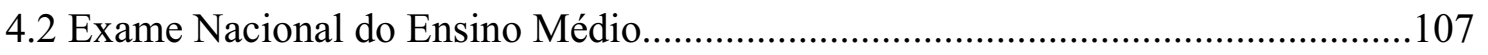

4.3 Índice de Desenvolvimento da Educação Básica ..................................................113

CAPÍtULO V - O QUASE-MERCADO NA FORMAÇÃO DE

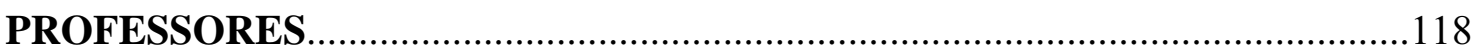

5.1 A formação de professores no contexto da Lei $\mathrm{n}^{0}$ 9394, de 20 de Dezembro de

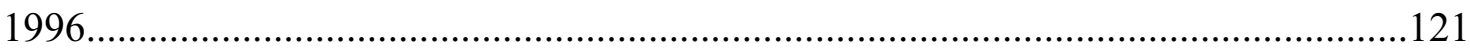

5.2 Diretrizes Curriculares Nacionais para a Formação de Professores da Educação

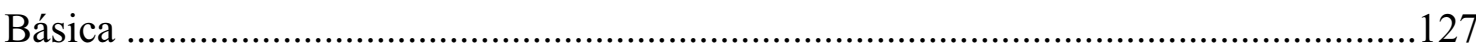

5.3 A formação dos Professores no Plano de Desenvolvimento da Educação...............131

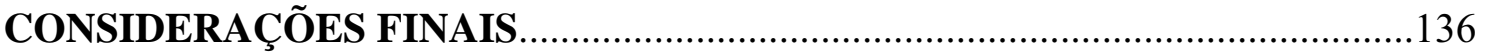

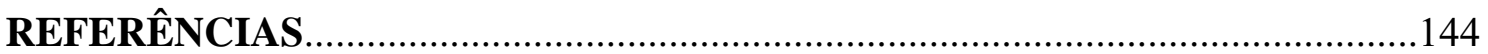


INTRODUÇÃO 


\section{Apresentação da Pesquisa}

As reformas educacionais têm sido discutidas exaustivamente nos últimos vinte anos. Questões como descentralização, autonomia, avaliação, formação de professores e privatização são tratadas tendo como pano de fundo o movimento de reestruturação/ressignificação do papel do Estado que imprimiu uma nova lógica de minimização em termos de atuação e que, como conseqüência, redirecionou as políticas públicas, em especial as voltadas para a área social.

É fato que a reforma do Estado brasileiro, ocorrida nos anos de 1990, é o marco referencial das atuais políticas educacionais, posto que estas últimas são parte daquele amplo "pacote" reformista. Nesse sentido, revelam os mesmos compromissos e descompromissos do Estado para com as questões sociais.

A esse respeito, inúmeros autores brasileiros evidenciaram, por meio da divulgação de suas pesquisas, a natureza e o caráter das políticas educacionais. Autores como AZEVEDO (1997), BUENO (2004), BUENO et al (2002), CAMARGO, PINTO e GUIMARÃES (2008), DOURADO e BUENO (2001), GENTILI e SILVA (1995), KRAWCZYK (2001), MARTINS (2001), OLIVEIRA (2006) e SOUSA (2003), para citar apenas alguns deles, abordaram o tema e revelaram os diferentes aspectos relacionados à política educacional.

Cumpre destacar que uma questão emergente nos estudos que tratam das políticas educacionais é a consolidação de uma proposta de reorganização da gestão educacional que se traduz na mercadorização dos processos. Trata-se, pois, da interpenetração do público e do privado, numa perspectiva que visa a transplantação da lógica privada para a gestão da educação pública. 
Embora em tais processos o mercado seja tomado como referência e expressão "material" da atuação do setor privado, não se constitui estratégia de privatização propriamente dita, mas de introdução de mecanismos mercantis no interior da gestão da educação pública.

O Estado, nesse contexto, deixa de ser o provedor único da educação, que agora é entendida como serviço não-exclusivo do mesmo, que não necessariamente deve ser executado/prestado por ele, mas regulado, facilitado, promovido ou parcialmente financiado. Conforme indica Coutinho (2003), o Estado deixou de ser o executor (único) e passou a ser o coordenador desse serviço.

A introdução de instrumentos de gestão privada colabora para o intento de ressignificação do papel do Estado, na medida em que, por meio de tais mecanismos, o Estado se mantém visível, transfere responsabilidades e cobra resultados. A visibilidade do Estado se concretiza através da prescrição de normas, currículos e diretrizes, enquanto a transferência de responsabilidades e a cobrança de resultados se dão, especialmente, pela via da competição que a avaliação, como instrumento de regulação do Estado, suscita.

Esse processo de mercantilização ou mercadorização da educação foi denominado "quase-mercado educacional" e tem sido objeto de estudo de autores como Whitty e Power (2002), Afonso (1998, 1999, 2003), Sá (2008), Sousa (2001, 2003), Souza e Bueno (2007), entre outros.

Importa destacar que os diferentes autores que tratam da introdução de mecanismos de quase-mercado na educação pública concordam que se trata de um movimento crescente que traduz as concepções de educação assumidas pelos diferentes países que adotam tal sistemática. Trata-se, pois, da relativização da educação como 
direito social e conseqüente assunção de uma lógica de cunho privado, onde a educação é reduzida à condição de mercadoria.

Os trabalhos dedicados à questão do quase-mercado educacional abordam desde a escolha parental, passando pela avaliação, formação de professores e gestão dos sistemas educativos. Importa destacar, contudo, que os focos variam conforme as características dos países analisados, todavia os resultados são bastante semelhantes em relação às conseqüências advindas da introdução de tal política.

Isto posto, procuramos nessa pesquisa analisar como a lógica mercantil está presente na legislação e nos documentos que tratam da política educacional brasileira. Foram selecionadas leis, decretos e resoluções vigentes, além dos documentos oficiais de apresentação e divulgação de programas, que pudessem revelar concepções de gestão, avaliação e formação de professores pautados pela lógica mercantil.

Cumpre esclarecer que o interesse pelo estudo das políticas de quasemercado educacional - presente nessa investigação - nasceu em decorrência de outra investigação empreendida durante os estudos de mestrado. Naquele momento buscávamos compreender os processos de criação de sistemas municipais de ensino no contexto da descentralização da educação imposta pela reforma educacional brasileira das décadas de 1980 e 1990. Tomamos como referência a experiência de três municípios paulistas.

Constatamos, naquele momento, que a opção pela criação de sistemas autônomos de ensino constituía-se como desdobramento das políticas de cunho descentralista, uma vez que aos municípios haviam sido impostas inúmeras obrigações no que se referia à responsabilidade pela oferta e financiamento da educação 
obrigatória; contudo reconhecia-se, pela primeira vez, o direito das municipalidades serem titulares de seus sistemas de ensino, ampliando, dessa forma, a possibilidade da implantação de uma gestão educacional própria. Diante dessa possibilidade, municípios organizaram-se e, a despeito de resistências impostas, criaram seus sistemas de ensino e inauguraram, ao menos em tese, uma gestão autônoma de educação.

Entretanto, pudemos perceber, nesse mesmo estudo, que as políticas descentralistas promoveram, ao longo dos últimos anos, uma série de outros desdobramentos.

Se a autonomia e ampliação da democratização da gestão do ensino foram as grandes promessas das políticas descentralistas de educação - materializadas principalmente pelos processos de municipalização do ensino fundamental -, na prática o que se pode observar foi o aumento do autoritarismo das redes locais, a implantação de mecanismos de controle mais severos e a imposição de modelos educativos ainda mais descolados da realidade das escolas.

É nesse contexto, portanto, que os mecanismos de quase-mercado educacional passaram a ser implantados. Se a descentralização da educação não foi condição para a introdução da lógica mercantil, ao menos foi, em termos organizacionais, facilitadora.

Importa recordar que as reformas educativas assentaram-se em pressupostos que buscavam minimizar o papel do Estado enquanto provedor desse serviço social, ampliando, em contrapartida, sua força reguladora. Assim, conforme aponta Afonso (1999), mantém-se a idéia de que o Estado, ao impor regras e normas e avaliar os resultados, estaria preocupado com seus consumidores e com a necessidade 
de elevar os níveis educacionais. Entretanto, promoveu-se aqui uma desresponsabilização do Estado e uma responsabilização dos atores educativos.

Portanto, o estudo que ora apresentamos tem por objetivos:

1- Compreender o conceito de quase-mercado, as características de tal mecanismo e suas manifestações nas políticas educacionais.

2- Analisar os documentos da política educacional brasileira no que diz respeito, especificamente, à implantação de mecanismos de quase-mercado na educação.

3- Analisar como tais políticas concebem a gestão educacional, a avaliação da educação básica e a formação de professores.

No intuito de se construir um referencial que possibilitasse alcançar os objetivos do estudo, estabelecemos os procedimentos metodológicos que serão apresentadas na seção seguinte.

\section{Procedimentos metodológicos}

Os procedimentos metodológicos e técnicas de coleta de dados abrangeram pesquisa bibliográfica e pesquisa documental. Em relação à pesquisa bibliográfica, realizou-se levantamento, seleção e estudo de textos, artigos científicos, teses e livros sobre a temática.

A coleta de dados realizou-se mediante a utilização da técnica de análise documental.

Em relação aos documentos, optamos por analisar a Constituição Federal de 1988 e a Lei de Diretrizes e Bases da Educação Nacional - LDB - por expressarem os princípios gerais (Constituição Federal) e as diretrizes (LDB) da 
educação nacional, e, portanto, constituírem-se nos documentos basilares da política educacional brasileira. Analisamos, ainda, Leis, Resoluções, Pareceres e Decretos que pudessem indicar concepções acerca de gestão educacional, avaliação da educação básica e formação de professores, buscando identificar possíveis propostas ou idéias ligadas à implantação de mecanismos de quase-mercado na educação básica pública. Buscamos analisar normas em vigor no ano de 2010.

Os documentos que serviram de base para a análise compreendem:

- Leis Federais (Constituição Federal de 1988, Lei nº 9394/96 - Lei de Diretrizes e Bases da Educação Nacional - LDB);

- Planos Nacionais - leis de criação e documentos oficiais de apresentação (Plano Nacional de Educação (PNE), Plano de Desenvolvimento da Educação (PDE));

- Decretos de criação e documentos oficiais de apresentação de Programas (Sistema Nacional de Avaliação da Educação Básica - SAEB , Exame Nacional do Ensino Médio - ENEM, Índice de Desenvolvimento da Educação Básica IDEB);

- Resolução que trata da formação de professores da educação básica (Resolução CNE/CP n ${ }^{\circ}$, de 18 de fevereiro de 2002 instituiu as Diretrizes Curriculares Nacionais para a Formação de Professores da Educação Básica, em nível superior, curso de licenciatura, de graduação plena).

A busca dos documentos se deu por meio de consulta via internet nas páginas oficiais do Ministério da Educação, Conselho Nacional de Educação e Instituto Nacional de Pesquisas Educacionais - INEP. Documentos de apresentação dos planos e programas também foram consultados em bibliotecas. 
Os dados coletados foram analisados por meio da técnica denominada análise do conteúdo. Segundo Godoy (1995) essa técnica é uma das mais utilizadas para este fim.

\begin{abstract}
A análise do conteúdo consiste em um instrumental metodológico que se pode aplicar a discursos diversos e a todas as formas de comunicação, seja qual for a natureza do seu suporte.

Embora na sua origem a análise do conteúdo tenha privilegiado as formas de comunicação oral e escrita, não exclui outros meios de comunicação. Qualquer comunicação que veicule um conjunto de significações de um emissor para um receptor pode, em princípio, ser decifrada pelas técnicas de análise de conteúdo. Ela parte do pressuposto de que, por trás do discurso aparente, simbólico e polissêmico, esconde-se um sentido que convém desvendar. (GODOY, 1995, p. 23)
\end{abstract}

Bardin (1977) descreve a análise de conteúdo como um conjunto de

técnicas de análise das comunicações, que utiliza procedimentos sistemáticos e objetivos de descrição do conteúdo das mensagens. A inferência de conhecimentos relativos às condições de produção (ou recepção) é a intenção da análise e tal inferência recorre a indicadores quantitativos ou não.

Essa técnica exige do pesquisador a busca pela compreensão das características estruturas e/ou modelos que estão por trás dos fragmentos de mensagens analisados (Godoy, 1995).

A opção pela técnica de análise do conteúdo exige a definição de categorias de análise que podem ser elaboradas previamente (categorias definidas $a$ priori) e outras não previamente definidas.

O uso de categorias elaboradas a priori visam a busca por respostas específicas do investigador, enquanto as categorias não definidas previamente emergem do discurso, do conteúdo a ser analisado.

Optamos pelo estabelecimento prévio das categorias de análise, como forma de facilitar a obtenção de respostas às indagações iniciais da pesquisa. 
Para Franco (2008), “formular categorias, em análise de conteúdo, é, via de regra, um processo longo, difícil e desafiante". O desenvolvimento dessa pesquisa nos mostrou claramente tal dificuldade. A princípio elegemos categoriais que não se mostraram satisfatórias para o desenvolvimento da pesquisa e que pouco contribuíam, em termos metodológicos, para o alcance das respostas. Assim, redefinimos as categorias na busca de que elas pudessem nos oferecer, conforme indica Franco (2008), resultados férteis.

As categorias eleitas serão apresentadas a seguir.

\section{Categorias de análise}

O levantamento bibliográfico, realizado para discutir as políticas educacionais de introdução de mecanismos de quase-mercado na educação pública, revelou a necessidade de definição de categorias de análise como forma de guiar a pesquisa acerca das evidências de incidência desses mecanismos nos documentos oficiais que tratam da gestão escolar, avaliação educacional e formação de professores.

O estabelecimento de categorias de análise permite a simplificação do material a ser analisado, facilitando a compreensão de seu sentido. Trata-se de procedimento importante, uma vez que a definição das categorias de análise permite a sistematização das informações coletadas e a elaboração das inferências, a partir de ampliação da compreensão de tais informações.

O quadro a seguir apresenta as categorias de análise definidas. 
Quadro 2 - Categorias de Análise

\begin{tabular}{l|l}
\hline \multicolumn{1}{c|}{ Categorias } & \multicolumn{1}{c}{ Subcategorias } \\
\hline Gestão & Gestão educacional \\
& Gestão de sistemas educativos \\
& Gestão escolar \\
& Gestão da escola pública \\
\hline Avaliação da Educação Básica & Sistema de Avaliação \\
& Avaliação em larga escala \\
& Avaliação de Rendimento Escolar \\
\hline Formação de professores & \\
\hline
\end{tabular}

Cumpre esclarecer que a escolha das categorias gestão, avaliação e formação de professores se deu em função dos objetivos da pesquisa.

Como já exposto anteriormente, pretendíamos analisar a possível presença da lógica mercantil na legislação e nos documentos da política educacional brasileira, assim, e partir da construção do referencial teórico, entendemos que, principalmente no caso brasileiro, a gestão, a avaliação e a formação de professores eram as áreas em que a presença do quase-mercado poderia ser mais claramente percebida.

\section{Organização do trabalho}

O presente estudo foi organizado em cinco capítulos.

$\mathrm{O}$ primeiro capítulo trata dos aspectos teóricos relacionados à concepção de quase-mercado educacional, sua origem, contexto de criação e implementação.

Ainda no capítulo inicial, analisamos o quase-mercado educacional no contexto da reforma do Estado e reforma educativa da década de 1990. 
O capítulo II aborda a questão da emergência do Terceiro Setor na oferta dos serviços educacionais. Partindo da análise das articulações entre as esferas pública, privada e pública-não-estatal, analisa-se a participação do terceiro setor nas políticas educacionais, entendida como desdobramento do processo de mercantilização da educação.

O terceiro capítulo trata da gestão educacional nos documentos oficiais. Iniciamos o capítulo com um breve estudo do conceito de gestão e analisamos, em seguida as concepções de gestão expressas na Constituição Federal, Lei de Diretrizes e Bases da Educação Nacional, Plano Nacional de Educação e Plano de Desenvolvimento da Educação.

O quarto capítulo apresenta uma análise sobre as concepções de avaliação presentes nos documentos oficiais que tratam do Sistema Nacional de Avaliação da Educação Básica - SAEB, do Exame Nacional do Ensino Médio - ENEM e do Índice de Desenvolvimento da Educação Básica - IDEB.

O quinto capítulo discute o quase-mercado nas políticas de formação de professores. Para tanto, apresentamos uma análise da Lei de Diretrizes e Bases da Educação Nacional, das Diretrizes Curriculares Nacionais para Formação de Professores da Educação Básica e do Plano de Desenvolvimento da Educação.

Por fim, na seqüência do quinto e último capítulo, apresentamos as considerações finais a respeito da pesquisa realizada. 
CAPÍTULO 1

O QUASE-MERCADO EDUCACIONAL NO CONTEXTO DA RESSIGNIFICAÇÃO DO PAPEL DO ESTADO: EVIDÊNCIAS E EXPLICITAÇÕES. 


\subsection{Quase-mercado educacional - primeiras aproximações}

Quase-mercado educacional, em termos conceituais, é uma derivação de quase-mercado, conceito criado no início da década de 1990 por Julian Le Grand, na tentativa de dar nome a determinadas especificidades presentes no processo de reforma do Estado Inglês, iniciado em meados dos anos de 1980.

Cumpre destacar que o governo da primeira-ministra Margareth Thatcher tinha como uma das grandes metas o corte de custos públicos e a melhoria da eficiência no setor. Para tanto, adotou medidas direcionadas ao ajuste fiscal, além da liberalização da economia, acompanhada de estratégias de privatização e desregulamentação, diminuindo, dessa forma, a atuação do Estado.

A reforma do Estado Inglês se deu, conforme aponta Anderson (1995) por meio de um programa de ajustes de cunho neoliberal. O autor destaca que "O modelo inglês foi, ao mesmo tempo, o pioneiro e o mais puro" (p. 12). E mais:

Os governos Thatcher contraíram a emissão monetária, elevaram as taxas de juros, baixaram drasticamente os impostos sobre os rendimentos altos, aboliram controles sobre os fluxos financeiros, criaram níveis de desemprego massivos, aplastaram greves, impuseram uma nova legislação antisindical e cortaram gastos sociais. E, finalmente - esta foi uma medida surpreendentemente tardia -, se lançaram num amplo programa de privatização, começando por habitação pública e passando em seguida a indústrias básicas como o aço, a eletricidade, o petróleo, o gás e a água. Esse pacote de medidas é o mais sistemático e ambicioso de todas as experiências neoliberais em países de capitalismo avançado (ANDERSON, 1995, p.12).

Implantou-se, ainda, um novo modelo de administração pública, um modelo gerencial, em contraponto ao modelo burocrático instalado. O modelo de administração gerencial, denominado de Nova Gestão Pública, tinha como objetivos a busca pela qualidade dos serviços, a descentralização e a avaliação desses por seus 
consumidores. Esse novo modelo de gestão, conforme aponta Fleury (2001), envolvia um conjunto de discussões acerca da transição de um paradigma burocrático de administração pública para um novo paradigma gerencial que considerava as mudanças no ambiente e incorporava ferramentas gerenciais utilizadas com êxito pelo mercado.

Embora tenha percorrido fases distintas ao longo do processo de reforma inglesa, a Nova Gestão Pública teve sempre o mercado como foco. Assim, introduziu na gestão mecanismos mercantis, que reproduziam uma situação de mercado no seio do setor público.

Abrucio (1999) destaca que a implantação do modelo de administração gerencial na Inglaterra avançou apoiada em três teorias que traziam distintos objetivos e relações com os públicos-alvos: Modelo Gerencial Puro, Consumerism, Public Service Orientation.

Segundo ao autor, o Modelo Gerencial Puro tinha como eixo central a produtividade e a busca pela eficiência. De início, promoveu o corte de custos e de pessoal.

O segundo modelo adotado, o Consumerism, propunha uma gestão mais flexível, a melhora na qualidade dos serviços, atendendo, dessa forma, as demandas do consumidor, visto nessa perspectiva como cliente.

O terceiro modelo, ou Public Service Orientation, evolui para uma visão mais amplificada de gestão gerencial, onde transparência, participação, accountability, equidade e justiça eram referenciais importantes. A visão de consumidor e cliente foi substituída pela visão de cidadão (coletivo).

O que de significativo se revela nesse processo é o fato de que embora possa parecer que essa ida ao mercado, em termos gerenciais, tenha trazido um 
abrandamento do Estado e de sua autoridade, o que ocorreu foi uma combinação entre a ampliação da atuação do mercado e o aumento de controle do Estado.

Essa idéia fica mais clara se considerarmos que a reforma inglesa combinou em seus processos de implantação a descentralização, a privatização e a introdução de mecanismos gerenciais na gestão pública.

Afonso (1999), ao analisar as políticas dos países centrais nos anos de 1980 e $1990^{1}$, aponta para a emergência de políticas da nova direita ${ }^{2}$, que "de forma muito distinta de políticas anteriores, também de direita, foram marcadas por uma singularidade própria: uma combinação da defesa da livre economia, de tradição liberal, com a defesa da autoridade do Estado, de tradição conservadora" (p. 141).

Nos países centrais, inclua-se a Inglaterra, a expansão do mercado não teve como conseqüência o desaparecimento do Estado-providência, conforme indica o autor. Entretanto, o Estado-providência foi reeditado, num modelo que buscava "gerir a tensão resultante da não diminuição das exigências em relação aos direitos sociais (nomeadamente na área da saúde e da educação) e da crescente escassez de receitas provenientes dos impostos (entretanto muito perto dos limites eleitoralmente suportáveis)" (AFONSO, 1999, p. 142).

Afonso, apoiado em Salter (1995), indica quais estratégias foram implementadas pela nova direita a fim de gerir as tensões entre as demandas por serviços sociais e a escassez de recursos para seu oferecimento. Nessa situação, três estratégias foram consideradas: a primeira consistia na redefinição do que se entendia

\footnotetext{
${ }^{1} \mathrm{O}$ autor toma como referência a obra de Andrew Gamble "The free economy and the strong State" - que analisa as políticas nos Estados Unidos e Inglaterra.

${ }^{2}$ De uma forma geral, as correntes da nova direita querem repensar e propor novos parâmetros para as sociedades capitalistas avançadas frente à crise do Estado de Bem-Estar, seja através da justificativa teórica do antiigualitarismo ou de propostas de cortes nas políticas de bem-estar social. (ALVES, 2000 p.189)
} 
por direitos ligados ao Estado-providência; a segunda buscava manter um melhor equilíbrio entre oferta e procura, visando maior eficiência no uso dos recursos públicos; e a terceira estratégia consistia em buscar fontes alternativas de financiamento.

No quadro abaixo comparo as três estratégias apontadas no que se referem as providências e possíveis desdobramentos resultantes de sua aplicação.

\section{Quadro 1 - Estratégias propostas pela Nova Direita - providências e desdobramentos}

\begin{tabular}{|c|c|c|}
\hline Estratégias & Providências & Desdobramentos \\
\hline $\begin{array}{l}\text { Redefinição do que se entende por } \\
\text { direitos ligados ao Estado- } \\
\text { providência }\end{array}$ & $\begin{array}{l}\text { Convencer os cidadãos a reduzir ou, } \\
\text { pelo menos, a não aumentar os seus } \\
\text { direitos }\end{array}$ & $\begin{array}{l}\text { Não é uma estratégia plausível a } \\
\text { curto prazo dada a hegemonia dos } \\
\text { valores do Estado-providência }\end{array}$ \\
\hline $\begin{array}{l}\text { Melhorar o equilíbrio entre oferta e } \\
\text { procura por serviços sociais }\end{array}$ & $\begin{array}{l}\text { Redirecionar a procura para o setor } \\
\text { privado }\end{array}$ & $\begin{array}{l}\text { Pressupõe a criação de incentivos } \\
\text { para que esse setor possa aumentar } \\
\text { sua capacidade de atendimento, e os } \\
\text { cidadãos sejam persuadidos de que } \\
\text { não perdem direitos porque poderão } \\
\text { fazer escolhas mais amplas e ter } \\
\text { acesso a serviços de melhor } \\
\text { qualidade }\end{array}$ \\
\hline $\begin{array}{l}\text { Buscar fontes alternativas de } \\
\text { financiamento }\end{array}$ & $\begin{array}{l}\text { Adotar medidas tendentes a atenuar } \\
\text { as fronteiras entre o setor público e o } \\
\text { setor privado, de modo a permitir } \\
\text { que se torne igualmente menos } \\
\text { nítida a distinção entre os direitos } \\
\text { sociais e os direitos individuais. }\end{array}$ & $\begin{array}{l}\text { Pode levar ao enfraquecimento da } \\
\text { hegemonia dos valores do Estado- } \\
\text { providência e, conseqüentemente, a } \\
\text { uma redução da procura dos serviços } \\
\text { públicos. }\end{array}$ \\
\hline
\end{tabular}

Fonte: criado a partir de Afonso (1999)

É perceptível, na análise das estratégias apontadas, a combinação de idéias de matriz conservadora e liberal, algo típico da nova direita. O fato é que, 
conforme indica Afonso, algumas dessas estratégias foram implementadas. Tais estratégias, portanto, “configuraram o que alguns autores têm vindo a designar como mecanismos de quase-mercado" (1999, p. 143).

Importa ressaltar que a Inglaterra não foi o único país a produzir uma reforma orientada pelo mercado, todavia pode-se considerar que foi pioneiro e modelar em muitos de seus aspectos. Segundo WILLIANS,

(...) as reformas empreendidas durante a era Thatcher orientaram-se essencialmente pelo enfoque mercadológico e representaram duas formas de privatização: a plena e a parcial ou de quase-mercados. A privatização plena deu-se pela venda de serviços públicos como gás, eletricidade, água, telecomunicações, entre outros, que foram alienados ao setor privado; a parcial deu-se com outros serviços públicos, como os carcerários, que passaram para firmas privadas mediante contratos (de gestão) com o governo. Em relação aos serviços públicos, educação e saúde, entre outros -porque considerados inapropriados para uma privatização em sentido estrito-, introduziu-se o conceito de quase-mercado. Willians, apud Sguissardi (2002, p.245-246)

O conceito de quase-mercado, conforme apontado anteriormente, foi cunhado por Le Grand. Para o autor, “quase-mercados são mercados porque substituem os provedores estatais por provedores independentes que atuam em competição. São quase porque se diferenciam de mercados convencionais em vários aspectos" (LE GRAND 1996, p.261). A competição entre os provedores se dá em função dos recursos públicos e dos contratos, a compra dos serviços ocorre através de vales e não por meios monetários e o consumidor é, por vezes, representado na escolha ou na compra do benefício por um terceiro (SILVA, 2001).

Para Afonso (2003), tal conceito põe em evidência o caráter híbrido das novas formas de financiamento, fornecimento e regulação de serviços públicos, antes de competência estritamente Estatal, mas que não resultam na diminuição do poder intervencionista desse mesmo Estado. 
Para Levacic (1995), a característica distintiva do quase-mercado para um serviço público é a separação do comprador, do vendedor e um elemento de escolha do usuário entre os vendedores. Aqui podemos considerar como comprador o Estado (por meio de seus representantes), como vendedor o gestor do serviço e o usuário é o cidadão. O autor sublinha em sua análise o alto grau de controle estatal sobre diferentes aspectos, como qualidade do serviço, investimentos, entrada de novos administradores e preço, que muitas vezes é zero para o usuário.

Para Whitty e Power (2002), quase-mercado seria o termo mais preciso para designar as políticas educacionais da Inglaterra, País de Gales, Estados Unidos e Nova Zelândia durante os anos de 1990. Para os autores, o quase-mercado se revelava, naquela situação, pela nova relação que se estabeleceu entre o ofertante do serviço, o "cliente" e o financiador.

O quase-mercado, portanto, traduz a nova configuração assumida pelo Estado. Em termos gerais, não se trata apenas de um movimento de expansão do mercado (e de seu ideário) e de retração do Estado, mas da interpenetração de ambos. (AFONSO, 1999).

Especificamente na educação, o conceito de quase-mercado ganhou uma importante dimensão e talvez tenha sido a área social em que sua aplicação fora mais percebida. Conforme apontam Sousa e Oliveira (2003), o quase-mercado educacional respondeu à impossibilidade da aplicação da abordagem típica da privatização e competição entre agentes econômicos livres e autônomos. Trata-se de um quadro aproximativo, em que alguns valores (e elementos) do mercado são utilizados. 
Não se trata, pois, de privatizar, transferir a oferta para o setor privado, mas de impor para educação pública uma combinação de mecanismos e idéias tendentes a imprimir uma lógica mercantil na sua gestão.

No campo educacional, as qualidades do mercado tiveram como importantes defensores Chubb e Moe (1990). A defesa dos autores deu-se pela via da valorização da eficácia do mercado em contraponto à ineficiência do Estado, tido como altamente burocrático e incapaz de resolver seus problemas - revelados no fracasso dos alunos.

Em uma análise sobre os resultados obtidos por alunos americanos de escolas públicas e privadas, Chubb e Moe (1990) revelaram que o problema da escola pública, tida como de pior qualidade, estaria na forma como ela estava organizada. "Nós acreditamos que as instituições existentes não podem resolver o problema, porque elas são o problema - e que a chave para melhores escolas é a reforma institucional” (p. 3).

Os autores alertavam, ainda, para o fato de que um dos problemas basilares da organização da escola pública americana era o controle democrático exercido pela sociedade sobre seus resultados. A solução seria substituir esse modelo pelo controle de mercado, capaz de conferir à escola maior eficácia, uma vez que possibilitava a ampliação de espaços de autonomia na própria escola.

Objetivos acadêmicos claros, liderança educacional forte, ensino profissionalizado, programas acadêmicos ambiciosos, organizações cooperativas, estas características das escolas eficazes são promovidas com muito maior sucesso pelo controlo do mercado do que pelo controlo democrático.

A autonomia burocrática e uma organização escolar eficaz são produtos naturais das forças institucionais básicas em ação nas escolas inseridas no mercado. Elas são o produto da competição escolar e das escolhas parentais. O sucesso está embutido na estrutura institucional da educação privada. Do modo como a educação pública está atualmente estruturada, as instituições tornam o sucesso quase antinatural (CHUBB e MOE, 1990, p. 182-183). 
Dessa proposta emerge um importante elemento que dá sustentação ao projeto de "mercantilização" dos processos educacionais, ou do quase-mercado educacional: a avaliação. É por meio da avaliação que o controle pelo mercado se concretiza, visto que seus resultados servem como referência para as escolhas parentais, impulsionam a competição entre as escolas e fazem surgir movimentos de mobilização no interior da escola cujo objetivo seria o de resolver, às suas próprias custas, problemas e deficiências detectados. A avaliação é, portanto, o elemento central da regulação estatal sobre a educação.

O termo regulação foi objeto de análise de diferentes autores da área educacional, como Barroso (2005), Oliveira e Silva (2007), Lessard (2006), entre outros. Todos concordam que o termo é polissêmico. "O conceito de regulação é passível de diferentes significados conforme o quadro teórico, disciplinar, lingüístico em que se inscreve" (OLIVEIRA E SILVA, 2007, p. 3).

Para Barroso (2005), o uso do termo "regulação" nos sistemas sociais sofre variações "conforme os contextos lingüísticos e administrativos dominantes" (p. 731).

No contexto francófono e em países onde predomina uma administração centralizada e burocrática,

a referência à "regulação" aparece como resultado de um certo efeito de moda (ou aggiornamento linguístico), com o fim de reforçar a imagem de um Estado menos prescritivo e regulamentador e de uma "nova administração pública" que substitui um controlo directo e $a$ priori sobre os processos, por um controlo remoto, e a posteriori baseado nos resultados. (BARROSO, 2005, p.732)

A ocorrência do conceito de regulação presente num contexto lingüístico anglo-saxônico e, principalmente, em países onde se verificaram mudanças políticas de cariz conservador e neoliberal, dá-se em oposição ao conceito de “desregulação". O autor destaca que 
Neste caso, a oposição regulação/desregulação, pretende sublinhar uma ruptura com os modelos "tradicionais" de intervenção do Estado na coordenação e pilotagem do sistema público de educação.

(...)

Nestes países o que está em causa não é uma simples alteração dos modos de regulação pelo Estado, mas a substituição parcial da regulação estatal por uma regulação de iniciativa privada através da criação de quase-mercados educacionais. (BARROSO, 2005, p.733)

O autor apresenta, também, uma análise sobre os novos modos de regulação das políticas educativas, tomando como referência uma investigação coordenada por ele que tinha por objetivo realizar um estudo comparado sobre a emergência de novos modos de regulação das políticas educativas e sua relação com os processos de produção local de desigualdades e segregação escolares. Foram analisados cinco países europeus: Bélgica, França, Hungria, Portugal e Reino Unido (Inglaterra e Gales).

Os resultados apresentados apontaram que as políticas dos países estudados tinham inspiração nos modelos pós-burocráticos e de Estado Avaliador ${ }^{3}$, cujo grau de intensidade das políticas e dosagem entre os diversos modelos mostraram-se muito variados. A Inglaterra destacou-se entre os demais paises por apresentar um maior controle central e adoção da lógica mercantil, em detrimento da intervenção local. Tal situação seria resultante da política intervencionista adotada no início da década de 1980 que, entre outras iniciativas, incitou a competição entre escolas e favoreceu a livre escolha dos pais, por meio da ampliação do mecanismo de avaliação externa e divulgação dos resultados às famílias.

\footnotetext{
${ }^{3}$ A partir da década de 1980, a centralidade dada à avaliação, sobretudo por governos neoconservadores e neoliberais de países centrais, começou a ser traduzido pela expressão "Estado Avaliador". A expressão "Estado Avaliador" é utilizada para explicar, em linhas gerais, que o Estado adotou um "ethos competitivo, decalcado no que tem vindo a ser designado por neodarwinismo social, passando a admitir a lógica do mercado com a importação para o domínio público de modelos de gestão privada cuja ênfase é posta nos resultados ou produtos dos sistemas educativos. No caso da educação, essa preocupação com o produto, mais do que com o processo, implica formas de avaliação específicas, como o retorno aos exames nacionais, à avaliação aferida ou a outras modalidades de avaliação externas"
}

(AFONSO 1999, p.157). 
Nos demais países tais incidências foram menos visíveis, embora a lógica mercantil tenha estado presente na gestão e prestação do serviço educativo.

Nesse contexto, a avaliação, entendida como pilar de sustentação dos processos de regulação estatal, teria a virtude de, por si, promover melhoras na qualidade dos serviços ao propiciar transparência e visibilidade da realidade, por meio dos resultados obtidos, o que forneceria elementos para a superação de problemas detectados (OLIVEIRA E SILVA, 2007).

Trata-se de uma avaliação estandardizada criterial, com publicação de resultados, conforme aponta Afonso (1999).

Essa modalidade de avaliação permite evidenciar, melhor que qualquer outra, o já designado "paradoxo do Estado neoliberal": por um lado, o Estado quer controlar mais de perto os resultados escolares e educacionais (tornando-se assim mais Estado, Estado-avaliador), mas, por outro, tem que partilhar esse escrutínio com os pais vistos agora como clientes ou consumidores (diluindo também por aí algumas fronteiras tradicionais, e tornando-se mais mercado e menos Estado). Produz-se assim um mecanismo de quase-mercado em que o Estado, não abrindo mão da imposição de determinados conteúdos e objetivos educacionais (de que a criação de um currículo nacional é apenas um exemplo), permite, ao mesmo tempo, que os resultados/produtos do sistema educativo sejam controlados pelo mercado (p.150).

A centralidade da avaliação, nesse contexto, colabora de forma

definitiva para que os processos de regulação se estabeleçam. O Estado reformado atua como agente de regulação das políticas educacionais - por meio da prescrição de normas e do controle sobre os resultados - e transfere a execução das tarefas (AFONSO, 1999). Por outro lado, ao tornar público os resultados da avaliação realizada, divide o controle com o mercado que, por meio de diferentes estratégias, responsabiliza as escolas por tais resultados.

Se Chubb e Moe foram, conforme apontado anteriormente, grandes defensores do mercado como modelo de eficiência e eficácia, além de proclamadores da 
necessidade da reformulação da escola pública como meio para melhora de sua qualidade, muitos foram os estudiosos da área educacional que denunciaram o caráter perverso do quase-mercado educacional (WHITTY E POWER,2002; AFONSO, 1998, 1999, 2003; SÁ, 2008; SOUSA,2001, 2003, entre outros).

Um aspecto relevante apontado pelos críticos das políticas de quasemercado educacional diz respeito à natureza das ações impostas. A competição, incitada pela divulgação dos resultados das avaliações a que as escolas são submetidas, é um exemplo dessas ações. Para Sousa (2001), a ênfase dada à competição traz para a educação escolar conseqüências de três ordens: 1) o agravamento da seletividade, 2) a prevalência da lógica produtivista e 3) a restrição à noção de direitos sociais.

A seletividade gerada pela competição pode ser facilmente percebida nas políticas educacionais baseadas na fórmula de quase-mercado que associam o financiamento estatal com os resultados das avaliações em larga escala.

Para Sá (2008, p.430-431), “a capacidade de produzir produtos de alta qualidade depende também da possibilidade de se selecionarem as melhores matériasprimas. Por isso, as escolas poderão sentir-se tentadas, senão mesmo obrigadas, a selecionar criteriosamente os seus alunos". Aqueles alunos que podem, de alguma forma, contribuir para os resultados nos testes são os mais desejados.

Em contrapartida, conforme asseveram Whitty e Power (2002),

$\mathrm{O}$ perfil do cliente menos desejado inclui aqueles com "menor habilidade", com necessidades educativas especiais e dificuldades específicas ao nível emocional e comportamental, assim como alunos pertencentes a famílias das classes trabalhadoras, a menos que esses tivessem algum dos atributos mais desejados (P.23).

A estratégia da implantação de mecanismo de seletividade na admissão dos alunos pode gerar resultados positivos nos processos de monitoramento 
(avaliações), dando a falsa impressão de que mudanças ocorreram, tanto do ponto de vista administrativo quanto pedagógico e, que consequentemente, houve melhora qualitativa. Trata-se de uma forma de burla ao controle do processo, que entendemos ser altamente prevista.

Em relação à prevalência da lógica produtivista, a competição colabora para o sucesso do processo na medida em que assume como natural e benéfica a aferição dos resultados ou dos produtos como meio de se demonstrar qualidade. Todavia, dois aspectos merecem ser analisados nesse contexto. O primeiro diz respeito ao referencial de qualidade que permeia tais avaliações, cujo caráter centralizado de definição propaga o alto grau de regulação estatal. A determinação dos padrões de desempenho esperados, ou o que será cobrado nas avaliações de larga escala, é tarefa dos órgãos centrais do governo - a despeito da necessária autonomia didática e pedagógica da escola -, o que tende a delimitar o conhecimento que deve ser legitimado pela escola ${ }^{4}$.

Uma segunda questão diz respeito ao fato de que ao enfatizar o produto, ou a produtividade - demonstrado pelos resultados avaliativos, índices de evasão e retenção -, desconsidera-se o processo e os fatores que interferem na sua construção. Assim, ao analisar os resultados finais, muitas vezes atribuindo prêmios ou distribuindo recursos às escolas melhores classificadas nos rankings, punem-se escolas cujas deficiências são legítimas e resultantes de sua estrutura e contexto e cuja melhora ou mudança depende, em grande medida, de apoio financeiro. Por esta lógica, as "piores" escolas tendem a sucumbir.

\footnotetext{
${ }^{4}$ A esse respeito consultar Sousa e Oliveira (2003).
} 
Importa destacar um movimento de naturalização da desigualdade, em detrimento de um projeto de escola pública universalista em termos de cobertura e qualidade.

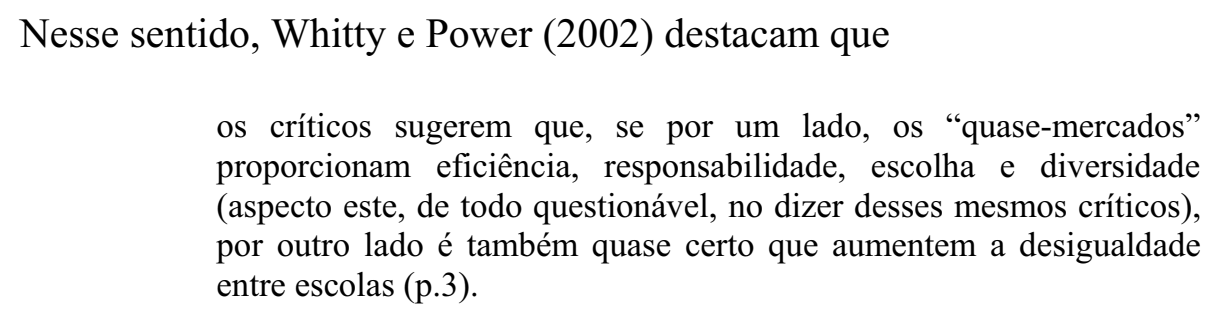

Nesse diapasão, ao se considerar natural a desigualdade, e consequentemente a exclusão, o direito social à educação também passa a ter relativizado seu alcance.

As políticas educacionais ao contemplarem em sua formulação e realização a comparação, a classificação e a seleção incorporam, conseqüentemente, como inerente aos seus resultados a exclusão, o que é incompatível com o direito de todos à educação.

A própria luta da população por fazer valer este direito tende a se fragilizar, prevalecendo a busca por conquistas individuais. (SOUSA, 2003, p. 188)

Parece-nos claro que as políticas educacionais em curso, comprometidas com o projeto de "mercadorização" da educação, produziram efeitos nefastos como a exclusão social, a seletividade e a naturalização da desigualdade. Tais efeitos põem em causa a educação como direito público, sugerindo, por vezes, que esta seja entendida como mercadoria ou bem privado.

O contexto ora apresentado serviu para demarcar, ainda que sucintamente, a trajetória das políticas de quase-mercado educacional. Importa destacar que a ênfase na análise da política educacional dos países centrais (aqui apresentada) e, em especial, da inglesa explica-se pelo fato de que optamos por entender suas origens.

É evidente que, a despeito das singularidades existentes, o quasemercado educacional tem se caracterizado como tendência hegemônica nas políticas 
educacionais tanto de paises desenvolvidos, quanto de economias periféricas. É evidente também que tais políticas se inserem no amplo contexto de reestruturação da gestão do Estado. Assim, cabe compreender tal contexto.

\subsection{A reforma do Estado e a emergência do mercado}

O recente processo reformista dos Estados Nacionais tem sido explicado basicamente como conseqüência de crises financeiras.

Nos países centrais tal processo começa a ocorrer em meados dos anos de 1970 e se justifica pelo esgotamento do modelo de Estado Benfeitor aliado à crise do petróleo, considerada uma das causas da recessão econômica (BIANCHETTI, 2005, p.29).

Para Martins (2004), a crise do Estado obedecia a um padrão, caracterizado pela presença de pontos recorrentes que se interrelacionavam em diferentes medidas:

a) fim do desenvolvimentismo pós-guerra, pelo fim de Bretton Woods, as crises do petróleo, as crises de liquidez e a instabilidade do mercado financeiro internacional, os novos requisitos de integração competitiva da globalização etc.; b) crise do welfare state keynesiano, pelas disfunções e desvantagens da intervenção estatal na garantia do bem-estar ou da estabilidade econômica, relativa-mente aos atributos do mercado, conforme defendido pelas correntes de inclinação neoliberal a partir dos anos $70 ;$ c) disfunções burocráticas ou crise do modo de implementação estatal de serviços públicos; e, dentre outras, d) ingovernabilidade: sobrecarga fiscal, excesso de demandas e crise de legitimidade. (p.6)

$\mathrm{Na}$ América Latina a crise foi atribuída ao modelo desenvolvimentista

vigente, ao endividamento interno e externo e à mundialização do capital. Tal cenário foi decisivo para o espraiamento do ideário neoliberal, cuja responsabilidade pela disseminação, conforme destaca Fiori (2003), foi das agências financiadoras 
internacionais que, em troca da renegociação de dívidas desses países, prescreveu uma série de políticas liberalizantes oriundas do chamado Consenso de Washington ${ }^{5}$.

Bresser Pereira (2003) indica que de acordo com a "abordagem de Washington" (p. 249 ) as causas da crise latino-americana eram duas:

1) o excessivo crescimento do Estado, representado pelo protecionismo - identificado com o modelo substitutivo de importações -, pela excessiva regulação e por empresas estatais ineficientes e numerosas;

2) o populismo econômico, identificado com a incapacidade de os governos controlarem o déficit público e manterem sob controle as demandas salariais, tanto no setor privado como no setor público. (BRESSER PEREIRA, 2003, p. 249)

Os diagnósticos da crise aqui apresentados, ambos de matriz neoliberal, têm como ponto comum a crença de que sua origem está no Estado, principalmente no colapso no padrão de financiamento público do Estado-Providência, decorrente do continuado déficit público. (LIMA, 2007)

Todavia, tal constatação, lembra o autor, não leva em conta que tal colapso estaria associado, também, ao financiamento do setor privado "que funciona como alavanca da reprodução do capital, e não só da produção de bens sociais públicos, como é sistematicamente lembrado pelos neoliberais" (LIMA, 2007, p.29).

Há que se ressaltar, no caso das economias latino-americanas, que o déficit público era resultante, em grande parte, do volume da dívida externa.

\footnotetext{
${ }^{5}$ O termo "Consenso de Washington" foi cunhado por John Williamson em 1989. Em palestra proferida em agosto de 2003 na Faculdade Álvares Penteado, Williamson afirmou que o termo (ou frase) apresentava três significados: i) o seu significado original: uma lista de 10 reformas específicas que quase todo o mundo em Washington acreditava necessárias em quase todos os países da América Latina, ii) $\mathrm{O}$ programa das organizações internacionais sediadas em Washington, principalmente o Banco Mundial e o FMI, para seus países clientes, iii) "Um programa de neoliberalismo, o fundamentalismo do mercado, que aparentemente a esquerda acredita que as instituições internacionais estão dedicadas a impor aos países em desenvolvimento". (Williamson, J. 2003)
} 
A despeito das reais causas da crise financeira a que os países estavam submetidos (tanto os centrais quanto os periféricos), assim como da imprecisão e das omissões dos diagnósticos realizados acerca de sua origem, medidas foram propostas, aqui e ali, no intento de reformular política e economicamente o Estado como única forma de se solucionar o problema da crise, uma vez que para a teoria neoliberal não é o capitalismo que está em crise, mas o Estado.

Mais especificamente no que tange às propostas de ajustamento dos países latino-americanos, importa lembrar que, se por um lado elas originaram-se de organizações externas sediadas nos países centrais (e que obviamente representavam o pensamento desses países), por outro não se pode desconsiderar que a adesão à tais propostas, em maior ou menor escala, passava por uma decisão dos países envolvidos.

Nessa perspectiva, Santos (2002) destaca:

O Consenso de Washington é uma decisão política dos Estados centrais como são políticas as decisões dos Estados que o adoptaram com mais ou menos autonomia, com mais ou menos selectividade. Não podemos esquecer que, em grande medida, e sobretudo ao nível económico e político, a globalização hegemónica é um produto de decisões dos Estados nacionais. A desregulamentação da economia, por exemplo, tem sido um acto eminentemente político. A prova disso mesmo está na diversidade das respostas dos Estados nacionais às pressões políticas decorrentes do Consenso de Washington. O facto de as decisões políticas terem sido, em geral, convergentes, tomadas durante um período de tempo curto, e de muitos Estados não terem tido alternativa para decidirem de modo diferente, não elimina o carácter político das decisões, apenas desloca o centro e o processo político destas. (p.17)

Conforme sublinha o autor, a adesão às recomendações do chamado

Consenso de Washington constitui-se numa decisão política que, por sua própria natureza, define a concepção de Estado - e dos papéis que este deve desempenhar daqueles envolvidos no processo. Não se trata apenas e simplesmente de uma aceitação irrestrita, por ser inevitável, tampouco resignada. Não fazer, também é fazer. 
Segundo Portela Filho (1994), nos anos de 1980 as recomendações ${ }^{6}$ do Consenso de Washington para o ajustamento da América Latina pareciam tomar por base três premissas:

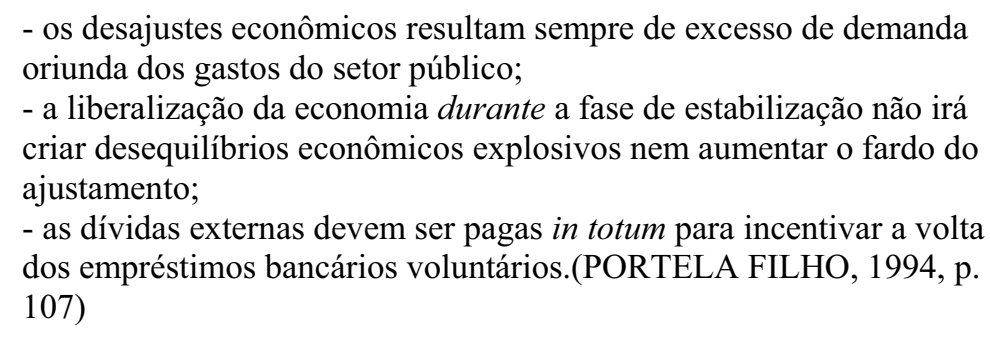

Para o autor, os países devedores latino-americanos foram

“encorajados" a tentar realizar simultaneamente a estabilização, a liberalização e o pagamento total das dívidas. Tal tarefa, além de difícil execução, exigia a implantação de um conjunto de ações visando reduzir o déficit do balanço de pagamento (contendo a demanda interna), cortar ao meio o financiamento do setor público e liberalizar a economia, via abolição ou diminuição do controle de preços (com exceção do preço da mão-de-obra ${ }^{7}$.

Os anos de 1990 marcaram, portanto, o início da implementação dos programas de ajustamento dos países latino-americanos balizados pelos ditames do centro capitalista. Tratou-se de um processo profundo que exigiu a reformulação do papel que o Estado deveria desempenhar a partir de então.

Sinteticamente, podemos considerar que o conteúdo das reformas implementadas tinha o mercado como referência. Para Chauí (1999),

\footnotetext{
${ }^{6}$ Disciplina fiscal, reordenamento nas prioridades dos gastos públicos, reforma tributária, liberalização do setor financeiro, manutenção de taxas juros competitivas, liberalização comercial, atração de investimentos diretos estrangeiros, privatização das empresas estatais, desregulamentação da economia e proteção aos direitos autorais (SILVA, 2002, p. 26)

${ }^{7} \mathrm{O}$ arrocho salarial é incluído na maioria dos programas de ajustamento, ainda que de forma muito discreta, mas firme. Há a crença de que as contenções salariais possibilitam queda mais rápida da inflação e aumento de competitividade das exportações (PORTELA FILHO, 1994, p.108)
} 
A Reforma tem um pressuposto ideológico básico: o mercado é portador de racionalidade sociopolítica e agente principal do bemestar da República. Esse pressuposto leva a colocar direitos sociais (como a saúde, a educação e a cultura) no setor de serviços definidos pelo mercado. Dessa maneira, a Reforma encolhe o espaço público democrático dos direitos e amplia o espaço privado não só ali onde isso seria previsível - nas atividades ligadas à produção econômica -, mas também onde não é admissível - no campo dos direitos sociais conquistados (1999, s.p.)

Conforme anteriormente apontado, o Estado estava em crise, cuja causa residia na crise fiscal. A crise fiscal, por sua vez, resultava, entre outras questões, do excessivo gasto governamental com as políticas de atendimento social.

Para Oliveira,

alguns estudos vêm demonstrando que as reformas de Estado ocorridas nos anos 90 nos países latino-americanos trazem uma orientação mais ou menos convergente com o modelo britânico de reforma implantado no período thatcheriano. Em tais reformas percebe-se como traço comum a preocupação em reduzir os gastos públicos destinados à proteção social, principalmente dos pobres, e a priorização da assistência social aos mais pobres, sobretudo a partir de fundos públicos criados para este fim, com existência provisória. (2006, p.93)

Importa destacar que tal processo - redução dos gastos públicos destinados à proteção social -, se dá por meio de estratégias que visam convencer a população da necessidade de impor critérios mais eficientes de distribuição de benefícios sociais. Assim, as mazelas da gestão pública são evidenciadas e apresentadas como causadoras dos desajustes e desigualdades do setor. Esse é o pano de fundo para que o mercado seja apontado como único capaz de superar as falhas do Estado, seja por meio da sua atuação direta, seja pela adoção de sua lógica na gestão estatal.

Assim, a reforma do Estado se orientou pela diminuição de sua atuação - no que tange a oferta de diversos serviços - e supervalorização do mercado, visto como modelo de eficiência e eficácia. 
Em relação às políticas sociais, foram impostas ações que culminaram na transferência de sua oferta e/ou financiamento para o mercado, via privatização. Nas áreas em que tal tarefa não pode se concretizar, dadas as peculiaridades dos serviços prestados, introduziram-se mecanismos de mercado na sua gestão.

Uma das características das políticas neoliberais tem sido a promoção de mecanismos de mercado no interior do espaço estrutural do Estado, liberalizando e promovendo pressões competitivas entre serviços, transformando os utentes em clientes, privatizando, adoptando instrumentos e princípios de gestão baseados na racionalidade instrumental e subordinando os direitos sociais às lógicas da eficácia e da eficiência (AFONSO, 2003, p.39).

Destaca-se, nessa perspectiva mercantil de reforma do Estado, a emergência de mecanismos de incentivo a concorrência, seja no âmbito estatal (entre diferentes setores), ou do Estado com setores privados. Tal concorrência é percebida tanto na busca pelos recursos públicos, quanto por meio da nova lógica organizacional implantada. (PERONI e ADRIÃO, 2004)

É importante lembrar que nem todos os setores públicos foram privatizados. Para algumas instituições públicas, a introdução de concepções de gestão privada foi a alternativa encontrada, uma vez que não foi alterada a propriedade das mesmas. E é essa perspectiva de gestão dos serviços sociais orientada pelo mercado que denominou-se quase-mercado. (PERONI e ADRIÃO, 2004)

Como visto na seção anterior, o conceito quase-mercado foi cunhado por Le Grand ao analisar as especificidades da política social inglesa implementada durante o governo de Margareth Thatcher.

Uma característica que distingue os quase-mercados dos mercados clássicos é a ausência da livre concorrência. Trata-se de uma variação que conjuga competição e regulação simultaneamente. 
Para Santomé,

O "quase mercado" perante um serviço público caracterizar-se-ia por uma separação entre aqueles que produzem um serviço, aqueles que o escolhem e aqueles que o financiam e controlam. Esta separação permite que possam competir para oferecer determinado serviço tanto sectores privados como públicos. Uma das peculiaridades dos "quase mercados" é, todavia, o importante grau de controlo que mantêm o Estado ou o governo das Comunidades Autónomas em aspectos de grande importância como são o financiamento desses serviços, a sua inspecção, a imposição de trabalhar determinados conteúdos, o tempo que assistirão os seus usuários e usuárias, o preço máximo que é permitido cobrar, a capacidade para determinar os que podem oferecer estes serviços e de que formação precisam os que trabalham nessas instituições (2001, p.64).

Duas questões merecem destaque na análise do quase-mercado. A primeira diz respeito à sua própria configuração, cujas relações entre oferta e procura se distanciam dos modelos clássicos do mercado de livre concorrência. Do ponto de vista da oferta, as instituições ofertantes (aqui representadas pelo setor público) não têm como objetivo máximo o aumento dos benefícios econômicos de seus proprietários. Os objetivos são, conforme indica Santomé (2001) "mais de caráter social, de ajuda ao desenvolvimento das pessoas, de socializar em determinados valores, de promover determinadas concepções da vida; a idéia de negócio para acumular mais capital econômico, não aparece nunca à primeira vista" (p.65). Do ponto de vista das escolhas (ou procura), por sua vez, estas se dão não em função dos custos econômicos, mas dos aspectos organizativos, dos resultados qualitativos demonstrados. No caso da educação, por exemplo, as escolhas tendem a levar em conta as concepções educativas de determinadas escolas, seus ideários, as expectativas dos pais em relação ao rendimento de seus filhos, o modelo de disciplina, o tipo de estudantes atendidos.

Uma segunda questão a ser analisada é o grau de controle e regulação assumido pelo Estado nessa perspectiva de quase-mercado. Trata-se de outro fator 
distintivo que se manifesta, principalmente, no caráter prescritivo de atuação do Estado, nos mecanismos de avaliação dos serviços prestados, na imposição de regras de atuação.

$\mathrm{Na}$ área educacional ficam mais evidentes os contornos do quasemercado como opção política das recentes reformas implantadas. Nesse sentido, e sendo a educação o objeto de nossas análises, apresentaremos na próxima seção aspectos da reforma educacional no contexto da reforma do Estado. Evidenciaremos as reformas ocorridas no Brasil e abordaremos a emergência do paradigma do mercado nesse processo.

\subsection{A reforma educacional brasileira no contexto da reforma de Estado: mercado e quase-mercado}

O processo de reforma do Estado brasileiro iniciado em meados da década de 1990, insere-se, conforme anteriormente indicado, num projeto amplo de ajustamento das economias latino-americanas aos ditames do centro capitalista, referenciados no Consenso de Washington.

No Brasil, podemos considerar como marco do processo reformista de matriz neoliberal o governo Fernando Collor de Mello (1990-1992). Collor promoveu a abertura da economia ao mercado internacional, suprimindo as barreiras alfandegárias. Impôs, ainda, um programa de privatização e de desmonte do Estado, sob a alegação da necessidade de combate a inflação. Nessa esteira, lançou o programa de reestruturação produtiva, enfatizando a gestão pela qualidade e pela produtividade (MAGNANI, [s.d.]). 
Itamar Franco (1992-1994), substituto de Collor após seu Impeachment, não promoveu reformas estruturais durante seu governo, embora tenha criado condições para que elas pudessem acontecer no futuro.

No governo subseqüente, Fernando Henrique Cardoso (1995-2002) manteve a mesma agenda iniciada por Collor.

O Brasil (...) acentua seu ajuste estrutural, inserindo-se na Nova Ordem Mundial apenas na década de 1990. Com a legitimidade política e eleitoral, e em um clima de hiperpresidencialismo, o presidente Fernando Henrique Cardoso transforma o Brasil no país das reformas e o submete, apesar de suas peculiaridades, ao figurino do capital, desenhado, agora, pelos organismos multilaterais, com especial destaque para o Banco Mundial. (SILVA JR, 2003, p. 88)

Com um programa de ajustes melhor delineado, o novo governo promoveu a Reforma do Estado perseguindo dois objetivos principais: a transformação do padrão de atuação do Estado na economia e a mudança no funcionamento da administração pública (MATTOS, 2006).

No que tange à transformação do padrão de atuação do Estado, buscou-se a redução de sua intervenção direta na atividade econômica, por meio de uma nova dinâmica que atribuía ao Estado um papel de planejamento e regulação. Em relação à mudança no funcionamento da administração pública, buscava-se, com tal transformação, aumentar sua eficiência.

$\mathrm{Na}$ sua formulação original, consubstanciada no Plano Diretor da Reforma do Aparelho do Estado (PDRE), esse objetivo seria perseguido em grande medida por meio da implementação da chamada "reforma gerencial" da administração pública, bem como por meio da reforma do regime dos servidores públicos. (MATTOS, 2006, p.10)

Pode-se inferir, a partir das análises sobre a temática, que o conteúdo da reforma do Estado brasileiro sintetiza-se na promoção de quatro grandes 
mecanismos: a descentralização das atividades "classicamente" desempenhadas pelo Estado, a concentração de mecanismos de controle, a privatização e a desregulamentação das relações sociais.

Vale destacar que os elementos da reforma do Estado foram expressos e consubstanciados no Plano Diretor da Reforma do Aparelho do Estado. Passaremos a apresentar a seguir algumas considerações a esse respeito.

O Plano Diretor da Reforma do Aparelho do Estado foi elaborado pelo extinto Ministério da Administração Federal da Reforma do Estado (MARE), cujo comando encontrava-se nas mãos do então Ministro Luiz Carlos Bresser Pereira. Tal documento foi aprovado em 21/09/1995 pela Câmara de Reforma do Estado ${ }^{8}$. Na sua apresentação, o Plano trazia uma análise do então presidente da república a respeito da necessidade de se reformar o Estado, visto que esse se encontrava em crise, cujo diagnóstico apontava para o esgotamento do modelo de atuação do próprio Estado, o que gerava a deterioração dos serviços sociais e agravava a crise fiscal e a inflação. Buscava-se, segundo o presidente, a reconstrução da administração pública em bases modernas e racionais.

É preciso, agora, dar um salto adiante, no sentido de uma administração pública que chamaria de "gerencial", baseada em conceitos atuais de administração e eficiência, voltada para o controle dos resultados e descentralizada para poder chegar ao cidadão, que, numa sociedade democrática, é quem dá legitimidade às instituições e que, portanto, se torna "cliente privilegiado" dos serviços prestados pelo Estado. (BRASIL, 1995, p.7)

O tom do discurso era o da promoção do consenso, para tanto apresentava dados que visavam legitimar a proposta apresentada. Evocava-se a

\footnotetext{
${ }^{8}$ Câmara de Reforma do Estado - composta pelo Ministro de Administração e Reforma do Estado (Bresser Pereira), pelos Ministros do trabalho, Fazenda e do Planejamento e Orçamento e pelo Ministro Chefe do Estado-maior das Forças Armadas.
} 
necessidade de reorganização das estruturas administrativas como meio para promoção da qualidade e produtividade dos serviços prestados.

Por fim, interessa destacar que, embora o Plano Diretor da Reforma do Aparelho do Estado constitua-se no documento base das ações reformistas do governo FHC, tal processo já havia se iniciado. Esse aspecto fica evidente quando, ainda na apresentação do documento, o presidente destaca as propostas de emenda constitucional apresentadas ao Congresso Nacional para as reformas administrativas e previdenciária. Adiantando possíveis resistências de setores sociais que seriam afetados pelas reformas, o presidente finaliza afirmando que a população apoiava a reforma do Estado e que os servidores públicos também deveriam fazê-lo, já que,

os bons funcionários, que constituem a maioria absoluta, nada têm a temer. Muito pelo contrário: pretende-se valorizar o servidor público, propiciando-lhe motivação profissional, remuneração condizente com o mercado de trabalho nacional, além de razoável segurança no emprego. Só assim será restaurada a criatividade, a responsabilidade e a dignidade do servidor público, cuja aspiração maior deve ser a de bem servir a população. (BRASIL, 1995, p. 7-8)

No documento evidencia-se a necessidade de redefinição do papel do Estado, que deveria deixar de ser responsável direto pelo "desenvolvimento econômico e social pela via da produção de bens e serviços, para fortalecer-se na função de promotor e regulador desse desenvolvimento".

Aspectos como a publicização, a descentralização, a privatização foram valorizados no processo de reforma e revelaram a concepção e o ideário de Estado perseguido. Tais elementos constituem a base da desresponsabilização do Estado reformado para com os serviços sociais. De uma forma ou de outra, serviços sociais foram transferidos, terceirizados, privatizados em nome da eficiência administrativa. Contudo vale lembra que, nos casos em que não foi possível a adoção de tais 
mecanismos, elementos típicos de mercado foram introduzidos na gestão dos serviços que continuaram a ser promovidos pelo Estado, como a educação e a saúde.

Para Sguissardi (2005), a reforma do aparelho do Estado foi uma reforma "pós-burocrática, declaradamente gerencialista, apoiada em concepções de Estado subsidiário, avaliador e controlador"'(p. 212).

O governo de Luis Inácio Lula da Silva, iniciado em 2003, manteve a agenda reformista dos governos que o antecederam. Embora historicamente reconhecido como opositor das políticas praticadas por seus antecessores, Lula fez a opção não apenas pela continuidade, mas pelo aprofundamento de um projeto de desenvolvimento de corte neoliberal.

O compromisso com o pagamento da dívida externa e a manutenção dos acordos anteriormente firmados com os organismos internacionais de financiamento são modelares da postura assumida pelo atual governo.

Conforme aponta Davies (2004), em um estudo realizado após um ano do governo Lula, "as políticas do Governo Lula têm priorizado até agora a geração de superávit fiscal para pagar os juros da dívida externa e interna e, assim, atender aos capitalistas financeiros externos e internos, em nada diferindo do Governo FHC'. (Davies, 2004, p. 246). Para o autor, dada a prioridade estabelecida, não surpreende a obsessão

no congelamento ou redução dos gastos sociais (porém não os financeiros!) por parte do Governo Lula e, portanto, a busca ou a intensificação de parcerias com o setor privado em todas as áreas, inclusive na educacional, como a renúncia fiscal e a proposta de fim da gratuidade do ensino superior público (DAVIES, 2004, p. 246). 
De modo geral, pode-se inferir que o projeto de reforma do Estado não se concretizou em definitivo. Ou melhor, tal projeto exige medidas a longo prazo, cujos resultados práticos, postos em termos de ações concretas, reverberam de governo em governo. Ao atual coube a tarefa de manter acordos financeiros e cumprir obrigações ligadas ao pagamento da dívida externa, contudo, foi na área social que as principais ações foram percebidas. Exemplo disso foi a ênfase dada no papel regulador do Estado em relação aos serviços sociais, a ampliação de estratégias de descentralização, privatização e publicização desses serviços, num nítido compromisso de se manter um Estado limitado na sua atuação, fortemente regulador, e aberto às investidas do mercado.

Cumpre destacar que a expansão do mercado e de sua lógica nas reformas do Estado, assim como a introjeção da racionalidade mercantil na esfera pública, conforme destaca Silva Jr (2003), são fruto da imposição gerada pela universalização do capitalismo e divisão planetária em megablocos econômicos. Para o autor,

na transição do fordismo para o presente momento histórico do capitalismo mundial, o Estado de bem-estar social dá lugar a um Estado gestor, que carrega em si a racionalidade empresarial das corporações transnacionais, tornando-se, agora, as teorias organizacionais, antes restritas aos muros das fábricas, as verdadeiras teorias políticas do Estado moderno. (SILVA JR, 2003, p.88)

E complementa,

A inserção do Brasil nesse processo provoca também uma transformação no aparelho de Estado, que de interventor e estruturador da economia em favor do capital nacional e internacional, desde a década de 1930, passa na década de 1990 a um Estado modernizado, a um Estado gestor voltado para a reprodução do capital e de elaboração de políticas sociais a serem desenvolvidas no âmbito da sociedade civil, ainda que sob seu controle e avaliação. (SILVA JR, 2003, p.88) 
A reforma educacional insere-se, portanto, nesse contexto mais amplo de reforma do Estado.

As décadas de 1980 e 1990 foram marcadas por uma profunda discussão em torno da necessidade de reforma nas estruturas e funções dos sistemas de ensino, no currículo e na formação dos profissionais da educação (MARTINS, 2001, p. 30). A necessidade de tais reformas foi justificada pela idéia de que deveria haver o necessário ajuste dessas às reformas econômicas, como meio de geração de benefícios sociais e redução da pobreza.

Há cerca de uma década, iniciou-se um movimento internacional de reforma da educação que alegadamente daria condições aos sistemas educacionais de cada um dos paises para enfrentar os desafios de uma nova ordem econômica mundial. No caso da América Latina, indicava-se também a necessidade de se conciliar os desafios da modernidade sem aumento da exclusão, como reação aos problemas estruturais que apresenta o desenvolvimento capitalista (KRAWCZYK et al, 2001, p. 02).

A educação passou a ser encarada pelos organismos internacionais financiadores, principais mentores das reformas do ensino das últimas décadas, como responsável pelo crescimento econômico e redução da pobreza. Nesse sentido, a educação básica - entenda-se, nesse contexto, ensino fundamental-, passou a ser o foco das políticas das agências financiadoras internacionais, pois era vista como aquela capaz de proporcionar maior retorno social, uma vez que ajudava a resolver problemas como o controle de natalidade, altos índices de crescimento demográfico, saúde, preparo da mulher para o mundo produtivo, entre outros, considerados entraves para o desenvolvimento dos países de baixa e média renda.

A educação, especialmente a educação básica (primária e secundária de primeiro ciclo), contribue para reduzir a pobreza ao aumentar a produtividade dos pobres, reduzir a fecundidade e melhorar a saúde, e 
dotar as pessoas das atitudes que necessitam para participar plenamente na economía e na sociedade (BANCO MUNDIAL, 1996, p.01)

Os principais desafios que deveriam ser vencidos por meio da reforma eram: o aumento do acesso a educação, a melhoria da equidade e a elevação da qualidade. Porém, o principal entrave detectado era a forma como estavam organizados os sistemas de ensino, tanto administrativa como financeiramente. Do ponto de vista administrativo, os sistemas de ensino deveriam ser mais eficientes, para tanto necessitavam de certa flexibilidade e descentralização. Financeiramente, era preciso que houvesse uma maior eficiência nos gastos, aumento de receitas dos governos, além da necessidade de se buscar novas fontes de financiamento.

Todavia, as razões implícitas no processo eram: a racionalidade, a economia e a construção do caminho para a privatização. Nessa ótica, conceitos como modernização gerencial, desconcentração do poder, gestão democrática, fortalecimento da sociedade civil, liberdade financeira, administrativa e pedagógica, entre outros tantos, passaram a servir para neutralizar possíveis resistências (visto que vinham ligados a discursos cuidadosamente construídos) e legitimar estratégias de controle e intervenção.

As mudanças nas estruturas dos sistemas, como foi visto anteriormente, deram-se em função de um projeto de reforma educacional imposto. Suas estratégias e ações, via de regra, apresentaram-se isentas de preocupações com a identidade e a realidade contextual das localidades onde eram implementadas.

Além do caráter homogeneizante das reformas (KRAWCZYK et al, 2001, p. 06), a análise de seus resultados, na mesma medida, era única, preponderantemente focada em índices quantitativos e necessariamente centralizada. 
Acreditava-se que apenas por intermédio desse controle haveria possibilidade de reversão nos baixos índices de qualidade apresentados, aumentando as taxas de retorno da educação (MARTINS, 2001, p. 31).

É inegável que há uma legitimidade no controle do Estado sobre a implementação de suas políticas setoriais, por meio da avaliação dos processos e dos impactos dos programas governamentais. Porém, é necessário que essa legitimidade seja vista no âmbito das relações complexas existentes entre a sociedade civil - instância à qual as escolas deveriam prestar contas efetivamente do que fazem com a escolaridade de jovens e crianças - e o Estado, a quem compete prover o sistema de ensino de condições adequadas para que os programas de governo sejam operacionalizados. De qualquer forma, a emergência do conceito de accountability nos anos 60 e sua consolidação a partir, sobretudo, dos anos 80 , evidenciaram que a avaliação assumiu o lugar central na implementação das políticas sociais (MARTINS, 2001, P.31).

As políticas reformistas, contudo, foram apresentadas e difundidas sob

forma de diretrizes que serviram para "orientar" as ações de diversos países - com

diferentes realidades - e impuseram uma mudança de paradigma na gestão do ensino.

A reforma educacional brasileira, na esteira das reformas educacionais

latino-americanas, cumpriu objetivos e metas externamente estabelecidos. Os

ajustamentos dos sistemas educativos foram promovidos tendo em conta a mudança no

paradigma de gestão, numa perspectiva de aproximação ao modelo gerencial, bem em sintonia com o conteúdo da reforma do Estado.

A tentativa por parte do Estado de capitanear o processo de mudanças na educação, que ocorre na década de 90, será fundada no discurso da técnica e na agilidade administrativa. Para tanto, as reformas implementadas na educação no período mencionado serão implantadas de forma gradativa, difusa e segmentada, porém com rapidez surpreendente e com mesma orientação. A lógica assumida pelas reformas estruturais que a educação pública vai viver no Brasil em todos os âmbitos (administrativo, financeiro, pedagógico) e níveis (básica e superior) tem um mesmo vetor. Os conceitos de produtividade, eficácia, excelência e eficiência serão importados das teorias administrativas para as teorias pedagógicas. (OLIVEIRA, 2006, p.3) 
A reafirmação do mercado como modelo de eficiência e eficácia, encontrou na reforma educacional brasileira campo fértil. A gestão da educação brasileira, sob responsabilidade do Estado, carecia de reformulações. A crença na eficácia privada, em contraponto com a ineficiência do Estado, propiciou a abertura de espaços que culminaram no

surgimento de novos modelos empresariais provedores de serviços educacionais com fins lucrativos (for profit) orientados pelo mercado, as universidades corporativas, escolas e universidades virtuais, os consórcios de instituições públicas e empresas privadas, as escolas autogestionadas e a franchising educacional. (grifo nosso) (CAMARGO, et al, 2003, p. 728)

Se por um lado a emergência do mercado na reforma educacional brasileira se materializou sob forma de transferência de determinados serviços ao setor privado, ou pelo afrouxamento dos critérios de concessão de autorização de criação e abertura de escolas privadas, por outro, ela se configurou no emprego de alguns mecanismos distintivos do mercado. Exemplo disso é a ênfase dada à avaliação educacional.

Assim como apontado anteriormente na análise de reformas educacionais de outros países, a avaliação educacional ganhou na reforma educacional brasileira uma dimensão fundamental. Surgiu como uma estratégia importante de fomento de novas formas "gerenciais", principalmente no interior das escolas. A avaliação foi (e tem sido) apresentada e justificada como propulsora de "qualidade", substituindo a "idéia força" da "igualdade" como principal objetivo das políticas educacionais (Gentili e Silva, 1995).

Os argumentos que justificaram a introdução da avaliação educacional enfatizavam e valorizavam seu uso como importante instrumento de controle de resultados pelo Estado, estabelecimento de parâmetros para comparação e classificação 
das escolas, estímulo à escola e ao aluno por meio da premiação e a possibilidade de controle público do desempenho do sistema escolar. Tais argumentos expressavam a nova concepção de Estado na condução das políticas educacionais (SOUSA, 2003)

De modo geral, conforme apontam Sousa e Oliveira (2003 p.188) "a noção de educação como direito é reduzida à condição de mercadoria, administrada com uma lógica produtivista e sob o pressuposto de padrões diferenciados de qualidade de ensino".

A mercadorização da educação, nesse contexto, traduzir-se-ia na introdução de elementos do mercado no sistema educativo como a utilização dos resultados dos testes como meio para alocação de recursos e responsabilização dos professores e escolas pelos resultados. Para Cookson (apud AFONSO, 1998), essa ideologia de mercado como modelo de regulação tende a criar uma maior estratificação em termos de classe, raça e gênero.

Contudo, ao pensarmos na ideologia de mercado ou na introdução de elementos de mercado no sistema educativo, devemos considerar que não se trata de um mercado nos moldes clássicos, cuja concorrência é livre e o Estado é apenas o garante dos contratos e acordos. "Quando se fala de mercadorização da educação não se trata senão da implementação de mecanismos de liberalização no interior do sistema educativo, ou da introdução de elementos de quase-mercado". (AFONSO, 1999, p. 144).

Para Afonso (1999, p139), a questão da "revalorização da ideologia de mercado" estaria ligada à redefinição do papel do Estado, ambas vistas como vetores do processo de reformulação de políticas educativas. 
Pode-se inferir que as políticas educacionais assentadas na lógica de mercado e mais especificamente orientadas pela valorização da avaliação como importante estratégia de gestão, tendem a produzir profundas exclusões, uma vez que tomam como natural a diferenciação qualitativa entre escolas, ao mesmo tempo em que aceitam a "seleção" de clientes que podem contribuir para a melhoria da perfomance das escolas nas avaliações educacionais.

Sousa e Oliveira (2003) destacam que

A crença é a de que as pressões geradas pela competição, suscitada pelos procedimentos avaliativos, farão com que sejam mobilizados processos e recursos que resultarão em melhoria da qualidade de ensino. Desse modo, pressupõe-se a aceitação da desigualdade como condição mesma de produção de qualidade, pois sendo diferentes e diversificadas as condições dos sistemas e unidades escolares estaríamos caminhando na direção de intensificar os processos de segregação e seleção educacional e social (p. 890).

Muitas são as evidências da presença do mercado nas reformas educacionais brasileiras. Tanto em seu estado "puro", quanto em sua forma mitigada, o mercado é tido como modelo a ser perseguido, seja em função de sua "decantada" qualidade, seja por seus mecanismos de funcionamento que emprestam à educação pública uma dinâmica mais flexível e assente na proposta de racionalização e novas formas de gestão.

A versão mitigada de mercado a que nos referimos é o quase-mercado, já abordado em seções anteriores. É uma outra versão daquilo que entendemos como mercado, numa perspectiva que analisa suas formas de atuação e seus objetivos. Tal explicação se justifica pelo fato de que os quase-mercados surgiram na esteira de uma nova configuração de Estado e de sociedade, que produziram formas distintas de relação entre Mercado e Estado (Público e Privado), Estado e Sociedade (Público e Público 
não-Estatal) e Mercado e Sociedade (Privado e Público não-Estatal). Tais relações serão abordadas no capítulo seguinte. 


\section{CAPÍTULO 2}

QUASE-MERCADO E A PARTICIPAÇÃO DO PÚBLICO NÃO-ESTATAL NA EDUCAÇÃO 


\subsection{Público, Privado e Público não Estatal: articulações em torno da oferta dos serviços educacionais}

A reforma do Estado no Brasil, iniciada na década de 1990, foi (e tem sido) o marco referencial das políticas educacionais em curso.

Assentado em premissas de modernização, racionalização e privatização, o processo de reforma do Estado no Brasil tinha o mercado como modelo de racionalidade sóciopolítica conservadora e configurou-se pela minimização do Estado no tocante às políticas sociais (DOURADO, 2001, p.49).

A concretização da reforma se deu pela imposição de um modelo de Estado gerencial que buscava responder, segundo seus propositores, às exigências do mercado internacional, promovendo no país os devidos ajustamentos requeridos pelo modelo econômico.

A reforma educacional, portanto, tem sua gênese na reforma do Estado e dessa forma orienta-se pelos mesmos referenciais: produtividade, eficácia, eficiência e qualidade (típicos das organizações de mercado).

Interessa lembrar que os movimentos de reforma que acometeram a educação brasileira também estiveram presentes em outros países e, a despeito de algumas particularidades, ocorreram seguindo certa tendência, qual seja: desdobraramse de reformas mais amplas e abrangentes e, na maioria dos casos, em resposta à crítica ao Estado, acusado de ser o responsável pela crise que assolava as nações.

No Brasil, seguindo tal orientação, a educação, antes vista como direito social a ser promovido pelo Estado, passou a ser entendida como serviço nãoexclusivo do mesmo, que não necessariamente deveria ser executado/prestado por ele, 
mas regulado, facilitado, promovido ou parcialmente financiado. O Estado deixou de ser executor (exclusivo) $)^{9}$ e passou a ser coordenador desse serviço. (COUTINHO, 2003).

O dever do Estado para com a educação está inscrito na Constituição Federal de 1988 - artigo $205^{10}$.

O artigo $208^{11}$ da Constituição Federal determina as formas de efetivação do dever do Estado.

Merece destaque a priorização do Ensino Fundamental obrigatório. Reserva-se a esse nível de ensino, a oferta púbica e gratuita. Esses aspectos revelam a assunção de uma política educacional baseada na focalização, visto que ao priorizar o ensino fundamental rompe-se com o princípio da universalização da educação em todos os níveis (DOURADO, 2001).

A despeito das limitações em termos de abrangência, a Carta Legal circunscreve a educação como direito de todos e dever do Estado, ao mesmo tempo em

\footnotetext{
${ }^{9}$ Embora o autor não use tal termo, entendemos que o Estado ainda opera como executor.

${ }^{10}$ Art. 205. A educação, direito de todos e dever do Estado e da família, será promovida e incentivada com a colaboração da sociedade, visando ao pleno desenvolvimento da pessoa, seu preparo para o exercício da cidadania e sua qualificação para o trabalho. (BRASIL, 1988)

${ }^{11}$ Art. 208. O dever do Estado com a educação será efetivado mediante a garantia de:

I - ensino fundamental, obrigatório e gratuito, assegurada, inclusive, sua oferta gratuita para todos os que a ele não tiveram acesso na idade própria;

II - progressiva universalização do ensino médio gratuito;

III - atendimento educacional especializado aos portadores de deficiência, preferencialmente na rede regular de ensino;

IV - educação infantil, em creche e pré-escola, às crianças até 5 (cinco) anos de idade;

$\mathrm{V}$ - acesso aos níveis mais elevados do ensino, da pesquisa e da criação artística, segundo a capacidade de cada um;

VI - oferta de ensino noturno regular, adequado às condições do educando;

VII - atendimento ao educando, no ensino fundamental, através de programas suplementares de material didático-escolar, transporte, alimentação e assistência à saúde.

$\S 1^{\circ}$ - O acesso ao ensino obrigatório e gratuito é direito público subjetivo.

$\S 2^{\circ}$ - O não-oferecimento do ensino obrigatório pelo Poder Público, ou sua oferta irregular, importa responsabilidade da autoridade competente.

$\S 3^{\circ}$ - Compete ao Poder Público recensear os educandos no ensino fundamental, fazer-lhes a chamada e zelar, junto aos pais ou responsáveis, pela freqüência à escola. (BRASIL, 1988)
} 
que determina seja pública e gratuita a educação (ainda que somente no ensino fundamental).

A Constituição Federal, ainda, reconhece o direito da iniciativa privada atuar na área educacional. Trata-se de uma concessão da oferta do serviço.

Art. 209. O ensino é livre à iniciativa privada, atendidas as seguintes condições:

I - cumprimento das normas gerais da educação nacional;

II - autorização e avaliação de qualidade pelo Poder Público. (BRASIL, 1988)

Temos, até o momento, duas idéias importantes a respeito da oferta dos serviços educacionais no Brasil: i) é dever do Estado, contudo relativizado pela lógica da focalização; ii) é livre à iniciativa privada, por meio da concessão governamental.

É nesse contexto de ampliação da atuação do mercado na área educacional em resposta ao reducionismo do Estado, que o Brasil atravessa as últimas décadas. Orientada pelos referenciais da reforma do Estado, que indicavam rumos para a privatização de parte da educação, a política educacional brasileira promoveu, principalmente no ensino superior, um verdadeiro desmonte.

O afrouxamento ou abrandamento dos critérios de autorização para criação de instituições de ensino superior, a transferência de recursos públicos (via renúncia fiscal ${ }^{12}$ ) para instituições de ensino privadas, o baixo investimento na universidade pública são apenas alguns exemplos da política educacional brasileira das últimas décadas que evidenciam seu caráter privatista.

Difunde-se a idéia de que "investir" na educação privada é menos oneroso e mais simples.

\footnotetext{
${ }^{12}$ PROUNI - Programa Universidade para Todos - Ver mais em Davies (2004)
} 
Davies (2004), ao analisar as políticas educacionais do início do governo Lula, denunciou as medidas neoliberais tomadas pelo governo. Para o autor, tratava-se de medidas de focalização dos gastos públicos e de redução da educação apenas ao seu aspecto econômico e economicista, transferindo-a para o setor privado.

Naquele momento, o Programa Universidade para Todos - PROUNIera ainda um projeto, contudo seus principais objetivos já eram difundidos. Pretendia-se ampliar o acesso ao ensino superior e para tanto as vagas ociosas das instituições privadas seriam trocadas por renúncia fiscal.

As vantagens anunciadas, visando justificar a necessidade de implantação do PROUNI, centravam-se na "lógica" de que as instituições privadas resolveriam seus problemas de vagas ociosas, seria mais barato para o governo investir nas instituições privadas do que nas públicas e, finalmente, a rapidez com que tais vagas seriam conseguidas, ao passo que nas públicas isso levaria muito tempo.

O autor faz sérias críticas ao discurso utilizado, principalmente em relação à preocupação com a ociosidade das instituições privadas e a com o custo menor das vagas em relação às das instituições públicas.

(...) é sempre bom lembrar que as públicas realizam atividades (pesquisa, atendimento médico em hospitais universitários, por exemplo) que, justamente por serem mais dispendiosas, não atraem o interesse da imensa maioria das privadas, que preferem se concentrar apenas no ensino, atividade mais econômica e industrializável. Portanto, se é verdade que o custo para criar uma vaga nas públicas é maior, é preciso ter em conta estes e muitos outros fatores, convenientemente não captados por um raciocínio puramente economicista e influenciado pela perspectiva neoliberal de contenção de gastos sociais. (DAVIES, 2004, p. 251)

As relações entre o público e o privado na educação, portanto, são marcadas por uma visão gerencial, coerente com a idéia de privatização dos serviços. Entretanto não é apenas pela via da privatização que as relações entre público e privado 
se estabelecem. Em situações específicas em que não é possível privatizar, a lógica de mercado orientará a ação Estatal, na perspectiva do quase-mercado.

O avanço do setor público não-estatal na oferta de serviços sociais no Brasil é impulsionado pela reforma do Estado. Nessa perspectiva, a saúde, a educação, a cultura e a pesquisa científica são considerados serviços não-exclusivos do Estado, os quais "o Estado provê, mas que, como não envolvem o exercício do poder extroverso do Estado, podem ser também oferecidos pelo setor privado e pelo setor público não-estatal ('não-governamental')" (BRESSER PEREIRA,1998, p. 34).

Legitima-se, dessa forma a transferência de serviços do setor estatal para o público não-estatal - estratégia identificada como publicização-, aprofundando o reducionismo na atuação do primeiro.

O público não-estatal, ou terceiro setor, refere-se ao setor da sociedade que, segundo Peroni e Adrião (2004), não se encontra no mercado, tampouco no Estado.

Entre os defensores da atuação do setor público não-estatal na oferta de políticas sociais temos os reformadores da Terceira Via.

O termo "Terceira Via" se refere

a uma estrutura de pensamento e de prática política que visa adaptar a social-democracia a um mundo que se transformou fundamentalmente ao longo das últimas duas ou três décadas. É uma terceira via no sentido de que é uma tentativa de transcender tanto a social democracia do velho estilo quanto o neoliberalismo. (GIDDENS, 2005, p. 36)

Os teóricos da Terceira Via argumentavam em favor de um projeto de reforma de Estado que visava transformar seu padrão de organização e gestão.

a reforma do estado e do governo deveria ser um princípio orientador básico da política da terceira via - um processo de aprofundamento e ampliação da democracia. O governo pode agir em parceria com instituições da sociedade civil para fomentar a renovação e o desenvolvimento a comunidade. (GIDDENS, 2005, p.79) 
A convergência entre as orientações políticas reformistas neoliberais e da Terceira Via residia no diagnóstico da crise, cuja responsabilidade era do Estado. Entretanto, as propostas para superação da crise eram diferentes. Enquanto o neoliberalismo defendia formas de privatização dos serviços estatais, a Terceira Via propunha sua transferência para o Terceiro Setor. Em ambas as propostas, o Estado deixava de ser responsável pela execução das políticas sociais (PERONI E ADRIÃO 2004).

Ainda que provisoriamente, podemos inferir que as articulações que se estabelecem entre o Público, o Privado e o Público não-Estatal em torno da oferta dos serviços educacionais tendem a reafirmar a omissão do Estado (aqui entendido como público), em detrimento de uma atuação mais efetiva dos demais setores.

Debates em torno da atuação do mercado na área educacional não são recentes, assim como não são recentes os "confrontos entre os defensores do ensino público e os defensores do ensino privado" (DOURADO e BUENO, 2001, p.91). Entretanto, as novas feições assumidas pelo mercado nas políticas educacionais carecem de uma análise mais ampla, principalmente se levarmos em conta os mecanismos de quase-mercado. Da mesma forma, a emergência do público não-estatal como executor de serviços educacionais merece um exame mais acurado. É o que buscaremos fazer na próxima seção. 


\subsection{A atuação das organizações públicas não-estatais na educação pública brasileira: nem Estado, nem mercado: quase-mercado}

Como vimos anteriormente, a presença do setor público não-estatal na educação pública foi legitimada no bojo da reforma do Estado brasileiro.

É importante destacar que em termos de atuação, não há previsão de transferência de oferta da educação obrigatória para o setor público não-estatal; entretanto os rearranjos da política educacional permitem (e incentivam) a celebração de parcerias que, ao fim e ao cabo, cumprem tal intento.

O setor público não-estatal, muitas vezes designado como Terceiro Setor, nasceu como alternativa a redução da presença do Estado nos setores sociais, resultantes da crise do Welfare State. Também nos Estados clientelistas e assistencialistas, que não viveram o Welfare State -, sentiu-se a ausência estatal. Assim o Terceiro Setor (ou público não-estatal) buscou prover ou reforçar a ação do Estado nas questões sociais (OLIVEIRA, 2005, p. 44).

As instituições que integram o Terceiro Setor fazem parte do espaço público não-estatal, caracterindo-se por instituições sem fins lucrativos, sendo elas as Organizações da Sociedade Civil (OSCs) e Organizações Não-Governamentais.

É chamado de Terceiro Setor porque engloba instituições com fins lucrativos, porém, de caráter privado, que não se enquadram, portanto, no Primeiro Setor (Estado) e são regidas pelo direito privado sem, contudo, possuir objetivos mercantis, não sendo qualificadas como instituições do Segundo Setor (Mercado) (OLIVEIRA, 2005, p.45)

Com base nos estudos de Voigt (1993), podemos considerar que o início da atuação do Terceiro Setor no Brasil é marcado pela presença das entidades 
religiosas nas atividades de cunho assistencialista na área social. Temos os exemplos das Santas Casas, orfanatos e asilos.

Nos anos de 1950 a hegemonia das entidades religiosas perde espaço frente a ampliação e diversificação de entidades sociais no país, cuja maioria originouse da expansão do sindicalismo brasileiro.

Durante a ditadura militar a expansão do Terceiro Setor se deu pela criação de associações comunitárias, movimento de moradores, clubes de mães, comunidades eclesiásticas que se encontravam separadas do Estado. (LUMERTZ, 2008).

Na década de 1980, no bojo do movimento de rearticulação partidária, as organizações do Terceiro Setor foram impulsionadas a expandir sua participação nos setores sociais.

O arcabouço legal ${ }^{13}$ da década de 1990 deu sustentação ao projeto estatal de transferência “da responsabilidade da execução e controle das políticas sociais públicas do Estado para a sociedade civil organizada ou ainda diretamente para a esfera privada" (LUMERTZ, 2008, p.36). Em 2004 foi editada a Lei n 11.079 que tratou das parcerias Público-Privadas, revelando o caráter de continuidade e aprofundamento dessas políticas.

Segundo dados do IBGE $^{14}$ - Instituto Brasileiro de Geografia Estatística - (2005), atuam no Brasil cerca de 338 mil entidades do Terceiro Setor. Desse contingente, $8,1 \%$, ou 27 mil entidades, possuem a finalidade de desenvolver

\footnotetext{
${ }^{13}$ Lei $^{\circ}$ 9.637/98, Lei $n^{\circ}$ 9.770/99, Decreto $n^{\circ} 3.100 / 99$.

14 A pesquisa se deu por meio de uma parceria com o Instituto de Pesquisa Econômica Aplicada - IPEA, a Associação Brasileira de Organizações Não Governamentais - ABONG e o Grupo de Institutos, Fundações e Empresas - GIFE com o objetivo de mapear o universo das organizações da sociedade civil que atendem, simultaneamente, aos critérios de entidades privadas, sem fins lucrativos, institucionalizadas, auto-administradas e voluntárias.
} 
ações de Educação e pesquisa, Saúde, Meio Ambiente e proteção animal e Habitação. Em Educação e pesquisa são 19,9 mil organizações, sendo que quase a metade está na Região Sudeste.

A atuação das organizações do Terceiro Setor na oferta dos serviços sociais é regulada pela Lei $n^{0}$ 9637/98 e pela Lei ${ }^{\circ}$ 9790/99. Tal oferta se dá por meio de parcerias com o setor público ou pela assunção direta, a depender do tipo e natureza da instituição.

Muitos são os exemplos de atuação do Terceiro Setor na Educação Infantil. Esse nível de ensino, notadamente preterido nas políticas educacionais do governo brasileiro, enfrentou nos últimos anos substancial diminuição de aporte financeiro, em decorrência da explícita priorização do ensino fundamental, materializada na consagração desse nível de ensino como obrigatório e público, cuja responsabilidade de oferta estaria a cargo dos municípios e do Estado. Acrescente-se a esse quadro a criação do FUNDEF - Fundo de Manutenção e Desenvolvimento do Ensino Fundamental e de Valorização do Magistério - mecanismo indutor dos processos de municipalização do ensino fundamental.

Tais elementos contribuíram para a focalização de políticas e recursos no ensino obrigatório, relegando a Educação Infantil um papel diminuto e secundário. A falta de vagas nesse nível de ensino evidenciam tal quadro.

A ineficiência do Estado na tarefa de prover a Educação Infantil de forma universal, aliada a impossibilidade do setor privado absorver toda a demanda, dadas as restrições financeiras dessa população, contribuíram para a efetivação do Terceiro Setor como alternativa viável de atendimento. 
São muitos os casos de celebração de convênio entre municípios e organizações do Terceiro Setor na educação infantil. Na cidade de Porto Alegre, por exemplo, contabilizaram-se ${ }^{15}$, em 2008, 5.619 matrículas na Educação Infantil em instituições públicas, contra 9.231 em creches comunitárias ou conveniadas. É importante considerar que os convênios implicam contrapartida financeira dos municípios, entretanto, ainda são mais vantajosos e baratos que a oferta direta, que implicaria na construção de escolas, formação de equipes escolares. Cabe analisar, por fim, se as vantagens econômicas estão acompanhadas de uma oferta qualificada.

As estratégias da denominada publicização da educação atingem outros níveis, modalidades e serviços, tais como a Educação de Jovens e Adultos (EJA), formação de professores, gestão educacional, aquisição de material escolar, entre tantas outras.

A oferta da Educação de Jovens e Adultos pelo Terceiro Setor guarda grande similaridade com o que ocorre na Educação Infantil, principalmente no que tange à minimização da presença do Estado. A opção pela priorização do ensino fundamental regular (faixa de 7 a 14 anos,) determinada pelas restrições financeiras impostas pelo FUNDEF ${ }^{16}$, colaborou para que a Educação de Jovens e Adultos fosse, nas últimas décadas, "abandonada" no cenário das políticas educacionais. "O vácuo deixado pela ausência de políticas públicas nacionais de escolarização de jovens e adultos tendeu a ser ocupado por iniciativas locais, em geral concretizadas por meio de parcerias entre governos municipais e organizações da sociedade civil” (DI PIERRO e GRACIANO, 2003, p. 17)

\footnotetext{
${ }^{15}$ Dados da Secretaria Municipal de Educação de Porto Alegre.

${ }^{16}$ Segundo critérios do FUNDEF, os alunos matriculados na Educação de Jovens e Adultos não eram considerados no cômputo das matrículas do Ensino Fundamental.
} 
Ações de formação de professores, assessoria pedagógica para elaboração de projetos educacionais, planos de educação, gestão da escola e de sistemas educativos também tem sido objeto das organizações do Terceiro Setor. O que demarca esse contexto são as relações estabelecidas entre os setores Público e Público nãoEstatal, entretanto, a presença do mercado permeia essas relações.

Ao delegar atividades ao setor Púbico não-Estatal, o Estado se desresponsabiliza de algumas de suas funções, mas mantém a tutela sobre as escolas e sistemas educativos. Trata-se de uma reengenharia entre oferta, financiamento e regulação dos serviços educacionais, pautada na dinâmica de quase-mercado. O quasemercado educacional no contexto de publicização dos serviços sociais explicita a imbricação das relações entre os setores, cuja divisa tem se tornado cada vez mais tênue.

As organizações do Terceiro Setor que atuam na educação pública têm adotado a utilização de mecanismos de mercado nessa tarefa, por meio, por exemplo, da introdução de um modelo de administração gerencial, focado nos resultados. É o caso do Programa Gestão para o Sucesso Escolar idealizado pelo Instituto Protagonistés ${ }^{17}$ e realizado e patrocinado pela Fundação Lemann ${ }^{18}$ e os Programas desenvolvidos pelo Instituto Airton Senna.

O Programa Gestão para o Sucesso Escolar consistia na capacitação de gestores com o objetivo de fortalecer o papel de liderança pedagógica necessário à melhoria da qualidade da educação.

O site do programa traz informações sobre seus objetivos e metodologia. Destaca-se que o conteúdo do programa era baseado na lógica da prática

\footnotetext{
${ }^{17}$ O Instituto tem como presidente a ex-secretária de Educação de São Paulo Teresa Roserley Neubauer da Silva.

${ }^{18}$ O ex-ministro da Educação (gestão Fernando Henrique Cardoso) Paulo Renato Souza é membro da diretoria da Fundação.
} 
gerencial por resultados e previa monitoramento, por meio de avaliações externas no início e final do desenvolvimento do projeto que objetivavam medir a evolução dos alunos.

É importante destacar que as escolas que obtiveram melhores resultados nas avaliações realizadas foram premiadas, assim como seus diretores.

A atuação do Instituto Airton Senna foi objeto de estudo de Lumertz (2008). Focando a análise sobre a parceria firmada entre o Instituto e um município do Rio Grande do Sul, a autora denuncia a institucionalização das práticas gerenciais no cotidiano escolar.

O objetivo do programa desenvolvido era a promoção da melhoria da aprendizagem e do gerenciamento dos sistemas educacionais. Havia a previsão de acompanhamento de resultados pautado na análise de indicadores de promoção, retenção, freqüência de alunos e alcance de metas ligadas à gestão.

Diante do exposto até o momento, podemos inferir que o intento reformista teve na área educacional grande sucesso. Mais do que pôr em prática as prescrições do programa de reforma, a articulação dos setores público, privado e público não-estatal, promoveu uma combinação "explosiva” dessas prescrições.

No capítulo a seguir apresentaremos, por meio da análise documental, evidências da presença de mecanismos de quase-mercado nas políticas educacionais implementadas à partir da década de 1980, com foco na análise da gestão educacional, avaliação e formação de professores. 


\section{CAPÍTULO 3}

A GESTÃO EDUCACIONAL NA PERSPECTIVA DO QUASE-MERCADO: o que dizem os documentos oficiais 
A organização do presente capítulo tem por objetivo analisar o conceito de gestão presente nos documentos oficiais produzidos nas últimas duas décadas, buscando, a princípio, evidenciar a congruência de sentido entre as concepções presentes no discurso oficial e aquelas que sustentam as propostas de reforma educacional.

Buscaremos destacar, além das similaridades de sentido, o compromisso assumido pelos governos brasileiros na implantação do novo paradigma de gestão, cujas ações visaram a ampliação da eficiência do Estado, por meio da implantação de uma lógica mercantil no seio da gestão da escola pública.

Pretende-se analisar a evolução do conceito de gestão e seu emprego nos documentos que traçam as diretrizes das políticas educacionais. Parece-nos claro que a intencionalidade presente no uso do termo, em substituição a administração, ancora-se na tentativa de transplantação do "espírito" presente na organização privada, principalmente da lógica produtivista.

Evidentemente, práticas correspondem a valores de suporte. A importação para ambientes de administração pública de práticas da administração privada viabiliza a circulação no espaço público dos critérios, valores e interesses a que essas práticas se reportam. Com isso diluem-se as fronteiras entre o sentido do público e o sentido do privado, em favor deste e em detrimento daquele (SILVA JÚNIOR, 2002, p. 202).

Analisaremos dois documentos que entendemos essenciais no movimento de construção da recente política educacional brasileira e que podem clarificar as concepções e os objetivos propostos para a gestão da educação:

- Plano Nacional de Educação (PNE);

- Plano de Desenvolvimento da Educação (PDE). 
Para dar sustentação à análise dos documentos, propormos a discussão das concepções de gestão presentes na Constituição Federal e na Lei no 9394/96 - Lei de Diretrizes e Bases da Educação Nacional - LDB.

Entretanto, partiremos da análise do conceito de gestão (e seu significado) visando compreender qual noção lhe é atribuída no quadro atual da política educacional.

\subsection{A Gestão nas recentes políticas educacionais brasileiras: breve estudo do conceito e de seu significado}

Na realização deste trabalho elegemos as categorias que serviriam para guiar a pesquisa acerca das manifestações e evidências da presença de mecanismos de quase-mercado na educação pública.

A gestão foi eleita como uma importante categoria, visto que, num contexto de mercantilização da educação, a implantação das ferramentas próprias do mercado se dá, primeiramente, pela gestão. Ou ainda, é pela via da gestão - que envolve o planejamento, a organização, o controle - que são conduzidas e implantadas as mudanças.

Assim, entendemos oportuna uma análise, ainda que breve, acerca do uso do termo e seu significado nesse contexto.

Entendemos que a opção (governamental) pelo uso do termo gestão em substituição à administração já revela certa compatibilidade e congruência com os objetivos da política educacional vigente. 
Para Russo (2004) os estudos e pesquisas realizados por autores como Felix (1984), Paro (1986, 1991) e Russo (1991) revelaram que no Brasil a administração educacional pautava-se, teórica e praticamente, no paradigma da administração empresarial que encontrava na Teoria Geral da Administração (TGA) a expressão de seu pensamento e a formulação de suas práticas.

Para o autor, até meados da década de 1980 os autores de livros, ensaios e teses sobre Administração Escolar utilizavam o arcabouço teórico dos movimentos que compunham a teoria da administração empresarial como fundamento para suas propostas. Entendiam tais autores, conforme assinala Russo, que administrar uma escola equivaleria a administrar uma empresa.

Cabe destacar, contudo, que um novo movimento se deu, ainda na década de 1980, a partir do entendimento de que os fundamentos da Teoria Geral da Administração eram incompatíveis com as especificidades da escola e, portanto, era preciso construir uma teoria de Administração Escolar que desse conta de tais especificidades.

(...) a busca de uma especificidade para a Administração Escolar coincide com a busca de uma nova Administração Escolar, que se fundamente em objetivos educacionais representativos dos interesses das amplas camadas dominadas da população e que leve em conta a especificidade do processo pedagógico escolar, processo este determinado por esses mesmos objetivos (PARO, 1987, p. 152).

O que se buscava superar era a idéia de uma administração escolar ancorada em princípios de administração próprios das empresas capitalistas.

Mais recentemente alguns autores se dedicaram a discutir a introdução do termo gestão em substituição a administração para designar os processos ocorridos na educação. Silva Jr (2001) evidenciou o predomínio da noção de gestão sobre a de administração afirmando que desse predomínio decorria a "indução do significado de 
gestão como gestão empresarial, ou, seja o embotamento da produção do significado de gestão educacional”. (SILVA JR., 2002, p.199).

E prosseguiu o autor, "identificando gestão como gestão empresarial, observa-se a crescente mercadorização dos critérios de gestão educacional, com a prevalência da lógica do mercado educacional sobre a lógica do direito à educação. (SILVA JR, 2002).

Nesse contexto particular, a gestão colabora para a relativização da noção de educação enquanto direito social, atribuindo a ela um caráter de mercadoria. Mais do que o uso do termo, trata-se da intencionalidade do uso, visto que o que está em jogo é a noção atribuída à gestão.

A busca pela legitimidade desse tipo de política também merece destaque, visto que é pela via da retórica que ela se configura. Assim, a transplantação das formas de gestão empresarial para a escola pública se dá ancorada em um discurso cuidadosamente construído que põe em evidência as qualidades do modelo adotado, escamoteando intenções. "O que temos hoje, no país, é uma política educacional que visa subordinar integralmente a educação aos interesses ideológicos e econômicos do capital, ainda que contraditoriamente ao discurso oficial do governo" (RUSSO, 2004, p.38)

Parece-nos razoável considerar que a noção de gestão que se pretende implantar tem o mercado como referência, principalmente em termos de eficiência e eficácia no alcance dos resultados.

Veremos na seção seguinte uma análise sobre a concepção de gestão presente na Constituição Federal de 1988 e na Lei de Diretrizes e Bases da Educação Nacional. 


\title{
3.2 A Gestão Educacional na Constituição Federal de 1988 e na Lei de Diretrizes e Bases da Educação Nacional: evidências da presença do quase-mercado.
}

Tendo a educação básica como foco das análises do presente estudo, investigaremos no texto da Carta Constitucional referências à gestão educacional voltada à tal etapa.

Importa antes sublinhar que a Constituição Federal de 1988 não impôs um novo modelo de gestão pública de características mercantis ou de cariz privado. Tanto é verdade que a Carta Constitucional foi tida como retrógrada em relação a esse aspecto, conforme evidenciou Bresser Pereira (1999).

\begin{abstract}
a Constituição irá sacramentar os princípios de uma administração pública arcaica, burocrática ao extremo. Uma administração pública altamente centralizada, hierárquica e rígida, em que toda a prioridade será dada à administração direta ao invés da indireta. A Constituição de 1988 ignorou completamente as novas orientações da administração pública (p.8)

(...)

Na medida que a Constituição de 1988 representou um retrocesso burocrático, revelou-se irrealista. Em um momento em que o país necessitava urgentemente reformar a sua administração pública, de forma a torná-la mais eficiente e de melhor qualidade, aproximando-a do mercado privado de trabalho, o inverso foi realizado. (p.13)
\end{abstract}

De fato, foram as ações pró-reforma do Estado que promoveram a introdução de um novo modelo de gestão pública, cujo alcance, obviamente, abarcou a educação.

Todavia, parece-nos importante destacar o texto do artigo $206 \mathrm{da}$ Constituição Federal que trata dos princípios do ensino. Nele, mais especificamente em seu inciso VI ${ }^{19}$, a gestão democrática do ensino público apareceu como princípio a ser

\footnotetext{
${ }^{19}$ Art. 206. O ensino será ministrado com base nos seguintes princípios:

(...)

VI - gestão democrática do ensino público, na forma da lei; (BRASIL, 1988)
} 
aplicado. Nessa perspectiva, propôs-se uma forma de gestão cujo significado e sentido, dadas as simplificações e sintetizações do texto legal, não foram explicitados.

Entendemos tratar-se de vazios da lei, omissões normativas que, se por um lado atendem a anseios populares históricos, por outro, delegam a outra norma (no caso a Lei de Diretrizes e Bases da Educação Nacional) ou outro ente a tarefa de definir sobre as formas de "organização e institucionalização de mecanismos de implementação da gestão democrática nas instituições públicas de educação" (RIBEIRO, [s.d], p.7).

O mesmo princípio (gestão democrática do ensino público), conforme já indicado, reaparece no texto da Lei no 9394/96 (Lei de Diretrizes e Bases da Educação Nacional - LDB), no inciso VIII do artigo $3^{\circ}$, com a seguinte redação:

Art. $3^{\circ} \mathrm{O}$ ensino será ministrado com base nos seguintes princípios: (...) VIII - gestão democrática do ensino público, na forma desta Lei e da legislação dos sistemas de ensino. (BRASIL, 1996)

Seguindo a mesma linha de vazios e omissões da Carta Constitucional, a LDB também não definiu o significado da gestão que se pretendia imprimir e delegou aos sistemas de ensino tal tarefa.

Tais vazios ou omissões resultam conseqüências, conforme já apontado por diversos autores, como Lima (1992), Machado (2005) e Vasconcelos (1998).

Ainda na LDB de 1996, a gestão democrática foi retomada no artigo 14, reforçando a idéia de que caberia aos sistemas de ensino definirem as normas dessa forma de gestão, cujo alcance se limitava ao ensino público na educação básica. As 
peculiaridades locais deveriam ser consideradas nessa tarefa de definição de normas de gestão, e os seguintes princípios considerados:

I - participação dos profissionais da educação na elaboração do projeto pedagógico da escola;

II - participação das comunidades escolar e local em conselhos escolares ou equivalentes. (BRASIL, 1996).

Os princípios apontados na Lei são, de fato, importantes se considerarmos que não poderá haver gestão democrática sem participação.

Conforme destacou Oliveira (2002), “a gestão democrática da educação, imperativo constitucional, reflete o desejo de uma sociedade que repudia o autoritarismo, contemplando os anseios profissionais da educação e dos usuários de serviços educacionais” (p. 80).

Podemos considerar que em termos práticos a aplicação dos princípios da gestão democrática se deu, em grande medida, pela criação de órgãos colegiados compostos por representantes dos diferentes segmentos ligados à educação.

No estudo de Oliveira (2002) sobre gestão da educação nos anos de 1990, o autor indicou que o MEC, naquele período, tomava medidas voltadas à formação de colegiados - "base de uma gestão democrática" (p.80); contudo o fazia preocupado com a eficiência e eficácia do sistema.

Cabe lembrar que a promulgação da LDB ocorreu durante o período de maior efervescência reformista. Nesse contexto, cuja inspiração neoliberal é inegável, muitos conceitos e princípios foram ressignificados em nome de um novo modelo de Estado, menos burocrático e mais flexível e eficiente, enfim, mais próximo do modelo do mercado. 
Os princípios de gestão democrática e participação foram apropriados pela onda reformista e transformados em pilares da responsabilização da sociedade e da escola pelos destinos da educação.

Conforme aponta Rossi (2001)

Nas últimas décadas, outros grupos de interesses, aproveitaram-se desse argumento democrático de longa duração entre grupos progressistas, transformando-o em um dos pilares mais conservadores da racionalidade técnica e instrumental. A fim de orientar-se e dividir responsabilidades políticas, reclamam um novo tratamento as relações entre poderes atribuídos aos que participam da educação no tempo flexível ditado pelo mercado. Quais os outros grupos interessados em fazer com que na democracia escolar os agentes sociais tomem em suas próprias mãos seu próprio destino? (p. 92)

Perece-nos claro que se tratava de uma estratégia de

desresponsabilização do Estado, mascarada por um discurso que prometia e clamava por uma maior participação da sociedade na condução das questões da educação. O que se efetivou, contudo, foi uma nova forma de gerir na perspectiva da eficiência e eficácia, típicas do modelo mercantil, cuja característica marcante é a assunção dos problemas e das suas resoluções (por parte da sociedade).

(...) seguindo referenciais de inspiração neoliberal no quadro da reforma administrativa do Estado, a má gestão foi tomada como, praticamente, a causa de todos os males que afetam os processos de ensino e aprendizagem. Visando superá-los, realizou-se um tipo de interpretação da realidade que conduziu às tentativas de adoção da gestão gerencial nas escolas e, através de processos de desconcentração/municipalização, privilegiamento do local, dentre outras medidas, tentou-se delegar às unidades escolares, aos professores e à comunidade a solução dos problemas que vêm contribuindo para que não tenhamos uma educação pública de qualidade (AZEVEDO, 2005).

Não é possível afirmar que a Constituição Federal e a LDB trouxeram nos princípios que norteiam o ensino público a explicitação da introdução de 
mecanismos de quase-mercado na gestão educacional. Entretanto, cabe considerar que o contexto reformista vigente, em especial durante a tramitação e aprovação da LDB, determinou a manifestação da introdução de tais mecanismos na gestão da escola pública.

As mazelas da gestão pública foram reiteradamente expostas, por meio da divulgação de seus parcos resultados, de sua alta burocracia, de seu custo elevado. Nessa linha, buscou-se imprimir uma gestão capaz de superar a ineficiência do Estado, por meio da introdução da lógica da gestão mercantil na educação pública. O conceito de gestão democrática foi, em muitos casos, apropriado e serviu a tal objetivo, na medida em que assumiu como legítimos os problemas do modelo de gestão vigente e buscou imprimir uma administração centrada na superação das falhas e na busca de maior eficiência, onde a participação social seria fundamental.

A Constituição Federal e a LDB trazem os princípios gerais que norteiam as políticas educacionais vigentes. Dessa forma, emprestam suas concepções e posicionamentos e, ao mesmo tempo, têm revisitados e ressignificados muitos de seus conceitos defendidos, num movimento de apropriação e legitimação que visa dar concretude e solidez ao projeto de educação que se pretende implantar pela via da política pública.

Nas seções subseqüentes analisaremos o Plano Nacional de Educação e o Plano de Desenvolvimento da Educação, respectivamente, buscando identificar as concepções de gestão educacional que tais documentos defendem e as possíveis evidências da presença de mecanismos de quase-mercado determinando tais concepções. 


\subsection{A Gestão Educacional no Plano Nacional de Educação}

A Constituição Federal de 1988 previu a existência do Plano Nacional de Educação. De duração plurianual, o Plano visava à articulação e ao desenvolvimento do ensino nos diferentes níveis e à integração das ações do Poder Público ${ }^{20}$ com vistas à erradicação do analfabetismo, universalização do atendimento escolar, melhoria da qualidade do ensino, formação para o trabalho e promoção humanística, científica e tecnológica do país.

No percurso de criação do plano foram apresentadas duas propostas: uma proposta da sociedade - resultante de dois Congressos Nacionais de Educação CONED - e outra proposta elaborada pelo MEC.

Oliveira (2002) ao comparar as duas propostas, indicou que a proposta elaborada pelo CONED apresentava mais preocupação com a gestão democrática e com os meios para garantir sua consolidação, enquanto a proposta do MEC revelava preocupação com a eficiência e eficácia do sistema. Assim, segundo o autor,

A gestão democrática para os primeiros se realiza por intermédio de colegiados prioritariamente constituídos; já para o MEC, esta gestão democrática pressupõe o preparo de recursos humanos para informatização, administração e avaliação das escolas (OLIVEIRA, 2002, p. 80)

A proposta da sociedade (CONED) foi a primeira a ser apresentada e teve como primeiro signatário o deputado Ivan Valente. O governo propôs um

\footnotetext{
${ }^{20}$ O artigo 214 da Constituição federal de 1988 que tratou do Plano Nacional de Educação teve sua redação alteada pela Emenda Constitucional n ${ }^{\circ} 59$ de 11 de novembro de 2009, passando o Caput do artigo a vigorar da seguinte forma:

“Art. 214. A lei estabelecerá o plano nacional de educação, de duração decenal, com o objetivo de articular o sistema nacional de educação em regime de colaboração e definir diretrizes, objetivos, metas e estratégias de implementação para assegurar a manutenção e desenvolvimento do ensino em seus diversos níveis, etapas e modalidades por meio de ações integradas dos poderes públicos das diferentes esferas federativas que conduzam a:"

Para os fins desse trabalho, e considerando que o Plano Nacional de Educação em vigência teve como referência o artigo inalterado, tomaremos sua redação inicial.
} 
substitutivo, cujo conteúdo contemplava as idéias da proposta do MEC, contudo incorporando algumas questões postas pelo CONED.

No que se refere à gestão educacional, o Plano Nacional de Educação - PNE -, retomou a idéia da gestão democrática, em consonância com o que dispôs a Constituição Federal de 1988 e a Lei de Diretrizes e Bases da Educação. Enquanto os dois últimos tinham a gestão democrática como princípio a ser atendido no ensino público, o Plano Nacional de Educação trouxe tal conceito como um dos cinco objetivos a serem atingidos.

\footnotetext{
Em síntese, o Plano tem como objetivos:

. a elevação global do nível de escolaridade da população;

. a melhoria da qualidade do ensino em todos os níveis;

. a redução das desigualdades sociais e regionais no tocante ao acesso e à permanência, com sucesso, na educação pública $\mathrm{e}$

. democratização da gestão do ensino público, nos estabelecimentos oficiais, obedecendo aos princípios da participação dos profissionais da educação na elaboração do projeto pedagógico da escola e a participação das comunidades escolar e local em conselhos escolares ou eqüivalentes. (g.n.) (BRASIL, 2001)
}

Ao mesmo tempo em que o PNE elegeu objetivos (dentre eles a democratização da gestão do ensino público), que demandariam estratégias para seu cumprimento, sublinhou as dificuldades e limitações - inclusive financeiras - do país em alcançar uma educação compatível com a oferecida nas nações desenvolvidas, assim estabeleceu prioridades $^{21}$, "segundo o dever constitucional e as necessidades sociais" (BRASIL, 2001).

21 1. Garantia de ensino fundamental obrigatório de oito anos a todas as crianças de 7 a 14 anos, assegurando o seu ingresso e permanência na escola e a conclusão desse ensino. Essa prioridade inclui o necessário esforço dos sistemas de ensino para que todas obtenham a formação mínima para o exercício da cidadania e para o usufruto do patrimônio cultural da sociedade moderna. O processo pedagógico deverá ser adequado às necessidades dos alunos e corresponder a um ensino socialmente significativo. Prioridade de tempo integral para as crianças das camadas sociais mais necessitadas.

2. Garantia de ensino fundamental a todos os que a ele não tiveram acesso na idade própria ou que não o concluíram. A erradicação do analfabetismo faz parte dessa prioridade, considerando-se a alfabetização de jovens e adultos como ponto de partida e parte intrínseca desse nível de ensino. A alfabetização dessa 
Cabe destacar que a estratégia da priorização presente no PNE

representa, conforme indica PINTO (2002), coerência com o pensamento neoliberal e, portanto, explicita um compromisso de focalização de políticas e racionalização de recursos, bem aos moldes do que se pratica no mercado.

Quanto à gestão, ao estabelecer como meta o desenvolvimento de sistemas de informação e de avaliação, além da coleta e difusão de dados como instrumentos de gestão e melhoria do ensino (prioridade 5), o PNE assumiu duas posturas importantes: i) a ênfase na avaliação como importante instrumento de controle, indispensável para a gestão, e ii) a avaliação e a regulação como instrumentos indutores de qualidade.

Para Oliveira e Silva (2007), as discussões que permeiam a problemática da regulação trazem a avaliação dos sistemas educacionais como um mecanismo e instrumento de controle. "Justificada no discurso da transparência,

população é entendida no sentido amplo de domínio dos instrumentos básicos da cultura letrada, das operações matemáticas elementares, da evolução histórica da sociedade humana, da diversidade do espaço físico e político mundial e da constituição da sociedade brasileira. Envolve, ainda, a formação do cidadão responsável e consciente de seus direitos e deveres.

3. Ampliação do atendimento nos demais níveis de ensino - a educação infantil, o ensino médio e a educação superior. Está prevista a extensão da escolaridade obrigatória para crianças de seis anos de idade, quer na educação infantil, quer no ensino fundamental, e a gradual extensão do acesso ao ensino médio para todos os jovens que completam o nível anterior, como também para os jovens e adultos que não cursaram os níveis de ensino nas idades próprias. Para as demais séries e para os outros níveis, são definidas metas de ampliação dos percentuais de atendimento da respectiva faixa etária. A ampliação do atendimento, neste plano, significa maior acesso, ou seja, garantia crescente de vagas e, simultaneamente, oportunidade de formação que corresponda às necessidades das diferentes faixas etárias, assim como, nos níveis mais elevados, às necessidades da sociedade, no que se refere a lideranças científicas e tecnológicas, artísticas e culturais, políticas e intelectuais, empresariais e sindicais, além das demandas do mercado de trabalho. Faz parte dessa prioridade a garantia de oportunidades de educação profissional complementar à educação básica, que conduza ao permanente desenvolvimento de aptidões para a vida produtiva, integrada às diferentes formas de educação, ao trabalho, à ciência e à tecnologia.

4. Valorização dos profissionais da educação. Particular atenção deverá ser dada à formação inicial e continuada, em especial dos professores. Faz parte dessa valorização a garantia das condições adequadas de trabalho, entre elas o tempo para estudo e preparação das aulas, salário digno, com piso salarial e carreira de magistério.

5. Desenvolvimento de sistemas de informação e de avaliação em todos os niveis e modalidades de ensino, inclusive educação profissional, contemplando também o aperfeiçoamento dos processos de coleta e difusão dos dados, como instrumentos indispensáveis para a gestão do sistema educacional e melhoria do ensino. 
prestação de contas e demonstração de resultados, aparece como indispensável na nova configuração da regulação das políticas públicas” (p.12).

Para as autoras, a avaliação é apresentada nos discursos políticos oficiais vinculada à qualidade do ensino público.

Tamanha ênfase explica-se pela capacidade atribuída à avaliação de melhorar a qualidade do ensino ao propiciar a visibilidade da realidade educacional através dos resultados, fornecendo elementos para a superação dos problemas detectados. (OLIVEIRA E SILVA, 2007, p.12)

Considerando os objetivos e prioridades do PNE em relação à gestão da educação, tudo indica que ao buscar alcançar a democratização da gestão do ensino público, garantindo a participação da comunidade escolar e local na elaboração da proposta pedagógica e nas instâncias decisórias, respectivamente, somada à questão da priorização da avaliação como elemento indispensável à gestão e ao alcance da melhoria da qualidade da educação, propôs-se uma espécie de transferência de determinadas funções de competência estatal para os órgãos locais, além de ampliar a regulação e o controle, que passaram a ser vistos como elementos indispensáveis para o alcance da qualidade.

A gestão educacional foi citada no Plano Nacional de Educação nos diferentes níveis e modalidades de ensino, bem como na seção que tratou do Financiamento e da Gestão.

Na educação infantil, a gestão foi tratada nos objetivos e metas nos itens 16 e 19.

16. Implantar conselhos escolares e outras formas de participação da comunidade escolar e local na melhoria do funcionamento das instituições de educação infantil e no enriquecimento das oportunidades educativas e dos recursos pedagógicos.

19. Estabelecer parâmetros de qualidade dos serviços de educação infantil, como referência para a supervisão, o controle e a avaliação, e 
como instrumento para a adoção das medidas de melhoria da qualidade. (BRASIL, 2001)

Evidencia-se, nos itens analisados, a tentativa de responsabilização da comunidade escolar e local pela melhoria de condições de funcionamento, oferta e qualidade da educação infantil, além da ênfase nos processos de monitoramento e regulação como condição para alcance de qualidade.

Tais premissas estão presentes ao longo de todo o texto do PNE e ressurgem, com maior ou menor força, nos demais níveis e modalidades. Todavia, é no ensino fundamental que as idéias e elementos de viés mercadológico se manifestam mais explicitamente.

Nas diretrizes para o ensino fundamental, a gestão da educação e a cobrança de resultados são definidas como tarefas da comunidade escolar e local. São contemplados a consolidação e aperfeiçoamento do Sistema Nacional de Avaliação da Educação Básica (SAEB), bem como a criação de sistemas complementares nos Estados e Municípios, sendo que ambos permitiriam "um permanente acompanhamento da situação escolar do País, podendo dimensionar as necessidades e perspectivas do ensino médio e superior" (BRASIL, 2001).

Nos objetivos e metas para o Ensino Fundamental a gestão é assim tratada:

9. Promover a participação da comunidade na gestão das escolas, universalizando, em dois anos, a instituição de conselhos escolares ou órgãos equivalentes.

24. Articular as atuais funções de supervisão e inspeção no sistema de avaliação.

26. Assegurar a elevação progressiva do nível de desempenho dos alunos mediante a implantação, em todos os sistemas de ensino, de um programa de monitoramento que utilize os indicadores do Sistema Nacional de Avaliação da Educação Básica e dos sistemas de avaliação dos Estados e Municípios que venham a ser desenvolvidos (BRASIL, 2001). 
Retoma-se a questão da participação da comunidade na gestão, a avaliação como instrumento de regulação e elevação de qualidade. A recorrência de tais pontos parece-nos não ser desinteressada. É possível identificar no discurso utilizado elementos que traduzem um modelo de gestão gerencial, pautado no controle e no acompanhamento de resultados, que promete solucionar os problemas contando com a participação de uma comunidade ativa e competente.

Nas diretrizes para o ensino médio, o texto do PNE indica que as metas de expansão da oferta e melhoria da qualidade desse nível de ensino deveriam estar associadas a estratégias de correção de fluxo dos alunos na escola básica. Indica, ainda, a necessidade do estabelecimento de um sistema de avaliação para o acompanhamento dos resultados desse nível de ensino, além da correção de seus equívocos. Defende-se a tese de que os sistemas de avaliação existentes e praticados constituem mecanismos de promoção de eficiência e igualdade do ensino médio oferecido no país.

Embora o conceito nuclear de avaliação como promotor de qualidade seja retomado, duas novas idéias, de inspiração mercadológica, surgem: a primeira diz respeito à questão da eficiência, que pode ser entendida numa lógica produtivista como alcance ótimo dos objetivos. Parece-nos razoável tal interpretação, uma vez que a questão da distorção idade x série introduz a necessidade da criação de sistemas de avaliação e monitoramento.

A segunda idéia refere-se à promoção da igualdade do ensino médio oferecido nas diferentes regiões do país pela via da avaliação, como se ela, por si só, 
fosse capaz de universalizar uma educação de qualidade. Abre-se aqui, ao que nos parece, o estatuto da comparação.

Ainda na seção que trata do Ensino Médio, nos objetivos e metas, o

PNE estabelece:

3. Melhorar o aproveitamento dos alunos do ensino médio, de forma a atingir níveis satisfatórios de desempenho definidos e avaliados pelo Sistema Nacional de Avaliação da Educação Básica (SAEB), pelo Exame Nacional do Ensino Médio (ENEM) e pelos sistemas de avaliação que venham a ser implantados nos Estados (BRASIL, 2001)

As evidências de mecanismos de quase-mercado ficam, a cada seção analisada, mais claras. Da análise desse objetivo podemos inferir que a "cultura do desempenho" (Santos, 2004) se manifesta de maneira definitiva, indicando, assim, os propósitos mais amplos do Estado avaliador.

De certa forma, pode-se dizer que, valendo-se de argumentos que atraem o interesse público pelos seus apelos democráticos, esse tipo de Estado exerce sua função com a adesão de grandes setores da população. A emergência e o desenvolvimento do Estado avaliador são justificados e legitimados como uma importante maneira de tornar transparente para o público a forma como as instituições atuam e utilizam os recursos públicos (SANTOS, 2004, p.1151-1152).

Nessa perspectiva, cabe ao poder central estabelecer os indicadores de desempenho que, no limite, definem o que é passível de ser mensurado, centralizando, dessa forma, o currículo e passando a idéia de um Estado interessado e comprometido com a educação. Por outro lado, conforme indica a autora, aquilo que não é passível de mensuração perde a importância e deixa de ser contemplado. Como conseqüências temos o engessamento do currículo, a busca por resultados, a competição, o controle social, numa clara expressão de educação como mercadoria que exige uma gestão racional que vise justificar os investimentos e cujos resultados expressem eficiência, eficácia e produtividade. 
Constitui, ainda, objetivo do ensino médio a participação da comunidade na gestão, manutenção e melhoria das condições de funcionamento da escola (objetivo 13), bem como a autonomia das escolas no tratamento das questões de caráter pedagógico e administrativo, aqui entendidas aquelas relativas à gerência dos recursos para manutenção do cotidiano escolar (objetivo 14).

Peroni e Adrião (2004, s.p.), destacam que "conteúdos atribuídos à descentralização, autonomia e à participação, que foram, naquele período (década de 1980), as bases do debate sobre a gestão democrática da educação, hoje pouco tem de democráticos, na medida em que se inserem em práticas governamentais de destituição de direitos".

$\mathrm{Na}$ análise das modalidades de ensino, destacamos evidências de mecanismos de quase-mercado na Educação Tecnológica e Formação Profissional e na Educação Especial.

Nas diretrizes para a Educação Tecnológica e Formação Profissional o PNE indica a necessidade de busca de recursos privados para financiamento da educação profissional.

É necessário também, e cada vez mais, contar com recursos das próprias empresas, as quais devem financiar a qualificação dos seus trabalhadores, como ocorre nos países desenvolvidos. A política de educação profissional é, portanto, tarefa que exige a colaboração de múltiplas instâncias do Poder Público e da sociedade civil (BRASIL, 2001).

A reengenharia entre oferta, financiamento e regulação dos serviços educacionais, explicitação máxima do quase-mercado, é tratada de maneira a atenuar as responsabilidades do Estado. Interessante destacar que a busca de tais parcerias se dá em nível local, onde a oferta se concretiza e, portanto, constituem mecanismo de gestão. 
Na educação especial, contudo, propõe-se a manutenção e ampliação da colaboração estatal, por meio de apoio financeiro, às entidades e organizações da sociedade civil que ofertam essa modalidade de ensino. Em consonância com os princípios de publicização da reforma do Estado, o PNE mantém a idéia de transferência da responsabilidade da oferta da educação especial para o terceiro setor, ainda que por meio de parcerias e convênios. Conforme já indicado, tal estratégia acaba por reafirmar a omissão do Estado.

Na seção dedicada ao Financiamento e Gestão, o PNE destacou a promoção da efetiva desburocratização e descentralização da gestão como diretriz a ser adotada. Emerge a idéia de gestão pautada na lógica de transferência de responsabilidades - na perspectiva de um Estado prescritivo e regulador, nos moldes daquele requerido e efetivado por meio da Reforma do Aparelho do Estado -, e orientada por referenciais do mercado - cuja desburocratização da gestão seria a grande recompensa.

O PNE indicou, nessa diretriz, a necessidade de repasse financeiro às unidades escolares a fim de que pudessem desenvolver o "essencial de sua proposta pedagógica e para as despesas de seu cotidiano" (BRASIL, 2001)

O texto prossegue tratando da gestão e indica:

(...)no exercício de sua autonomia, cada sistema de ensino há de implantar gestão democrática. Em nível de gestão de sistema na forma de Conselhos de Educação que reúnam competência técnica e representatividade dos diversos setores educacionais; em nível das unidades escolares, por meio da formação de conselhos escolares de que participe a comunidade educacional e formas de escolha da direção escolar que associem a garantia da competência ao compromisso com a proposta pedagógica emanada dos conselhos escolares e a representatividade e liderança dos gestores escolares (BRASIL, 2001). 
A gestão democrática foi revisitada e sua implantação foi associada à criação de conselhos e eleição de diretores. Nesse contexto, representatividade e competência técnica foram evidenciadas como condição para concretização dessa forma de gestão.

Importa destacar que os elementos que sustentam a proposta de efetivação da democratização da gestão são frágeis e insuficientes. Não será a criação de conselhos ou a eleição de diretores que tornarão a gestão de fato democrática, ainda que fossem garantidas a representatividade e competência técnica. Ao que nos parece, o proposto no PNE - e realizado nos últimos anos - foi uma gestão participativa, limitada ao acompanhamento do cumprimento de metas e resultados e à resolução de problemas, numa perspectiva de desoneração do Estado.

Em relação às diretrizes e metas específicas da Gestão, temos:

21. Estimular a criação de Conselhos Municipais de Educação e apoiar tecnicamente os Municípios que optarem por constituir sistemas municipais de ensino.

22. Definir, em cada sistema de ensino, normas de gestão democrática do ensino público, com a participação da comunidade.

23. Editar pelos sistemas de ensino, normas e diretrizes gerais desburocratizantes e flexíveis, que estimulem a iniciativa e a ação inovadora das instituições escolares.

24. Desenvolver padrão de gestão que tenha como elementos a destinação de recursos para as atividades-fim, a descentralização, a autonomia da escola, a eqüidade, o foco na aprendizagem dos alunos e a participação da comunidade.

28. Assegurar a autonomia administrativa e pedagógica das escolas e ampliar sua autonomia financeira, através do repasse de recursos diretamente às escolas para pequenas despesas de manutenção e cumprimento de sua proposta pedagógica.

38. Consolidar e aperfeiçoar o Sistema Nacional de Avaliação da Educação Básica - SAEB e o censo escolar.

39. Estabelecer, nos Estados, em cinco anos, com a colaboração técnica e financeira da União, um programa de avaliação de desempenho que atinja, pelo menos, todas as escolas de mais de 50 alunos do ensino fundamental e Médio.

40. Estabelecer, nos Municípios, em cinco anos, programas de acompanhamento e avaliação dos estabelecimentos de educação infantil (BRASIL, 2001) 
O PNE retomou as idéias centrais que permearam todo o seu texto naquilo que se referia à gestão, direta ou indiretamente, quais sejam:

- um modelo de gestão que contasse com a participação da comunidade, via conselhos, dando assim uma impressão de democracia,

- desresponsabilização do Estado por meio de estratégias de introdução de um modelo gerencial que prometia autonomia, descentralização e desburocratização da gestão;

- ênfase no controle e monitoramento de resultados.

Daquilo que foi analisado é possível considerar o PNE concebe a gestão educacional numa perspectiva gerencialista de busca de eficiência e produtividade por meio do monitoramento dos resultados e da responsabilização social.

\subsection{A gestão educacional no Plano de Desenvolvimento da Educação}

O Plano de Desenvolvimento da Educação - PDE, anunciado no ano de 2007 apresentou-se, conforme indicado no documento "Plano de Desenvolvimento da Educação: Razões, Princípios e Programas" (2007), como um plano executivo, como um conjunto de programas que visavam dar conseqüência às metas quantitativas estabelecidas no Plano Nacional de Educação, “mas os enlaces conceituais propostos tornam evidente que não se trata, quanto à qualidade, de uma execução marcada pela neutralidade" (BRASIL, 2007).

Em entrevista concedida à Revista Nova Escola em 2009, Dermeval Saviani considerou que o PDE não se constituía em um plano, além de não substituir o 
Plano Nacional de Educação, se tratava de "uma política pública, um conjunto de medidas e metas para o país, estabelecido por decreto" (SAVIANI, 2009, s.p).

Para Saviani (2009), o PDE era um ato do poder executivo, não uma lei, e estava ligado ao Plano de Aceleração do Crescimento (PAC), que envolvia ações em diferentes áreas da economia para impulsionar o crescimento econômico do país. “Como o PAC previa que cada ministério deveria ter um plano de atuação, o MEC reuniu um conjunto de ações que já desenvolvia, acrescentou algumas novas e assim nasceu o PDE” (SAVIANI, 2009, s.p.).

Para Minto (2009), o caráter híbrido do PDE gerou inúmeras críticas, das quais o autor se destacou algumas:

(...) antes de ser um plano coerente de ações, adequado à autoproclamada "visão sistêmica da educação", o PDE se apresenta como um verdadeiro amontoado de ações e programas: muitos já existentes, outros, pouco inovadores e, por fim, escassas ações efetivamente novas, a contar com aquelas que ainda estão em construção. (p.1)

Minto (2009) afirmou ainda que o PDE também não era satisfatório como "plano" efetivo. Os motivos para tal constatação seriam: i) o fato do PDE sobrepor o Plano Nacional de Educação, não levando em conta o disposto naquele plano, ii) financeiramente o PDE não representa garantias efetivas de ampliação dos recursos para a educação. “Às várias ações previstas, naquilo que pretensamente se ampliaria o raio de ação do MEC na educação pública, não corresponde uma devida ampliação financeira, sem a qual dificilmente se pode garantir condições objetivas para a sua implementação" (MINTO, 2009, p.1).

Para Camargo, Pinto e Guimarães (2008),

O que se pode concluir é que o PDE foi lançado mais de olho no marketing político do que na viabilidade financeira. E, o que é pior, serve para escamotear a discussão sobre o cumprimento da meta do Plano Nacional de Educação - este sim um plano de verdade, aprovado pelo Congresso Nacional - e sobre a derrubada do veto 
aposto por Fernando Henrique Cardoso em 2001 à ampliação dos gastos públicos com a educação para 7\% do PIB (p.829).

No documento "Plano de Desenvolvimento da Educação: Razões, Princípios e Programas" (2007), o PDE foi apresentado como um plano que, por meio de uma visão sistêmica de educação, visava superar as "falsas oposições" entre: educação básica e educação superior, educação infantil e os ensino fundamental e médio, ensino médio e educação profissional, alfabetização e educação de jovens e adultos, educação regular e educação especial.

Foi salientada, no documento, a importância da consolidação do regime de colaboração como condição para a implantação do Plano e execução das ações propostas. Tomou, também, como imperativos aos propósitos do Plano a responsabilização (accountability) e a mobilização social.

\begin{abstract}
Se a educação é definida, constitucionalmente, como direito de todos e dever do Estado e da família, exige-se considerar necessariamente a responsabilização, sobretudo da classe política, e a mobilização da sociedade como dimensões indispensáveis de um plano de desenvolvimento da educação. Com efeito, a sociedade somente se mobilizará em defesa da educação se a incorporar como valor social, o que exige transparência no tratamento das questões educacionais e no debate em torno das políticas de desenvolvimento da educação. Desse modo, a sociedade poderá acompanhar sua execução, propor ajustes e fiscalizar o cumprimento dos deveres do Estado (BRASIL, 2007).
\end{abstract}

Em síntese, o PDE sustentou-se em seis pilares: i) visão sistêmica da educação, ii) territorialidade, iii) desenvolvimento, iv) regime de colaboração, v) responsabilização e vi) mobilização social, entendidos como desdobramentos de princípios e objetivos constitucionais.

O PDE busca, de uma perspectiva sistêmica, dar conseqüência, em regime de colaboração, às normas gerais da educação na articulação com o desenvolvimento socioeconômico que se realiza no território, 
ordenado segundo a lógica do arranjo educativo - local, regional ou nacional (BRASIL, 2007)

Como plano executivo, o PDE articulou-se em torno de quatro eixos norteadores (educação básica, educação superior, educação profissional e alfabetização), compreendendo mais de 40 programas.

Para efeito de análise, e visando atender aos propósitos do presente trabalho, consideraremos apenas os eixos e programas propostos no PDE que guardem relação, ainda que indireta, com a questão da gestão da educação. Assim, buscaremos explorar no texto "Plano de Desenvolvimento da Educação: razões, princípios e programas" as possíveis explicitações das concepções e propostas ligadas à gestão. Analisaremos, ainda, o Decreto $n^{\circ} 6.094$ de 24 de abril de 2007, que dispôs sobre a implementação do Plano de Metas Compromisso Todos pela Educação, por entendermos que constitui elemento importante na regulamentação das ações propostas no PDE.

Quando discutiu o eixo Educação Básica, o texto "Plano de Desenvolvimento da Educação: razões, princípios e programas" destacou uma seção para tratar da avaliação (Avaliação e responsabilização: o IDEB). O texto indica que o PDE promoveu profunda alteração na avaliação da Educação Básica e estabeleceu inéditas conexões entre avaliação, financiamento e gestão que invocaram o conceito da responsabilização e mobilização social, este decorrente daquele.

Procurou demonstrar que o PDE ao instituir o Índice de Desenvolvimento da Educação Básica - IDEB, que propunha combinar os dados de desempenho escolar (demonstrados pelos resultados na Prova Brasil) com os resultados de rendimento escolar (fluxo apurado pelo censo escolar), conseguiu fixar metas de 
desenvolvimento educacional (de médio e longo prazo) para as escolas, redes de ensino e para o país. Segundo o texto, tais metas, em especial as intermediárias de curto prazo, possibilitariam a "visualização e acompanhamento da reforma qualitativa dos sistemas educacionais" (BRASIL, 2007)

O texto destacou, ainda, o estabelecimento da meta nacional de alcance do nível de desenvolvimento da educação básica dos países integrantes da Organização para a Cooperação e o Desenvolvimento Econômico (OCDE), a ser atingido no ano de 2021. Contudo, evidenciou as profundas distorções e variações entre os desempenhos verificados entre diferentes redes e escolas. Nesse contexto, evocou a promoção do enlace entre educação, ordenação do território e desenvolvimento econômico e social.

Destaca-se nessa análise uma concepção de gestão orientada para os resultados, cujo instrumento de controle é a avaliação. Trata-se tão somente da proposição de uma nova forma de mensuração que servirá como índice de calibragem dos sistemas, redes e escolas no atendimento das metas estabelecidas centralmente.

Previu-se uma ajuda da União aos “casos mais dramáticos” (BRASIL, 2007) por meio de repasses e transferências voluntárias com base em critérios entendidos como substantivos, em substituição ao repasse com base em critérios subjetivos.

Todavia, cabe destacar que, para além do "socorro" financeiro destinado às redes e às escolas que constituiriam os casos mais dramáticos revelados pelos resultados do IDEB, previu-se, ainda, a destinação de recursos adicionais aos entes que aderissem ao Compromisso Todos pela Educação, instituído pelo Decreto $\mathrm{n}^{\mathrm{o}}$ 6094/97. 
Segundo os critérios definidos pelo Decreto $n^{\circ}$ 6094/97, as adesões ao Compromisso norteariam o apoio suplementar e voluntário da União às redes públicas de educação básica. Tal apoio se daria por meio de ações de assistência técnica ou financeira e dentre os critérios que definiriam a prioridade de atendimento os resultados do IDEB e as possibilidades de incremento desse índice foram destacados.

Parece-nos clara a conexão entre avaliação, gestão e financiamento anunciada no texto. O modelo de avaliação proposto pelo PDE estaria a serviço da gestão gerencial que usa os resultados demonstrados como referencial para o aporte financeiro, numa perspectiva de premiação-punição. A divulgação dos índices e das notas serve ao conceito de responsabilização na medida em que imputa às escolas e às redes a culpa pelos resultados obtidos e, na mesma medida, patrocina a mobilização em busca do atendimento das metas impostas.

Para Casassus (2009), “a avaliação baseada em provas psicométricas referidas à norma está desenhada para selecionar e não para incluir” (p. 76). Para o autor, em contextos segmentados como são os sistemas educativos da América Latina, este tipo de avaliação promove a desigualdade. Não serve para melhorar a qualidade da educação, não serve para que os professores melhorem suas aulas, não são úteis para a gestão.

As obsevações do autor, contudo, referem-se a uma concepção de gestão muito distante daquela expressa no documento analisado, cujos objetivos, no limite, tendem a promover maior estratificação no conjunto das escolas, redes e sistemas de ensino, porque pautadas numa lógica onde a desigualdade é vista como natural.

Ainda no eixo da Educação Básica, o texto tratou do planejamento e da gestão educacional. Evidenciou-se, mais uma vez, a necessidade de consolidação do 
regime de colaboração pautado por um compromisso que seria consubstanciado em um plano de metas voltadas a mehoria da qualidade da educação.

O Decreto $n^{\circ}$ 6094/97 elencou 28 diretrizes que orientariam as ações do Plano de Metas Compromisso Todos pela Educação e que, segundo o texto, seriam reconhecidas e assumidas como compromisso de concretização pelos gestores por meio da adesão ao Plano.

Do ponto de vista operativo, seriam elaborados Planos de Ações Articuladas - PAR com vistas a identificar medidas apropriadas para a gestão do sistema, visando a melhoria da qualidade da educação básica. Os planos seriam construídos com a participação dos gestores e educadores locais, baseados em disgnósticos de caráter participativo.

Em nível escolar, propôs-se o PDE-Escola.

O PDE-Escola é uma ação de melhoria da gestão escolar fundamentada centralmente na participação da comunidade. No PDEEscola, a comunidade escolar é diretamente envolvida em um plano de auto-avaliação que diagnostica os pontos frágeis da escola e, com base nesse diagnóstico, traça um plano estratégico orientado em quatro dimensões: gestão, relação com a comunidade, projeto pedagógico e infra-estrutura. O plano estratégico define metas e objetivos e, se for o caso, identifica a necessidade de aporte financeiro suplementar. (BRASIL, 2007)

Há indícios claros de que a gestão da educação, denominada participativa, é tida como fundamental para o êxito do cumprimento das metas anunciadas pelo documento "Plano de Desenvolvimento da Educação: razões, princípios e programas" e definidas pelo decreto 6094/97. Há, também evidente vinculação entre liberação de recursos e cumprimento de metas.

Ainda que os entes interessados sejam chamados a aderir ao Compromisso Todos pela Educação, o apelo financeiro torna compulsória uma questão dada como voluntária, num contexto que, conforme aponta MINTO (2009), revela 
“verdadeira negociação com relação à qualidade da educação, cuja moeda é o IDEB. Daí porque a política de melhoria da qualidade reduz-se à melhoria dos índices educacionais". (s.p.)

De maneira sintética, podemos considerar que o PDE ao tratar da gestão educacional foi bastante coerente com o espírito que permeou as políticas educacionais das últimas décadas, explicitando um viés mercadológico que valoriza a gestão pela produtividade em nome da promoção da melhoria da qualidade.

Foi possível notar, no desenvolvimento deste capítulo, que a concepção de gestão educacional presente nos documentos analisados tem a avaliação como um instrumento fundamental para a consecução de seus objetivos. No discurso oficial a avaliação é tida como promotora de qualidade, produtora de igualdade, mecanismo de trasparência, instrumento de prestação de contas, entre outras tantas funções virtuosas atribuídas a ela, que, como já sabemos, não tem sido desempenhadas da forma como foram proclamadas.

No próximo capítulo analisaremos a avaliação educacional no contexto do quase-mercado. Para tanto, tomaremos como referência o estudo de três programas de avaliação: o Sistema Nacional de Avaliação da Educação Básica - SAEB, o Exame Nacional do Ensino Médio - ENEM e o Índice de Desenvolvimento da Educação Básica - IDEB.

Interessa-nos investigar quais as concepções de avaliação presentes nos documentos de criação e divulgação de tais programas e as possíveis evidências da presença de mecanismos de quase-mercado nesses modelos de política de avaliação. 


\section{CAPÍTULO 4}

A AVALIAÇÃO A SERVIÇO DO QUASE-MERCADO 
No campo educacional, a avaliação ganhou, nas ultimas décadas, espaço privilegiado na agenda das políticas para o setor. Entendida como importante elemento de aferição dos resultados educativos, a avaliação de rendimento escolar serviu aos propósitos do Estado reformado, na medida em que balizou sua tarefa reguladora e contribuiu para o cumprimento de sua função avaliadora.

Na década de 1990, o Ministério da Educação, por meio do Instituto Nacional de Pesquisas Educacionais - INEP -, promoveu a implantação de processos de avaliação de sistemas (ou avaliação em larga escala). Instalou-se, naquele período, o movimento de criação da cultura avaliativa por meio de três programas (ou políticas) de alcance nacional: o Sistema Nacional de Avaliação da Educação Básica - SAEB, o Exame Nacional do Ensino Médio - ENEM e o Exame Nacional de Cursos - ENC ${ }^{22}$.

O Brasil, é importante que se diga, seguiu a onda avaliativa que já havia se consolidado mundialmente. A esse respeito, vale destacar a valorização dada a programas como o PISA - Plano de Avaliação do Estudante - amplamente divulgado e frequentemente utilizado como parâmetro de comparação entre nações.

No ano de 2007 o governo federal criou o IDEB - Índice de Desenvolvimento da Educação Básica -, cuja formatação permitia a reunião em um só indicador de dois conceitos considerados “importantes para a qualidade da educação: fluxo escolar e médias de desempenho nas avaliações” (IDEB).

Nota-se o compromisso com a produtividade presente nos objetivos das avaliações em larga escala, o que revela, conforme já constatado, o perfil adotado nas políticas avaliativas das últimas décadas.

\footnotetext{
${ }^{22}$ A partir de 2004, por meio da Lei $n^{\circ} 10.861$, instituiu-se o Sistema Nacional de Avaliação Superior SINAES. O SINAES é formado por três componentes principais: a avaliação das instituições, dos cursos e do desempenho dos estudantes. O instrumento que avalia o desempenho dos Estudantes é denominado Exame Nacional de Desempenho do Estudante - ENADE que substituiu, portanto, o Provão do então ENC (Exame Nacional de Cursos)
} 
Este capítulo pretende, portanto, apresentar uma análise das políticas de avaliação educacional vigentes em âmbito nacional voltadas a aferir resultados da educação básica. A intenção é estudar os documentos oficiais de criação e divulgação ${ }^{23}$ das seguintes políticas ou programas:

- Sistema Nacional de Avaliação da Educação Básica - SAEB;

- Exame Nacional do Ensino Médio - ENEM;

- Índice de Desenvolvimento da Educação Básica - IDEB.

Por fim, vale destacar que o estudo a ser empreendido nesse capítulo visa entender os propósitos e o alcance das políticas avaliativas no contexto de relativização dos direitos sociais, processo que tem marcado a política educacional vigente e que revela o compromisso governamental com a mercantilização da educação.

\subsection{Sistema Nacional de Avaliação da Educação Básica - SAEB}

O Sistema de Avaliação da Educação Básica - SAEB - foi criado em 1988 e aplicado pela primeira vez em 1990. Tendo sido definido como um sistema de monitoramento contínuo, capaz de subsidiar as políticas educacionais, tinha como objetivo reverter o quadro de baixa qualidade e produtividade do ensino, caracterizado, essencialmente, pelos índices de repetência e evasão escolar (SOUZA e OLIVEIRA, 2003)

De corte amostral, o SAEB utilizava como um dos indicadores da avaliação o desempenho em provas aplicadas a alunos do ensino fundamental e médio.

\footnotetext{
${ }^{23}$ Consideraremos como documentos de divulgação os textos presentes nos sites oficiais (do Ministério da Educação e do INEP), cartilhas e demais materiais institucionais.
} 
Os objetivos apresentados quando da criação do SAEB evidenciavam uma postura de minimização e transferência da responsabilidade estatal para com os serviços educacionais, porém mantendo o controle e regulação, para o que o sistema de avaliação mostrava-se muito eficiente. Nessa mesma linha, a forma como seriam utilizados os resultados da avaliação promoveriam a competição entre escolas, de modo a estimulá-las a darem conta de seus próprios problemas.

Para Souza e Oliveira (2003),

O delineamento assumido pelo SAEB encontra respaldo em argumentos que se alinham na direção de justificar a avaliação como instrumento de gestão educacional, tais como: possibilidade de compreender e intervir na realidade educacional, necessidade de controle de resultados pelo Estado, estabelecimento de parâmetros para comparação e classificação de desempenhos, estímulo por meio da premiação, possibilidade de controle público do desempenho do sistema escolar (881).

Percebe-se, conforme já assinalado por Afonso (1998), o emprego da competição na gestão da educação pública, admitindo e assumindo uma lógica de mercado por meio da importação de modelos de gestão privada, cuja ênfase é posta nos resultados dos sistemas educativos. Desse modo, a avaliação surge como elemento essencial, pois possibilita a aferição, o controle e promove a responsabilização.

No ano de 20055 foi editada a Portaria $n^{\circ} 931$ que instituiu o Sistema de Avaliação da Educação Básica composto por dois processos de avaliação: a Avaliação Nacional da Educação Básica - ANEB - e a Avaliação Nacional do Rendimento Escolar - ANRESC - chamada de Prova Brasil.

A ANEB tinha proposta de aplicação por amostragem em cada unidade da federação e o ANRESC caráter censitário em nível de unidade escolar.

Os objetivos expressos na Portaria $n^{\circ}$ 931/2005 traziam para o ANEB: i) avaliar a qualidade, equidade e a eficiência da educação brasileira (indicado como 
objetivo principal); ii) coletar e sistematizar dados e produzir informações sobre o desempenho dos alunos do Ensino Fundamental e Médio, assim como sobre as condições intra e extra-escolares que incidem sobre o processo de ensino e aprendizagem - utilizando, para tanto, procedimentos metodológicos formais e científicos; iii) fornecer subsídios para formulação de políticas públicas educacionais, com vistas à melhoria da qualidade da educação e busca da comparabilidade entre anos e séries escolares, permitindo a construção de séries históricas.

A Portaria definiu que o ANEB teria uma periodicidade bianual e buscou assegurar que as informações produzidas não fossem utilizadas para identificar escolas, turmas, alunos, professores e diretores.

Para o ANRESC foram definidos os seguintes objetivos:

a) avaliar a qualidade do ensino ministrado nas escolas, de forma que cada unidade escolar receba o resultado global;

b) contribuir para o desenvolvimento, em todos os níveis educativos, de uma cultura avaliativa que estimule a melhoria dos padrões de qualidade e eqüidade da educação brasileira e adequados controles sociais de seus resultados;

c) concorrer para a melhoria da qualidade de ensino, redução das desigualdades e a democratização da gestão do ensino público nos estabelecimentos oficiais, em consonância com as metas e políticas estabelecidas pelas diretrizes da educação nacional;

d) oportunizar informações sistemáticas sobre as unidades escolares. Tais informações serão úteis para a escolha dos gestores da rede a qual pertençam. (BRASIL, 2005b)

Embora remodelado, o SAEB manteve os princípios que o caracterizaram como elemento importante da política educacional brasileira das últimas décadas, revelando o, já enunciado por Afonso (1999), "paradoxo do Estado neoliberal".

Senão vejamos: o ANEB ao eleger como objetivo principal a avaliação da qualidade, equidade e eficiência da educação brasileira, assumiu o 
compromisso com o controle não somente daquilo que seria avaliado, por meio da definição dos indicadores, mas dos resultados ou produtos.

Ainda que estivesse determinado que as condições intra e extraescolares que incidissem sobre o desempenho dos alunos seriam objeto de investigação, parece-nos pouco provável que tais questões tenham sido devidamente consideradas, dada a própria natureza e finalidades do processo.

Dourado (2005) define as condições intra e extra-escolares como sendo:

\begin{abstract}
um conjunto de variáveis (...) que intervêm no processo de produção do fracasso escolar indo desde as condições econômicas (desigualdades sociais, concentração de rendas, etc), culturais dos alunos e seu (des) compasso com a lógica de organização, cultura e gestão da escola (perspectiva institucional) até as dinâmicas e práticas pedagógicas utilizadas, em que se estruturam os processos ensinoaprendizagem propriamente ditos cujo balizamento encontra forte expressão na relação professor e aluno (p.2).
\end{abstract}

Importa destacar que num contexto de valorização da avaliação e dos resultados em que estão imersos sistemas, redes de ensino e escolas, as condições intra e extra-escolares que, de alguma forma, possam comprometer o desempenho e a posição daqueles avaliados, tendem a ser eliminadas, muitas vezes por meio de estratégias de seletividade e exclusão.

Em relação aos objetivos do ANRESC, chama-nos a atenção a preocupação com desenvolvimento de uma cultura avaliativa como condição de melhora dos padrões de qualidade e equidade, bem como a promoção do controle social sobre os resultados. A avaliação foi tida, ainda, como aquela capaz de promover a redução das desigualdades e a democratização da gestão do ensino público. 
Entendemos que a avaliação não é capaz de cumprir com tais objetivos, ficando, portanto, à mercê do uso que as políticas vigentes fazem de seus resultados. Conforme indicam Sousa e Lopes (2010)

\begin{abstract}
Os significados que assumem as avaliações, seja para os gestores das instâncias centrais e intermediárias responsáveis pela administração da educação, seja para as instituições de ensino, vão depender, essencialmente, do uso que se fizer de seus resultados. As decisões deles decorrentes tanto podem servir a propósitos de democratização, como podem potencializar iniciativas que intensifiquem desigualdades e levem à exclusão (p.55)
\end{abstract}

Entendemos, contudo, que o que está em jogo é um sistema que impõe normas, dita regras e controla resultados. Escolas e professores são pressionados, seja pela via da punição ou da premiação, a demonstrarem resultados satisfatórios. Tais resultados, entretanto, servem mais a um projeto de educação voltado para a produtividade e melhora de índices de escolarização, que a um modelo de educação comprometido com a universalização da qualidade, igualdade de oportunidades, inclusão.

Em entrevista concedida em 2006 à revista portuguesa "A Pagina da Educação", Almerindo Janela Afonso analisou as pressões sofridas pelas escolas e professores diante da imposição de uma avaliação que em muito se assemelha aos modelos implantados no Brasil. Afonso, de início, concordava com a tese de que a construção de uma sociedade democrática voltada para a concretização dos princípios de transparência e participação depende do conhecimento daquilo que ocorre nas suas instituições, nomeadamente nas escolas.

Mas não é com a utilização de mecanismos de controlo, fortemente centralizados como os exames nacionais, que se promove uma 
prestação de contas e responsabilização sérias. Os exames têm, entre outras coisas, servido para satisfazer os neoconservadores que exigem que o Estado seja (nomeadamente através da avaliação, do currículo, da gestão e da actividade docente) mais controlador, fiscalizador, vigilante e disciplinador, e, simultaneamente, os exames têm também servido para satisfazer os neoliberais que querem, nomeadamente através da publicitação dos respectivos resultados académicos, induzir efeitos de mercado no sistema educativo, ajudando assim a promover formas de competição espúria (isto é, alheia às consequências mais nefastas dos rankings) e introduzir políticas de privatização e de mercantilização da educação que, entre outros efeitos, desvalorizam a escola pública enquanto escola publicamente comprometida com os princípios da igualdade real de oportunidades para todos, da "pluralidade de excelências", da justiça e da cidadania democrática (AFONSO, 2006, s.p.)

O SAEB constitui-se numa iniciativa de organização de um sistema de avaliação educacional, cujas características acabam por revelar a natureza e os compromissos da política educacional em que está inserido.

Examinaremos, a seguir, o Exame Nacional do Ensino Médio ENEM, outro exemplo de política avaliativa brasileira.

\subsection{Exame Nacional do Ensino Médio}

O Exame Nacional do Ensino Médio - ENEM - foi criado no ano de 1998 para ser aplicado anualmente aos alunos concluintes e egressos do ensino médio.

Entre os objetivos fundamentais do Exame, destacou-se a avaliação do desempenho do aluno ao término da escolaridade básica, para aferir o desenvolvimento de competências fundamentais ao exercício pleno da cidadania.

A avaliação consistia na aplicação de uma única prova que abrangeria as várias áreas de conhecimento em que se organizavam as atividades da escolaridade básica no Brasil (BRASIL, 1999a). Segundo o Documento Básico de 1999 que 
apresentou o ENEM, concebeu-se uma matriz com a indicação das competências e habilidades que seriam avaliadas. Como referência foram utilizados a LDB, os Parâmetros Curriculares Nacionais - PCN, a Reforma do Ensino Médio, os textos que sustentavam a organização curricular em Áreas de Conhecimento e as Matrizes Curriculares de Referência para o SAEB.

Como objetivos específicos, foram elencados:

a) oferecer uma referência para que cada cidadão possa proceder à sua auto-avaliação com vista às escolhas futuras, tanto em relação ao mercado de trabalho quanto em relação à continuidade de estudos; b) estruturar uma avaliação da educação básica que sirva como modalidade alternativa ou complementar aos processos de seleção nos diferentes setores do mundo do trabalho;

c) estruturar uma avaliação da educação básica que sirva como modalidade alternativa ou complementar aos exames de acesso aos cursos profissionalizantes pós-médios e ao ensino superior (BRASIL, 1999a)

Importante destacar que a adesão ao ENEM tinha caráter voluntário,

todavia, tanto o material informativo elaborado para divulgação do Exame, quanto o Documento Básico buscavam convencer os concluintes e egressos do Ensino Médio sobre a importância da participação. Com um discurso assentado na valorização dos resultados da avaliação como balizador de escolhas futuras, tanto em relação à inserção no mercado de trabalho, quanto à continuidade de estudos, o ENEM prometia mostrar aos estudantes e egressos as áreas em que precisavam "caprichar ainda mais para ter sucesso profissional” (BRASIL, 1999b).

Se os objetivos fundamentais expressos no Documento Básico apontavam para uma avaliação do desempenho que buscava aferir o desenvolvimento de competências fundamentais ao exercício pleno da cidadania e os objetivos específicos tratavam de criar referências para escolhas futuras - construir modalidades alternativas ou complementares para seleção do mercado e de demais níveis e 
modalidades de ensino -, podemos considerar, portanto, que o ENEM tinha a avaliação como um fim em si mesma.

Não havia, ao que nos parece, preocupação ou compromisso com a utilização dos resultados aferidos como instrumento para análise e correção de rotas, tampouco proposição de políticas públicas de promoção de melhoria desse nível de ensino. Tratava-se de uma avaliação de produto final (da Educação Básica); desse modo, nada poderia ser feito em relação ao aluno que demonstrasse, por meio dos resultados obtidos, deficiências legítimas.

Nesse sentido Souza e Oliveira (2003, p.82) argumentavam que “ trata-se (...) de uma medida de resultado final, interpretada em uma perspectiva individualizada, desconsiderando as condições do sistema de ensino que, sem dúvida, induzem a produção de "competências" ou "incompetências" nos alunos".

O Exame pretendia, ainda segundo os autores, se legitimar como mecanismo de referência a processos seletivos, que tão somente classificava alunos, com base nas competências individuais, medidas pelos testes.

O ENEM, contudo, não conseguiu atingir, nos primeiros anos de sua implantação, um número significativo de estudantes e egressos, talvez porque os objetivos da avaliação apresentados não interessassem nem mesmo a eles.

No ano de 2000, quando as instituições de ensino superior começaram a utilizar os resultados do exame como parte do processo seletivo, houve um aumento no número de candidatos. Em 2001, novo aumento se deu em função da instituição da gratuidade do Exame para os alunos das escolas públicas e para aqueles que demonstrassem impossibilidade de pagamento da taxa de inscrição. Já a partir de 2004 o 
aumento verificado teve relação com o fato de o governo federal passar a utilizar o ENEM como critério para concessão de bolsas do Programa Universidade para Todos (PROUNI).

A evolução das inscrições, portanto, esteve diretamente ligada à utilidade verificada por aqueles que se submeteriam ao Exame.

Em 2009, o MEC, por meio do Instituto Nacional de Estudos e Pesquisas Educacionais Anísio Teixeira - INEP, estabeleceu nova sistemática para realização do ENEM, por meio da edição da Portaria nº 109, de 27/05/2009. Definindo o ENEM como procedimento de avaliação do desempenho escolar e acadêmico dos participantes, cuja função seria aferir o desenvolvimento de competências e habilidades fundamentais ao exercício da cidadania, a Portaria indicou os objetivos específicos do Exame, muitos dos quais já presentes nos documentos de sua criação.

Contudo, alguns objetivos diferenciam-se daqueles já mencionados, dos quais destacamos:

\footnotetext{
IV - possibilitar a participação e criar condições de acesso a programas governamentais;

V - promover a certificação de jovens e adultos no nível de conclusão do ensino médio nos termos do artigo $38, \S \S 1^{\circ}$ e $2^{\circ}$ da Lei $n^{\circ}$ 9.394/96 - Lei das Diretrizes e Bases da Educação Nacional (LDB); VI - promover avaliação do desempenho acadêmico das escolas de ensino médio, de forma que cada unidade escolar receba o resultado global;

VII - promover avaliação do desempenho acadêmico dos estudantes ingressantes nas Instituições de Educação Superior; (BRASIL, 2009A)
}

O uso do ENEM como instrumento de credenciamento e acesso a programas governamentais já fora previsto e materializado no Programa Universidade para Todos (PROUNI), que vinculava a concessão de bolsas em Instituições de Ensino Superior privadas ao desempenho obtido pelos alunos no Exame. 
Propôs-se, também, na reestruturação do ENEM, a promoção da certificação de jovens e adultos em nível de conclusão do ensino médio, o que provavelmente provocará a substituição do Exame Nacional para Certificação de Competências de Jovens e Adultos (Encceja).

Por fim, os objetivos relacionados à avaliação de desempenho dos alunos e das escolas de ensino médio apontam duas intenções: i) a de divulgar os resultados obtidos pelas escolas contribuindo para os processos de monitoramento e controle de resultados, além do compromisso com a prestação de contas à sociedade, há tempos assumido pelo governo Lula (e também por seu antecessor) ${ }^{24}$; ii) a legitimação do Exame como mecanismo de seleção para ingresso no Ensino Superior.

Percebe-se uma considerável ampliação dos objetivos do ENEM. Na mesma medida, percebe-se, cada vez mais, um explícito compromisso com um projeto de educação voltado para o produto, para o qual o ENEM servirá como elemento fomentador de controle, acompanhamento e competição.

Vale destacar, nesse sentido, o texto da nota técnica do Exame do ano de 2008 .

(...) o conhecimento do desempenho médio dos estudantes por escola, além de constituir um direito da sociedade, é um elemento que contribui para a melhoria do ensino. A divulgação das notas médias do Enem por escola oferece diversas possibilidades para a compreensão do perfil e do desempenho dos jovens estudantes ao término da escolaridade básica e ainda funciona como um elemento de mobilização em favor da melhoria da qualidade do ensino e auxilia professores, diretores e demais dirigentes educacionais na identificação de deficiências e de boas práticas no âmbito da escola. (2009b)

\footnotetext{
${ }^{24}$ Nesse particular é preciso considerar que, por ter caráter voluntário, foram criados mecanismos visando garantir a precisão dos dados divulgados - definição de critérios mínimos de participação e corretor de participação (que simulava a nota final se todos os concluintes da escola tivessem realizado a prova)
} 
A difusão de idéias que visam atribuir a avaliação educacional o poder de promover qualidade, instituir um necessário controle social e incentivar a mobilização social em favor da melhoria da escola, constituem estratégias de naturalização e legitimação de mecanismos de gestão gerencial na educação pública. A supervalorização e uso da avaliação já consagram tal estratégia, na medida em que, de plano, ao divulgar seus resultados promovem a competição, padrão básico do comportamento organizacional.

É justamente nesse movimento de idas e vindas ao mercado que se configura o quase-mercado educacional, caracterizado justamente pelo modo como as instituições públicas passam a operar como instituições do setor privado. Nesse sentido, a contribuição da avaliação é evidente e eficaz.

Retomaremos, por fim, a consideração de um fator que julgamos essencial para o entendimento das políticas de avaliação educacional no contexto atual, o uso dos resultados aferidos. Entendemos que a avaliação é uma importante etapa da política, além de forma legítima de o Estado identificar avanços, retrocessos, enfim "controlar" os processos e os impactos de sua implementação; todavia o modelo avaliativo assumido nos últimos anos serviu muito mais para legitimar a posição do Estado prescritivo e regulador.

$\mathrm{Na}$ seção seguinte analisaremos o Índice de Desenvolvimento da Educação Básica - IDEB, buscando verificar em que medida sua adoção colaborou para a consolidação da concepção de avaliação verificada até o momento. 


\section{3 Índice de Desenvolvimento da Educação Básica - IDEB}

O índice de Desenvolvimento da Educação Básica - IDEB - foi lançado no ano de 2007 paralelamente ao lançamento do Plano de Desenvolvimento da Educação.

O Decreto $n^{\circ}$ 6.094/2007 dedicou um capítulo para tratar do IDEB, determinando que o Índice serviria de base para aferição da qualidade da Educação Básica. Estabeleceu como indicadores que comporiam o índice a taxa de rendimento escolar (aprovação, retenção e evasão), verificada no Censo Escolar, e os dados de desempenho dos alunos, obtidos por meio da aplicação do SAEB.

Determinou-se no Decreto que o IDEB seria o indicador objetivo para a verificação do cumprimento das metas fixadas no termo de adesão ao Compromisso Todos pela Educação.

No ano de lançamento do IDEB, o INEP publicou um documento de apresentação intitulado "Índice de Desenvolvimento da Educação Básica (IDEB)". O documento buscou justificar a necessidade de criação do Índice e as vantagens da sua aplicação.

Para Fernandes (2007), a questão do acesso à educação no Brasil estaria praticamente resolvida; contudo era nos altos índices de repetência, na elevada proporção de jovens que abandonavam a educação básica e na baixa proficiência dos estudantes nos exames padronizados que residiam os maiores problemas da educação. Sendo assim, nas palavras do então presidente, "um indicador de desenvolvimento educacional deveria combinar tanto informações de desempenho em exames padronizados como informações sobre fluxo escolar" (p.7). 
Na lógica defendida pelo autor, a combinação dos dois indicadores (fluxo escolar e desempenho nos exames) seria necessária, na medida em que nem sempre a melhora (ou piora) de um deles implicaria na melhora (ou piora) de outro. Significa considerar que a melhora do fluxo escolar não representaria, necessariamente, a melhora do desempenho nos exames padronizados, e vice-versa.

De acordo com Camargo, Pinto e Guimarães (2008), os índices de promoção - um dos referenciais do rendimento escolar - seriam passíveis de alteração através de medidas de ordem administrativa, como a introdução da progressão continuada, o que não geraria, necessariamente, impacto positivo na qualidade do ensino oferecido.

Da mesma forma, o empenho em alcançar desempenhos significativos nos exames padronizados poderia resultar numa maior seletividade no interior do sistema, o que tenderia a gerar um aumento nos índices de retenção e evasão escolar.

Todavia, cabe ressaltar que a pura e simples combinação de tais indicadores não garante um diagnóstico preciso da realidade educacional brasileira. Isto

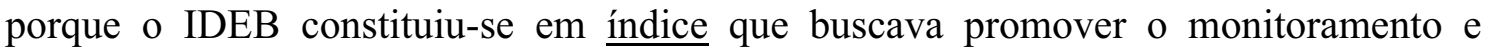
medição do progresso dos programas educacionais em relação às metas e resultados fixados. Além disso, a definição dos indicadores de desempenho passíveis de aferição foram (e tem sido) tarefa única e exclusiva das autoridades educacionais, que usavam como referência para tal definição o quão precisos poderiam ser os indicadores no monitoramento do alcance dos objetivos estratégicos traçados previamente.

O IDEB, portanto, configurou-se como mais uma (entre tantas) ferramenta de regulação do Estado (e do mercado). 
Entendido como um indicador objetivo de verificação de metas, o Índice seria calculado em uma escala de 0 a 10, sendo que, para os propósitos a que se destinava, deveria apresentar variação positiva, até alcançar, no ano de 2021 a média 6,0 (média dos países membros da OCDE). A meta nacional (6,0 em 2021), contudo, nortearia o cálculo das trajetórias intermediárias individuais do índice para o país, estados, municípios e escolas.

O ponto de partida para o cumprimento das metas foi à definição do IDEB inicial, produto dos resultados de desempenho apresentados na Prova Brasil do ano de 2005 e das taxas de aprovação relativas ao mesmo ano, obtidas com base nos Censos Escolares de 2005 e 2006. Estableceu-se, também, a média que deveria ser atingida no ano de 2007 e propuseram-se metas intermediárias em âmbito nacional, estadual, municipal e para escolas.

De posse dos dados verificados e das metas definidas, o MEC intensificou campanha nacional de divulgação do Índice, conjugada a uma forte propaganda institucional visando dar legitimidade à política e valorizar o órgão e o governo.

Foi produzida uma peça publicitária, que foi veiculada na TV aberta, onde uma atriz com uma espécie de ponta de seta na mão aparecia no alto de uma escada. Ao seu lado números eram projetados, indicando a passagem dos anos. Á medida em que desenvolvia sua fala ${ }^{25}$, a atriz descia os degraus e, de forma

\footnotetext{
25 "Para medir a aprendizagem dos alunos do ensino básico, o Ministério da Educação passou a usar um novo indicador: o IDEB - Índice de Desenvolvimento da Educação Básica, que é o resultado da combinação das notas da Prova Brasil e das taxas de aprovação dos estudantes. O primeiro IDEB apurado em 2005 nas séries iniciais era de 3,8, muito distante da média 6,0 dos países desenvolvidos. Agora a distância diminuiu, em dois anos o novo IDEB brasileiro apurado em 2007 saltou para 4,2. Mas ainda há um longo caminho a percorrer. Conheça o IDEB do seu município e da sua escola e saiba como participar para melhorar a educação dos brasileiros".
} 
concomitante, os anos se alteravam, de forma crescente. Uma curva descendente era desenhada demarcando um declínio, que, ao que nos parece, estaria relacionado à qualidade da educação. Cabe esclarecer que no início da peça, quando a atriz aparecia no topo da escada, o ano projetado era 1930. Ao alcançar o final da escada, o ano registrado era 1948 e a curva se transformou em reta, indicando a manutenção dos índices durante um período que se encerraria em 1979. A partir desse ponto a atriz passou a subir uma outra escada até alcançar, após poucos degraus, o ano de 2005 . No início da subida da nova escada uma nova curva, agora ascendente, apareceu, indicando melhora de índices. A atriz parou por algum tempo diante do ano de 2005 e apontou para o índice 3,8, fazendo menção à nota do IDEB para aquele ano. Depois apontou para o alto da escada onde se via registrado o índice 6,0 , mostrando ser aquela a meta a ser alcançada. A atriz continuou a subir até parar diante do índice 4,2 explicando ter sido aquela a nota obtida no ano de 2007. A atriz apareceu subindo mais alguns degraus indicando o longo caminho que ainda precisava ser percorrido e, finalmente, colocando a ponta da seta no final da curva ascendente conclamou os espectadores a conhecerem o IDEB das escolas e as formas de participar para a melhoria da educação.

A par das intenções de promoção governamental, é preciso destacar a mensagem passada acerca da necessidade do uso do Índice, da supervalorização da avaliação como mecanismo de legitimação de políticas (propostas e materializadas), e da idéia de que a qualidade seria promovida por meio do monitoramento dos resultados. 
Embora se propague a idéia de que o Estado assumiu compromissos com a melhoria da qualidade da educação, por meio do estabelecimento de metas e de ações para seu atingimento, parece-nos que a lógica produtivista é muito presente.

Se de um lado temos programas de avaliação educacional que servem para classificar escolas, distribuir recursos, selecionar alunos e trabalhadores, punir e premiar, de outro temos as escolas e professores pressionados a obter bons resultados nesses processos avaliativos. Ao professor, em especial, tem sido reservado, nesse contexto, papel fundamental para o cumprimento da política educacional. Esse papel, que se materializa por meio do exercício da profissão, tem sido imposto por meio da determinação de tarefas e funções e passam, necessariamente, pela formação inicial e continuada que, por seguirem as diretrizes e normas de alcance nacional, carregam as concepções de educação que se pretende implantar.

No capítulo a seguir, analisaremos as políticas de formação de professores e a emergência dos mecanismos de quase-mercado educacional. 


\section{CAPÍTULO 5}

O QUASE-MERCADO NA FORMAÇÃO DE PROFESSORES 
As políticas de formação de professores no Brasil iniciadas na década de 1990 destacavam-se por seu caráter utilitarista. De um lado, assumiram um compromisso que vislumbrava muito mais a adequação/melhoria dos indicadores educacionais ligados à titulação do quadro docente - institucionalizada pelo novo corpo legal (LDB) -, do que a implantação de um projeto global de formação e profissionalização docente (DOURADO, 2001). Por outro lado, promoveram uma formação orientada para o resultado, numa perceptiva de educação produtivista.

Segundo Santos (2004), trata-se da formação de professores na cultura do desempenho. Referenciados no modelo de Estado avaliador, os processos de formação de professores têm se pautado pela idéia de que os docentes (e as escolas) são os grandes responsáveis pelos resultados obtidos por seus alunos - materializados nos testes de desempenho a que são submetidos. Nesse sentido, preparam-se professores que, ao longo de sua atividade docente, têm nos indicadores de qualidade dos testes de desempenho o alvo de seu trabalho.

Nesse tipo de cultura, ainda segundo Santos, o que não pode ser medido por meio de indicadores de desempenho, deixa de ter importância. Assim, a educação, de modo geral, e o professor, em particular, são chamados a responder pelos resultados obtidos, de forma que o que passa a ter importância é o produto final, ou na linguagem do mercado - de onde se origina a matriz conceitual, ideológica e estrutural desse processo - a produtividade.

No que se refere à formação docente, os mecanismos de quasemercado tem orientado a ação Estatal e produzido uma série de estratégias de ajustamento/conformação ligadas à profissionalização do professor. Exemplo disso é a questão da vinculação (subordinação) da educação às demandas do mercado, que, 
embora não seja assunto novo, tem alterada, nesse novo contexto, a forma de manejo e acompanhamento dessa "articulação".

Para Kuenzer (1999),

Até a LDB, havia estreita articulação entre formação e emprego, assumindo o Estado, segundo o modelo de bem-estar social, a regulação da relação entre instituições formadoras e mercado de trabalho pelo controle no processo, dos currículos, da certificação e da qualidade da oferta, estabelecendo critérios rigorosos de qualidade que se constituíam em condições para autorização de funcionamento e reconhecimento de cursos. Segundo o entendimento do Banco Mundial, a transferência das atribuições do Estado para a esfera privada exige duas ordens de providências: a articulação dos cursos de formação às demandas do mercado e a "flexibilização" do modelo tradicional de universidade, que articula ensino e pesquisa, acompanhada do rebaixamento dos critérios de qualidade, transferindo o controle do processo para o do produto, de modo a estimular a iniciativa privada pela redução dos custos de formação (p. 178-179).

De maneira sintética, e acompanhando o raciocínio da autora, as políticas para formação de professores oportunizaram modelos de formação aligeirada, de baixo custo e, muitas vezes, terceirizada.

Ante a esse quadro, importa-nos compreender de forma mais aprofundada como os mecanismos de quase-mercado se manifestam nas políticas de formação de professores. Para isso, realizaremos um estudo dos documentos que ditam as diretrizes de formação de professores, com foco na educação básica.

Serão analisados os seguintes documentos:

- Lei $n^{0}$ 9394, de 20 de Dezembro de 1996 - Estabelece as diretrizes e bases da educação nacional;

- Resolução CNE/CP n ${ }^{\circ}$, de 18 de fevereiro de 2002 - Institui Diretrizes Curriculares Nacionais para a Formação de Professores da Educação Básica, em nível superior, curso de licenciatura, de graduação plena; 
- Plano de Desenvolvimento da Educação - PDE.

\subsection{A formação de professores no contexto da Lei $\mathbf{n}^{\circ}$ 9394, de 20 de Dezembro de 1996 - Estabelece as diretrizes e bases da educação nacional}

A Lei de Diretrizes e Bases da Educação Nacional - LDB, promulgada em 1996 dedicou um capítulo para tratar dos profissionais da educação. Foram abordadas questões relativas à formação dos profissionais da educação e dos docentes, espaços de formação e carreira do magistério.

Quanto às categorias contempladas, o texto de $1996^{26}$ não definiu precisamente quais seriam os profissionais da educação. Tal imprecisão deu margem para que diferentes entidades e profissionais passassem a reivindicar benefícios e vantagens antes exclusivos de docentes, coordenadores e demais gestores educacionais.

No que tange aos aspectos da formação, a Lei definiu como finalidades "atender aos objetivos dos diferentes níveis e modalidades de ensino e às características de cada fase do desenvolvimento do educando" (BRASIL, 1996), tendo como fundamentos "a associação entre teorias e práticas, inclusive mediante a capacitação em serviço e o aproveitamento da formação e experiências anteriores em instituições de ensino e outras atividades”. (BRASIL, 1996)

Para Gatti (2000), o texto da Lei evidenciava a preocupação com a superação da dicotomia teoria/prática na formação dos docentes. A autora, contudo, argumentou que diante de um texto que ao mesmo tempo era enxuto, amplo e flexível,

\footnotetext{
${ }^{26}$ A Lei n $\mathrm{n}^{\circ}$ 12.014, de 06 de agosto de 2009 alterou o artigo 61 da Lei de Diretrizes e Bases da Educação Nacional, cuja finalidade era discriminar as categorias de trabalhadores considerados profissionais da educação.
} 
caberia questionar se tal flexibilidade seria mantida diante de uma possível normatização (excessiva) por parte dos Conselhos de Educação. Nesse particular cabe esclarecer que o fundamento de articulação entre teoria e prática definido pela LDB não se concretizou na realidade dos cursos de formação, muito menos pela via da normatização do que pela própria improvisação das instituições formadoras.

Em relação à capacitação em serviço, é possível considerar que tal preceito reafirmou a tendência utilitarista e instrumental da política de formação de professores. Segundo Veiga (1998), tal modelo poderia ser compreendido como formação de executores do ensino efetivo, podendo substituir a "sólida fundamentação teórica pelo ativismo em sala de aula e outras atividades não-docentes” (p.82).

Ao contemplar a capacitação em serviço e o aproveitamento da formação e experiências anteriores (em instituições de ensino e outras atividades) como forma de associar teoria e prática nos processos de formação, o legislador deu margem a diferentes e enviesadas interpretações, conforme previsto por Brzezinski (1998). Tais interpretações se manifestaram na supervalorização da prática e das experiências anteriores, em detrimento de um processo formativo baseado, também, numa sólida e necessária base teórica.

Dourado (2001), nesse sentido, identificou a articulação das políticas educacionais nacionais à tese defendida pelo Banco Mundial, mentor das reformas educativas latino-americanas, na qual eram incentivadas a formação em serviço e o aligeiramento da formação inicial, entendidos como capacitação pedagógica de cunho estritamente técnico.

Em relação aos espaços de formação, a LDB criou os Institutos Superiores de Educação - ISE - que tinham por objetivo manter cursos de formação de 
professores para a educação básica (inclusive normal superior para docentes da educação infantil e séries iniciais do ensino fundamental), programas de formação pedagógica e programas de educação continuada.

Segundo Freitas (2002) os ISE foram caracterizados como instituições de caráter técnico-profissionalizante que tinham como objetivo principal "a formação de professores com ênfase no caráter técnico instrumental, com competências determinadas para solucionar problemas da prática cotidiana" (p.143), nas palavras da autora, um prático.

Criados como instituiçães de caráter técnico-profissionalizante, de
baixo custo, a expansão exponencial desses novos espaços de
formação objetiva, com raras exceções, responder às demandas de
grande parcela da juventude atual por educação em nível superior,
oferecendo-lhes uma qualificação mais ágil, flexível, adequada aos
princípios da produtividade e eficiência e com adequação às
demandas do mercado competitivo e globalizado. (FREITAS, 2003,
p.144)

Cabe acrescentar que a criação dos ISE alavancou, ainda mais, a expansão do setor privado na educação. Assim, e apenas em relação aos espaços de formação, a Lei foi capaz de promover: i) o aumento da atuação da iniciativa privada, em detrimento da esfera pública, ii) a separação entre ensino e pesquisa, ao retirar da universidade a tarefa de formar professores e transferi-la para os ISE, cujo caráter já foi destacado, iii) intensificação de uma formação superficial, baseada na construção de competências básicas e úteis aos propósitos da política educacional vigente, marcada pela ênfase na eficiência e produtividade.

A Lei determinou como formação mínima para atuação no magistério da educação básica aquela realizada em nível superior, admitindo, contudo a formação em nível médio para os que viessem a atuar na educação infantil e séries iniciais do ensino fundamental. A princípio o que se depreendeu da leitura da norma foi que a idéia 
básica defendida era a da valorização da formação superior. Tal interpretação encontrou respaldo no artigo 87 das Disposições Transitórias.

Art. 87. É instituída a Década da Educação, a iniciar-se um ano a partir da publicação desta Lei.

(...)

$\S 4^{\circ}$. Até o fim da Década da Educação somente serão admitidos professores habilitados em nível superior ou formados por treinamento em serviço. (BRASIL, 1996)

Todavia, o que parecia ser um avanço em termos de formação, acabou por provocar uma espécie de "caça” ao diploma que, para Freitas (2002), configurou-se em um processo de desprofissionalização do magistério.

(...) os professores têm sido levados a freqüentar cursos de qualidade duvidosa em grande parte pagos por eles. Em vários estados tais cursos são, em geral, uma demanda das prefeituras que os terceirizam ou "contratam" as IES - públicas ou privadas -, as quais realizam processo seletivo especial de modo que possam atender a esta demanda específica (p.148).

Para a autora, tratou-se de um precário processo de certificação/diplomação e não qualificação do magistério para o exercício profissional.

Sobre a carreira a Lei determinou que os sistemas de ensino promoveriam a valorização dos profissionais da educação, por meio de estatutos e planos de carreira que assegurariam-lhes ingresso exclusivamente por concurso público de provas e títulos, aperfeiçoamento profissional continuado, inclusive com licenciamento periódico remunerado para tal fim; piso salarial profissional, progressão funcional baseada na titulação ou habilitação, e na avaliação do desempenho; período reservado a estudos, planejamento e avaliação, incluído na carga de trabalho e condições adequadas de trabalho.

Ainda que a Lei tenha buscado garantir minimamente a valorização dos profissionais do magistério e definir a criação de planos de carreira, é sabido que o descompromisso das autoridades educacionais tratou de transformar um possível benefício 
em instrumento de pressão e regulação do professor; exemplo disso são os processos de avaliação do desempenho do professor.

A avaliação de desempenho docente, a exemplo das outras modalidades de avaliação presentes na política educacional vigente (desempenho de alunos, desempenho dos sistemas, desempenho das escolas), tem como objetivo principal o controle sobre os resultados e a supervisão, na busca por maior eficiência e produtividade. Nesse sentido, ainda que não se concretize como instrumento de certificação de competência profissional, a avaliação de desempenho docente tem servido aos propósitos gerenciais da gestão educacional, numa perspectiva de premiação e punição, principalmente quando atrelada aos processos de progressão funcional.

Nesse particular o uso da avaliação de desempenho tenderia a naturalizar uma distribuição não igualitária de benefícios, uma vez que nem todos os ocupantes da mesma categoria seriam contemplados. A avaliação, assim, atenderia aos propósitos de racionalização orçamentária denunciada por Souza (2003).

A respeito disso, e a título de ilustração, passaremos a verificar as recentes políticas implantadas no Estado de São Paulo que valorizam a avaliação de resultados como parâmetro para distribuição de benefícios, numa perspectiva de valorização da carreira de viés racionalista e mercadológico.

No ano de 2008 o governo paulista, por meio da Resolução $\mathrm{n}^{\circ} 74$, instituiu o Programa de Qualidade da Escola (PQE) que se constitui em um programa de avaliação e monitoramento de resultados, cujos indicadores são o fluxo escolar (evasão, retenção e promoção) e o desempenho dos alunos no Sistema de Avaliação de Rendimento Escolar do Estado de São Paulo - SARESP. O PQE previu a criação de um índice (resultante da combinação dos indicadores de fluxo escolar e desempenho dos estudantes) que serviria de base para o atendimento de metas de evolução definidas para cada escola. 
Paralelamente foi aprovada a Lei Complementar $n^{0} 1078 / 2008$ que instituiu a Bonificação por Resultados - BR, no âmbito da Secretaria da Educação. Tal bonificação, a ser paga a professores e funcionários, decorreria do cumprimento das metas estabelecidas pelo PQE e, conforme texto da Lei, visava à melhoria e ao aprimoramento da qualidade do ensino público.

Segundo a Lei, as unidades escolares e administrativas seriam submetidas à avaliação destinada a apurar os resultados obtidos em cada período, de acordo com os indicadores e metas estabelecidos. Tal avaliação seria baseada em indicadores que refletiriam o desempenho institucional no sentido da melhoria da qualidade do ensino e da aprendizagem, podendo ser considerados indicadores de desenvolvimento gerencial e de absenteísmo.

Foram estabelecidos critérios que deveriam ser considerados na definição dos indicadores de avaliação de desempenho das unidades de ensino e administrativas, a saber:

1 - alinhamento com os objetivos estratégicos da Secretaria da Educação;

2 - comparabilidade ao longo do tempo;

3 - mensuração objetiva e apuração a partir de informações previamente existentes;

4 - publicidade e transparência na apuração. (SÃO PAULO, 2008)

O valor da Bonificação por Resultados - BR, pago anualmente, poderia alcançar até $20 \%$ da retribuição mensal do servidor relativo ao período de avaliação.

Em relação ao exemplo analisado parece-nos razoável considerar que o desempenho do professor estaria atrelado ao desempenho dos alunos, cujos referenciais, a exemplo do que ocorre com o uso do IDEB, recaem sobre indicadores de aferição de produto final. Além da óbvia conformação do projeto da escola e do currículo aos indicadores que, pela opção governamental, merecem ser avaliados, tal 
modelo de avaliação responsabiliza os profissionais envolvidos pelos resultados obtidos, punindo-os ou premiando-os pela via da remuneração.

Ainda que este capítulo tenha sido dedicado à análise das políticas de formação dos professores no contexto da emergência dos mecanismos de quasemercado educacional, não é possível desconsiderar as questões da carreira, posto que são parte de uma política mais ampla que evidenciam seu caráter e os objetivos governamentais para o setor.

Na seção seguinte retomaremos a análise dos documentos oficiais, buscando compreender como o quase-mercado dita a conduta das políticas de formação no Brasil nas últimas décadas.

\subsection{Diretrizes Curriculares Nacionais para a Formação de Professores da} Educação Básica

A Resolução CNE/CP n ${ }^{\circ}$ 1, de 18 de fevereiro de 2002 instituiu as Diretrizes Curriculares Nacionais para a Formação de Professores da Educação Básica, em nível superior, curso de licenciatura, de graduação plena.

De modo geral, a Resolução tratou dos princípios, fundamentos e procedimentos que deveriam ser observados na organização institucional e curricular dos estabelecimentos de ensino que viessem a ofertar tal formação.

Destaca-se nas Diretrizes a valorização das competências como concepção nuclear que deveria ser considerada na orientação dos cursos de formação. A esse respeito Maués (2004) destaca

A escolha da categoria competências como eixo nuclear das Diretrizes Curriculares para a formação dos professores da educação básica, em nível superior, traz essa marca (o utilitarismo, o 
pragmatismo, o condutivismo) que precisa ser considerada quando da definição da concepção de formação de professor que se vai adotar. Apesar de se saber que não há um vínculo determinístico entre educação e economia, não se pode ignorar, contudo, a relação existente e os desdobramentos que dela advém e que a pedagogia das competências pode contribuir grandemente para fortalecer essa relação, formando profissionais alinhados com as exigências do mercado. (p.15)

Parece emergir uma proposta de formação de caráter altamente utilitarista, cujo destaque e ênfase estariam na construção das competências essenciais ao exercício profissional.

O Parecer CNE/CP n 9 de 2001, donde se originaram as Diretrizes, trouxe a questão do "desenvolvimento das competências como princípio para a atividade profissional" (DIAS e LOPES, 2003, p. 1165). Tal desenvolvimento, portanto, visava "à aprendizagem de um conhecimento útil para o exercício da profissão" (DIAS e LOPES, 2003, p. 1165).

A aquisição de tais competências, conforme o Parecer, deveria ocorrer mediante uma ação teórico-prática, articulando a sistematização teórica com o fazer, e o fazer com a reflexão.

As competências tratam sempre de alguma forma de atuação, só existem "em situação" e, portanto, não podem ser aprendidas apenas no plano teórico nem no estritamente prático. A aprendizagem por competências permite a articulação entre teoria e prática e supera a tradicional dicotomia entre essas duas dimensões, definindo-se pela capacidade de mobilizar múltiplos recursos numa mesma situação, entre os quais os conhecimentos adquiridos na reflexão sobre as questões pedagógicas e aqueles construídos na vida profissional e pessoal, para responder às diferentes demandas das situações de trabalho. (BRASIL, 2002)

O Parecer definiu que a construção das competências resultava da construção dos conhecimentos e que era na aprendizagem dos conteúdos que se dava tal processo e conseqüente desenvolvimento. Assim era preciso que o currículo fosse 
dotado de conteúdos necessários ao desenvolvimento das competências exigidas para o exercício profissional.

Por fim, a avaliação foi contemplada pelas Diretrizes, sendo que esta deveria ter como referência as competências profissionais constituídas pelos professores em formação.

Importa destacar que ao eleger a categoria competência como eixo central da formação de professores para educação básica, as Diretrizes, ainda que não explicitamente, assumiram um modelo de formação operacional. Os saberes vinculados aos conhecimentos disciplinares ou aos sólidos fundamentos teóricos tiveram sua importância relativizada num contexto em que foram supervalorizados os saberes ligados aos procedimentos ou às formas de realizar tarefas, ainda que sustentados por saberes "mais acadêmicos".

A avaliação serviria, assim, para mensurar tais competências por meio de mecanismos e indicadores verificadores de desempenho gerados na aplicação dos saberes construídos. Assim, se as competências tinham uma lógica operacional, ou seja, conformar condutas para a execução das tarefas, sua avaliação deveria ocorrer tendo em vista o resultado final em termos de construção dessas condutas, que se manifestariam no desempenho docente, ou seja, o que o docente seria capaz de fazer ou realizar ao final do processo formativo.

O alinhamento dessa ótica ao ideário mercantil é evidente. Buscou-se impor um modelo de formação que, por um lado buscou responder às demandas do mercado, em termos de formação de profissionais flexíveis e adaptáveis, e, por outro lado, apoiou-se, enquanto processo, na "importação e utilização" de muitos mecanismos 
próprios desse mercado, como a valorização das competências, a avaliação de resultados e o racionalismo utilitarista.

Por fim, cabe destacar que as Diretrizes reafirmaram a necessidade de criação dos Institutos Superiores de Educação, num contexto de diversificação e diferenciação dos espaços de formação. Para Freitas (2003) a criação de novas instâncias de formação atendia aos objetivos de diversificação das instituições de Ensino Superior imposto pelos organismos internacionais de financiamento, visando reduzir os custos de formação (desenvolvida em universidades com investigação e pesquisa), dividir a oferta com as instituições privadas e tornar "mais ágil, prática e eficiente a formação dos quadros do magistério" (p. 1101)

Conforme já discutido anteriormente, a criação dos ISE representou uma alteração significativa nas políticas de formação de professores no Brasil, tanto no que se refere à diversificação das instituições, quanto no que tange aos cursos oferecidos. Os ISE, conforme já destacado no artigo 62 da LDB, manteriam:

I - cursos formadores de profissionais para a educação básica, inclusive o curso normal superior, destinado à formação de docentes para a educação infantil e para as primeiras séries do ensino fundamental;

II - programas de formação pedagógica para portadores de diplomas de educação superior que queiram se dedicar à educação básica; III - programas de educação continuada para os profissionais de educação dos diversos níveis. (BRASIL, 1996)

Em relação à formação de profissionais para atuação na Educação Infantil e séries iniciais do Ensino Fundamental, ficava clara a idéia de que isso se faria no curso Normal Superior e não mais na Pedagogia, o que poderia resultar na restrição da formação do pedagogo em cursos de bacharelado. Tal questão fez ressurgir o debate acerca da identidade e dos objetivos do curso de pedagogia. 
Previu-se, também a oferta de programas de formação pedagógica para portadores de diplomas de educação superior que, em conformidade com Parecer $\mathrm{CNE} / \mathrm{CP} \mathrm{n}^{\mathrm{o}}$ 04/97 deveriam ter carga horária de, pelo menos, 540 horas incluindo a parte teórica e prática, esta com duração mínima de 300 horas.

Ainda que os programas de formação pedagógica fossem destinados a suprir a falta de professores habilitados em determinadas disciplinas e localidades e tivessem caráter especial, promoveriam a formação de docentes cuja carga horária teórica seria de apenas 240 horas.

Todos esses elementos (diversificação dos espaços de formação, redução de custos de formação, ampliação da oferta privada, aligeiramento da formação) contribuíram para a consolidação de uma política de formação de professores comprometida com questões de cunho econômico.

Veremos a seguir como foi tratada a questão da formação de professores no Plano de Desenvolvimento da Educação - PDE.

\subsection{A formação dos Professores no Plano de Desenvolvimento da Educação}

O Plano de Desenvolvimento da Educação - PDE - tratou da formação dos professores na seção em que discutiu também o piso salarial nacional, buscando enfatizar a priorização de tais questões num contexto de valorização dos profissionais da educação.

No plano foram retomadas questões como o estabelecimento do piso salarial nacional e o comprometimento da União com a formação de professores para 
educação básica pública, por meio de dois programas integrados a Nova $\operatorname{Capes}^{27}$ : a Universidade Aberta do Brasil - UAB -, e o Programa Institucional de Bolsas de Iniciação à Docência - PIBID.

O programa Universidade Aberta do Brasil consiste na parceria entre entes federados e universidades públicas para oferta de cursos superiores e programas de formação continuada aos docentes - licenciaturas e especializações. Previu-se a instalação de pólos de apoio presencial, visto que os cursos seriam na modalidade semipresencial ou à distância. Segundo o documento de apresentação do PDE, “a UAB dialoga, assim, com objetivos do PNE” (BRASIL, 2007). Tais objetivos, segundo o documento eram:

\begin{abstract}
Ampliar, a partir da colaboração da União, dos estados e dos municípios, os programas de formação em serviço que assegurem a todos os professores a possibilidade de adquirir a qualificação mínima exigida pela LDB, observando as diretrizes e os parâmetros curriculares e Desenvolver programas de educação à distância que possam ser utilizados também em cursos semipresenciais modulares, de forma a tornar possível o cumprimento da meta anterior. (BRASIL, 2007)
\end{abstract}

Embora tenham sido contemplados de maneira articulada, UAB e Nova CAPES apresentavam distinções que merecem ser esclarecidas. O programa UAB previa, conforme já indicado, a oferta de formação inicial e continuada de professores para a educação básica, cuja metodologia utilizada seria a da educação à distância. Já a nova CAPES priorizou a oferta de formação inicial em cursos presenciais, deixando a educação à distância somente para a formação continuada.

\footnotetext{
${ }^{27}$ A Lei $\mathrm{n}^{\circ} 11502$ modificou as competências e a estrutura organizacional da fundação Coordenação de Aperfeiçoamento de Pessoal de Nível Superior - CAPES, passando a atribuir ao órgão a função de subsidiar o Ministério da Educação na formulação de políticas e no desenvolvimento de atividades de suporte à formação de profissionais de magistério para a educação básica e superior e para o desenvolvimento científico e tecnológico do País.
} 
Duas questões merecem destaque nessa análise. A primeira diz respeito ao papel das CAPES em relação aos processos de regulação da formação de professores da educação básica e a segunda está relacionada à questão da valorização da educação à distância como modalidade a ser utilizada, ainda que não exclusivamente, nos programas de formação docente.

Ficou determinado na Lei $\mathrm{n}^{0} 11.502 / 2007$ que a CAPES teria a finalidade de "induzir e fomentar, inclusive em regime de colaboração com os Estados, os Municípios e o Distrito Federal e exclusivamente mediante convênios com instituições de ensino superior públicas ou privadas, a formação inicial e continuada de profissionais de magistério, respeitada a liberdade acadêmica das instituições conveniadas". Instituiu-se, portanto, novas e diferentes competências para o órgão que historicamente esteve ligado aos processos de regulação dos programas de pósgraduação stricto sensu do Brasil.

As atividades da CAPES, conforme anunciado na página do órgão na Internet, encontram-se agrupadas em quatro linhas: avaliação da pós-graduação stricto sensu, acesso e divulgação da produção científica, investimentos na formação de recursos de alto nível no país e exterior, e promoção da cooperação científica internacional.

Todavia, merece destaque o rigor e a rigidez dos processos de regulação da pós-graduação "protagonizados" pela CAPES, cuja lógica assente na imposição de um modelo baseado na verificação de resultados de caráter altamente produtivista, suscita, nesse momento particular, questionamentos à respeito da transposição de tais valores à escola básica e à seus professores. 
O objetivo central de transferir para a CAPES a execução das políticas de formação, como anuncia o presidente desta Agência, é implantar um sistema de avaliação dos cursos existentes, nos moldes do que a instituição adota para a pós-graduação, transpondo, portanto, para os cursos de licenciaturas, os padrões de excelência da avaliação da pós-graduação. A transposição da lógica da pósgraduação às escolas de educação básica submetem a educação básica e seus profissionais à lógica produtivista que hoje caracteriza a pósgraduação em nosso país. Uma política com esta feição institui a competitividade entre as IES, mediante processos de creditação de instituições formadoras, e ainda a competitividade entre os professores da educação básica, pelos cursos de pós-graduação, que não estarão disponíveis a todos os professores, mas aos mais "qualificados" (FREITAS, 2007, 1218).

Entendemos que essa possível transposição da lógica e dos valores presentes nos processos de regulação da pós-graduação para a educação básica, pela via da formação de professores que atuam nesse nível, não é ocasional, tampouco desinteressada. Nos parece que tal movimento colabora para a consolidação de uma política educacional voltada para a produtividade e performatividade.

A segunda questão que nos propomos a analisar é a valorização da educação à distância nos programas de formação docente. Ainda que a nova CAPES tenha restringido o uso das metodologias de educação à distância aos programas de formação continuada, é inegável que essa modalidade foi institucionalizada na política pública de formação de professores.

Em relação ao PIBID cabe esclarecer que se tratava de um programa de bolsas de iniciação à docência, destinado a alunos de cursos de licenciatura de cursos presenciais que se dedicassem ao estágio nas escolas públicas e que se comprometessem com o exercício do magistério na rede pública, uma vez graduados. Foram eleitas áreas prioritárias, caracterizadas pela falta de professores com formação específica, a saber: física, química, biologia e matemática.

Percebe-se o compromisso da política educacional com programas de formação de caráter emergencial, voltados ao atendimento das metas de certificação de 
docentes. Por outro lado, consolida os propósitos de responsabilização dos docentes sobre sua formação, seja ela inicial ou continuada. 
CONSIDERAÇÕES FINAIS 
O presente trabalho apresentou uma investigação sobre a atual política educacional brasileira, tendo como foco as manifestações da concepção mercadológica de educação.

Nesse sentido, analisamos os principais documentos que consubstanciam, em termos normativos, a política educacional no que se refere, especificamente, à implantação de mecanismos de quase-mercado educacional.

Elegemos, para fins de cumprimento dos objetivos propostos, as categorias de análise (ou estudo) que, conforme nosso entendimento, poderiam revelar as concepções de educação de viés mercadológico, podendo assim dar-nos respostas específicas e mais precisas sobre a investigação.

A escolha das categorias - gestão, avaliação da educação básica e formação de professores - justifica-se pelo fato de que as políticas de quase-mercado educacional incidem fundamentalmente sobre essas áreas e acabam por revelar os grandes compromissos governamentais para com o setor da educação.

Importa recordar que o quase-mercado surgiu no contexto da "nova gestão pública" (década de 1980). A nova gestão pública combinava a introdução de métodos de gestão privada no setor público com a introdução de estruturas de incentivo na provisão de serviços públicos (ÁVILA de LIMA, 2007).

Parece-nos claro que a gestão educacional, a avaliação da educação básica e a formação de professores da forma como são tratadas nos documentos analisados têm servido para a concretização desse novo modelo de gestão pública de características gerenciais.

No que tange à gestão educacional, pudemos verificar, por meio da análise dos documentos, que a opção governamental pela introdução da gestão gerencial 
é justificada na assunção da ineficiência do modelo anterior, conseqüência da excessiva centralização e da burocratização. Tal questão guarda relação e extrema coerência com o pensamento reformista da época, que tinha na crise do Estado a razão para a promoção de alterações significativas nas funções e papéis estatais.

Transplanta-se, portanto, para a educação pública os mesmos referenciais de gestão adotados pelo Estado, cuja ênfase no mercado constitui a maior expressão.

O modelo de gestão gerencial favorecido na norma se vale de um importante mecanismo de suporte: a avaliação. A avaliação na gestão, mecanismo de regulação estatal, tem se mostrado capaz de provocar (ou incentivar) a mobilização social e a desresponsabilização estatal.

É interessante considerar que as sutilezas do quase-mercado - por não se concretizar como mercado clássico - manifestam-se nessa nova forma de gestão, que tem servido como instrumento de legitimação dos movimentos de contenção do Estado em favor de uma maior "participação" social, da socialização e do controle sobre os resultados alcançados (accountability), da descentralização, da desburocratização, da promoção da qualidade e da eficiência.

A concepção de avaliação presente nos documentos que tratam da educação básica revela o reconhecimento da avaliação como elemento de regulação do Estado. Nesse sentido, serve para o monitoramento e controle de resultados, na perspectiva da otimização da produção.

O que marca a convergência da concepção defendida com os valores do mercado (ou quase-mercado) é justamente a proposição do uso da avaliação. Propalada como instrumento de promoção de qualidade e igualdade, o emprego da 
avaliação (e mais precisamente de seus resultados), nessa concepção, tende a acarretar (o que já se evidencia na prática) a desigualdade e, principalmente, a sua naturalização. Tal tendência se manifesta, principalmente, em função do uso comparativo dos resultados que acabam por produzir a competição e, conseqüentemente, assumir a diferença como inerente ao processo.

É possível considerar, ainda, que o uso da avaliação, além da promoção da desigualdade, pode gerar um aumento de seletividade e exclusão no interior do sistema, fomentado pelo espírito competitivo de alcance de resultados que, muitas vezes, tem a recompensa financeira como importante indutor.

A avaliação torna-se, portanto, um elemento de relativização dos direitos sociais. Trata-se de um processo em que a educação é tratada como um bem privado, cuja "qualidade" pode ser medida e controlada e o controle é tido como um estímulo à busca dos níveis de qualidade impostos, ainda que nem todos possam ter acesso aos mesmos níveis de qualidade.

Quanto à formação de professores, os documentos analisados revelam uma concepção utilitarista e de cunho operacional, que contribui para a reafirmação e o espraiamento da cultura do desempenho.

É preciso considerar que as diretrizes gerais que norteiam as políticas de formação inicial e continuada de professores no Brasil objetivam a "diplomação" dos professores, de modo a promover a melhora dos indicadores nacionais. Dessa forma, revela-se a opção pela busca de índices e resultados, com conseqüências visíveis nos processos de formação.

Se por um lado os resultados quantitativos da política de formação de professores expressam a intenção do cumprimento de metas nacionais - quando se 
busca a diplomação dos professores -, por outro lado, a concepção de formação a ser desenvolvida também é orientada para a busca de resultados que deverão se materializar no exercício da docência.

A perspectiva produtivista que orienta as políticas de formação docente se amplia para além do contexto formativo, alcançando aspectos da carreira do professor e, a partir daí, passa a gerar novas demandas de formação.

O professor é formado para promover as aprendizagens necessárias ao alcance dos resultados previamente determinados. Tais resultados, por sua vez, tem servido como referência para medir a performance do professor com vistas à concessão de benefícios. Aliada a essa questão, a supervalorização do titulo (diploma) e a busca por uma formação que possa proporcionar um maior retorno em termos de resultados, acabam por gerar uma maior procura a cursos cuja qualidade nem sempre é defensável. O aligeiramento, a superficialidade e o caráter essencialmente operativo são alguns atributos comumente relacionados aos cursos de formação de professores atualmente ofertados, muitos deles à distância.

Evidencia-se, portanto, a coerência da política de formação de professores com o espírito mercantil que se expandiu no contexto de redefinição do Estado.

Em linhas gerais, pode-se considerar que os mecanismos de quasemercado educacional estão presentes nos documentos que tratam da política educacional brasileira e se revelam pelas formas e usos da gestão educacional, da avaliação e da formação de professores.

Entretanto, parece haver um movimento rumo a uma nova fase que, segundo Arelaro (2007) seria a "fase da privatização sumária, em nome da eficiência, 
com redução significativa dos investimentos nas políticas sociais" (p.913). Tal tese merece ser considerada, posto que, embora a educação básica seja considerada uma atividade exclusiva do Estado, a prestação de tal serviço pode se dar pela via do subsidio. Já é fato nas escolas públicas brasileiras a "privatização" dos currículos compra de materiais didáticos -, a "privatização" da gestão - contratação de assessorias externas - e a "privatização" da oferta de alguns serviços - informática educacional, por exemplo. A já tênue divisa entre mercado e Estado (no contexto do quase-mercado educacional) tende, nessa perspectiva, a desaparecer.

Cabe, por fim, relembrar que nessa imbricada relação o setor públiconão-estatal tem se apresentado como uma opção governamental de transferência de responsabilidades.

Não podemos, ao menos por hora, afirmar que a nova fase vai se instalar em definitivo, contudo, é possível prever drásticas conseqüências para a educação pública. 


\section{REFERÊNCIAS}

ABRUCIO, Fernando Luiz. O impacto do modelo gerencial na Administração pública: um breve estudo sobre a experiência internacional. Brasília: ENAP, 1997 (Cadernos ENAP, $\left.n^{\circ} 10\right)$

AFONSO, A. J. Políticas educativas e avaliação educacional - para uma análise sociológica da Reforma Educativa em Portugal (1985-1995). Braga: Universidade do Minho - Instituto de Educação e Psicologia - Centro de estudos em Educação e Psicologia, 1998.

. Estado, mercado, comunidade e avaliação: esboço para uma rearticulação crítica. Educação \& Sociedade, Campinas, CEDES: 1999.

. Estado, globalização e políticas educacionais: elementos para uma agenda de investigação. Revista Brasileira de Educação, 2003.

. Escola pública, Gerencialismo e Accountability. Jornal Página da Educação, ano 12, no 126, p. 21, Agosto/Setembro 2003.

. Os exames não promoverão nunca a melhoria da qualidade da educação escolar. Revista A página da educação. N. ${ }^{\circ}$ 158, Ano 15, Julho 2006. Disponível em http://www.apagina.pt/?aba=7\&cat $=158 \&$ doc $=11684 \& \mathrm{mid}=2$. Acessado em 24/11/2009.

ALVES, Maria Teresa Gonzaga. Conteúdos ideológicos da nova direita no município de São Paulo: análise de surveys. Opin. Publica [online]. 2000, vol.6, n.2.

ANDERSON, P. Balanço do neoliberalismo. In: SADER, E e GENTILI, P (orgs). Rio de Janeiro: Paz e Terra, 1995

ARELARO, Lisete R. G., Formulação e implementação das políticas públicas em educação e as parcerias público-privadas: impasse democrático ou mistificação política? Educação e Sociedade. Campinas, 2007

ÁVILA DE LIMA, J. Redes na Educação: questões políticas e conceptuais. Revista. Portuguesa de Educação. 2007 
AZEVEDO, J. M. L. A educação como política pública. Campinas SP. Autores Associados, 1997. . Implicações da nova lógica de ação do Estado para a educação municipal. Educação e Sociedade. 2002 . O projeto político-pedagógico no contexto da gestão escolar. Jornal do Professor. 2005. Disponível em http://escoladegestores.mec.gov.br/site/5sala_planejamento_praticas_gestao_escolar/pdf/u1_saibamais1.pdf. Acessado em $13 / 03 / 2009$

BANCO MUNDIAL. Prioridades y estrategias para la educación. Washington, D.C.: Banco Mundial, 1996.

BARDIN, L. Análise de conteúdo. Lisboa: Edições 70, 1997.

BARROSO, João. (org). O Estado, a educação e a regulação das políticas públicas.Educação \& Sociedade, Campinas, v. 26, n॰92, out.2005

BIANCHETTI, R.G., Modelo neoliberal e politicas educacionais. São Paulo: Cortez, 2005

BRASIL. Constituição Federal de 1988. Disponível em http://www.senado.gov.br/bdtextual/const88/const88.htm. Acessado em 25/05/2009. Plano Diretor da Reforma do Aparelho do Estado. Disponível em https://www.planalto.gov.br/publi_04/COLECAO/PLANDI.HTM. Acessado em 02/02/2004.

.Ministério da Educação. Instituto Nacional de Estudos e Pesquisas. Enem: seu futuro passa por aqui. Brasília: Inep, 1999b.

.Ministério da Educação Lei de Diretrizes e Bases da Educação Nacional. Lei $n^{\circ}$ 9394, 20 de dezembro de 1996 .Ministério da Educação. Conselho Nacional de Educação. PARECER CNE/CP 009/2001. D. O. U. de 18/1/2002 .Ministério da Educação. Instituto Nacional de Estudos e Pesquisas Educacionais. Exame Nacional do Ensino Médio. Documento Básico. 1999a 
.Ministério da Educação. Instituto Nacional de Estudos e Pesquisas. Portaria $n^{o}$ 109, de 27 de maio de 2009. 2009a.

.Ministério da Educação. Instituto Nacional de Estudos e Pesquisas. Nota Técnica. Notas Médias do Enem 2008 por Município e por Escola dos Alunos Concluintes do Ensino Médio em 2008. 2009b.

.Ministério da Educação. Plano de Desenvolvimento da Educação: razões, princípios e programas. Brasília: MEC, 2007.

.Ministério da Educação. Plano Nacional de Educação. Brasília: MEC, 2001

.Ministério da Educação. Portaria $N^{o}$ 931, DE 21 DE MARÇO DE 2005.

DOU n ${ }^{\circ} 55.22 / 03 / 2005$.

BRESSER PEREIRA, L.C. e Spink, P. (orgs) Reforma do Estado e Administração Pública Gerencial. Editora Fundação Getúlio Vargas. Rio de Janeiro: 1998

BRESSER PEREIRA, L C. Desenvolvimento e crise no Brasil; história, economia e política de Getúlio Vargas a Lula. São Paulo, 2003. . Da administração pública burocrática à gerencial. In BRESSER PEREIRA, L. C. e Spink, P. (Orgs.), Reforma do Estado e Administração Pública Gerencial, Rio de Janeiro: Editora FGV, 1999

BRZEZINSKI, I. A formação e a carreira de profissionais da educação na LDB 9.394/96: possibilidades e perplexidades. In: BRZEZINSKI, I. (Org.). LDB Interpretada: diversos olhares se entrecruzam. São Paulo, SP: Editora Cortez. p. 147167

BUENO, M. S. S. (Org.) ; M.L.ZIBAS, D. (Org.) ; AGUIAR, M. A. (Org.) . O ensino médio e a reforma da educação básica. Brasília D.F.: Plano, 2002 BUENO, M. S. S. . Descentralização e municipalização em São Paulo: conceitos e preconceitos. In: Bueno, Maria Sylvia Simões.; Martins, Angela Maria; Oliveira, Cleiton. (Org.). Descentralização do Estado e Municipalização do Ensino: problemas e perspectivas. Belo Horizonte: DP\&A, 2004.

CAMARGO, E.A.S.P. et al. Educação: de direito de cidadania a mercadoria. Educação \& Sociedade, 2003 
CAMARGO, R. B. de; PINTO, J. M. R. e GUIMARAES, J. L. Sobre o financiamento no Plano de Desenvolvimento da Educação. Cadernos de Pesquisa. 2008.

CASASSUS, J. Uma nota crítica sobre a avaliação estandardizada. A perda de qualidade e a segmentação social. Sísifo. Revista de Ciências da Educação: 2009.

CHAUÍ, Marilena. (1999). A universidade operacional. Folha de S. Paulo, São Paulo, Domingo, 09 de maio de 1999. Mais! 5-3 Brasil 500 D.C. Disponível em http://www1.folha.uol.com.br/fol/brasil500/dc_1_3.htm. Acessado em 13/01/2009. CHUBB, J e MOE, T. Politics, markets and America' Schools. Washington: Brookings, 1990

COUTINHO, K.D. Educação como mercadoria: o público e o privado no caso dos shopping centers. Educação \& Sociedade, 2003.

DALE, R. A promoção do mercado educacional e a polarização da educação. Revista Educação, Sociedade \& Culturas, $\mathrm{n}^{\circ}$ 2, Porto: Edições Afrontamento,1994

DAVIES, N. O governo Lula e a educação: a deserção do Estado continua?. Educação. \& Sociedade, Campinas: 2004

DI PIERRO, M.C. e GRACIANO, M. A educação de jovens e adultos no Brasil. Informe apresentado à Oficina Regional da UNESCO para América Latina y Caribe. Disponível em http://www.acaoeducativa.com.br/downloads/relorealc.pdf. Acessado em $15 / 06 / 2009$

DIAS, R. E.; LOPES, A. C. Competências na formação de professores no Brasil: o que (não) há de novo. In: Educação \& sociedade. Campinas. vol. 24, nº 85, p. 1155-1177, 2003.

DOURADO, L. F. Reforma do Estado e as políticas para a educação superior no Brasil nos anos 90. Educaçăo \& Sociedade. Campinas, 2002 - A reforma do Estado e as politicas de formação de professores nos anos 1990. In: DOURADO, L.F.; PARO, V.H. Políticas públicas \& educação básica. São Paulo: Xamã, 2001. 
DOURADO, L.F.; BUENO, M.S.S. O público e o privado em educação. In:

WITTMANN, L.C.; GRACINDO, R.V. (Coords.). O estado da arte em política e gestão da educação no Brasil: 1991 a 1997. Brasília, n.6, 1999.

FELIX, M. F. C. Administração escolar: Um problema educativo ou empresarial. São Paulo: Cortez, 1989.

FERNANDES, R. Índice de Desenvolvimento da Educação Básica (Ideb). Disponível em http://www.publicacoes.inep.gov.br/arquivos/\%7B9C976990-7D8D-4610-AA7CFF0B82DBAE97\%7D_Texto_para_discuss\%C3\%A3o26.pdf. Acessado em $10 / 01 / 2010$.

FIORI, J.L. O Brasil na mudança mundial: espaços em disputa. In: Brasil em Desenvolvimento: Ciclos de Seminários IE-UFRJ/CEPAL. Rio de Janeiro, 2003. FLEURY, Sonia. Fundamentos de la Reforma del Estado. In: Anais do ENANPAD, 2001.

FRANCO, M. L. P. B. Análise de conteúdo. Brasília: Líber Livro, 2008

FREITAS, H. C. L. de. A (nova) política de formação de professores: a prioridade postergada. Educação e Sociedade. Campinas. CEDES: 2007.

Certificação docente e formação do educador: regulação e desprofissionalização. Educação e Sociedade. Campinas. CEDES: 2003. de. Formação de professores no Brasil: 10 anos de embate entre projetos de formação. Educação e Sociedade. Campinas. CEDES: 2002.

GATTI, B. A. Formação de professores e carreira: problemas e movimentos de renovação. Campinas, SP: Autores Associados, 2000.

GENTILI, P.; SILVA, T.T. Neoliberalismo, qualidade total e educação: visões críticas. 2. ed. Petrópolis: Vozes, 1995.

GIDDENS, A. A terceira via: reflexões sobre o impasse político atual e o futuro da social-democracia. 5. ed. Rio de Janeiro: Record, 2005

GODOY, A.S. Pesquisa Qualitativa: tipos fundamentais. In REA- Revista de Administração de Empresas, v.35 n. ${ }^{\text {o } 3,1995 .}$ 
KRAWCZYK, N., CAMPOS, M. e HADDAD, S. orgs. O Cenário Educacional LatinoAmericano no Limiar do Século XXI, São Paulo: Autores Associados, 2001.

KUENZER, A. Z. As políticas de formação: a constituição da identidade do professor sobrante. Educação e Sociedade. 1999

LE GRAND, J. (1996). Los cuasi mercados y la política social. In: PLANAS, Esteve Oroval. (org.). (1996). Economía de la educacíon. Barcelona: Ariel.

LESSARD, C. Regulação múltipla e autonomia profissional dos professores: comparação entre o Quebec e o Canadá. Educação em Revista, Universidade Federal de Minas Gerais. Faculdade de Educação. Belo Horizonte: FaE/UFMG, n॰ 44, dez.2006. LEVACIC, R (1995) Local Management of Schools: Analysis and Practice, Milton Keynes, Open University Press

LIMA, L. C. A Escola como Organização e a Participação na Organização Escolar. Braga/Pt: Universidade do Minho, 1992.

LIMA, M.C. Desenvolvimento e globalização na periferia: o elo perdido.Perspectivas, São Paulo, 2007.

LOPES, A.C.; DIAS, R. E. Competências na formação de professores no Brasil: o que (não) há de novo. Educação \& Sociedade, 2003

LUMERTZ, J.S. A parceria público-privada na educação: implicações para a gestão da escola. Dissertação de Mestrado. Universidade Federal do Rio Grande do Sul: 2008. MACHADO, L. M. . Administração de escolas de educação infantil: entre os pés e as asas. Educação em Foco, Juiz de Fora, v. 9, n. 1 e 2, p. 85-102, 2005.

MAGNANI, L.R. Ensino, pesquisa, extensão e a nova tipologia no ensino superior brasileiro. [on line]. Disponível em http://www.uerj.br/ anped11/25/trab 13.rtf. Acessado em 26/08/2006 MARTINS, A. A descentralização como eixo das reformas do ensino: uma discussão da literatura. Educação e Sociedade, Campinas, CEDES: 2001.

MARTINS, H. F. Administração para o Desenvolvimento; a relevância em busca da disciplina. Governança e Desenvolvimento, ano 1, n. 1, abril 2004 
MATTOS, P.T.L. Regulação Econômica e Democracia: o Debate Europeu, São Paulo: Singular, 2006.

MAUÉS, O. As politicas de formação e a pedagogia das competências. In: REUNIÃO DA $A N P E D, 27,2004$, Caxambu. Sociedade democrática e educação: qual universidade? Caxambu, MG: ANPED, 2004. 1 CD-ROM.

MINTO, L. W. . Plano de Desenvolvimento da Educação (PDE): centralidade do ensino à distância e esvaziamento do conteúdo nas políticas educacionais recentes. 2009.

OLIVEIRA, C. de. Gestão da educação: União, Estado/DF, município e escola. In: Política e Gestão da educação: dois olhares. Rio de Janeiro: DP\&A, 2002.

OLIVEIRA, D A ; SILVA, M. J. A. . Regulação: A Avaliação de Sistemas de Ensino no Contexto da Regulação das Políticas Públicas. In: XXIII Simpósio Brasileiro de Política e Administração da Educação, V Congresso Luso-Brasileiro de Política e Administração da Educação, I Colóquio Ibero-Americano de Política e Administração da Educação, 2007, Porto Alegre. Por uma Escola de Qualidade para Todos, 2007. OLIVEIRA, D A. A gestão democrática da educação no contexto da reforma do estado. IN: FERREIRA, N S C (Org.) Gestão da educação: impasses, perspectivas e compromissos. São Paulo: Cortez, 2006.

OLIVEIRA, S B. Ação Social e Terceiro Setor no Brasil. Pontifícia Universidade Católica de São Paulo, 2005. 151f. Dissertação (Mestrado) em Economia Política. Disponível em http://www.fonte.org.br/documentos/mestrado_sidney.pdf. Acessado em $18 / 06 / 2009$

PARO, V. H. Administração escolar: introdução crítica. 2. ed. São Paulo: Cortez: Autores Associados, 1987. . Participação popular na gestão da escola pública. Tese de Livre Docência, Faculdade de Educação da USP, 1991. PERONI, Vera ; ADRIÃO, T. . Reforma da ação estatal e as estratégias para a configuração do público não-estatal na educação básica brasileira. In: $27^{\mathrm{a}}$ Reunião Anual da Anped, 2004, Caxambu. Anais da 27 Reunião Anual da Anped, 2004. p. 1-16. 
PINTO, J. M. R. Financiamento da educação no Brasil: um balanço do governo FHC. (1995-2002). Educação e Sociedade, Campinas, 2002

.O financiamento do PDE. Seminário itinerante .O Plano de

Desenvolvimento da Educação (PDE) em debate nas universidades públicas paulistas.

Disponível em http://cecemca.rc.unesp.br/cecemca/seminario_pde. Acessado em $14 / 12 / 2009$

PORTELLA FILHO., P. O ajustamento na América Latina: crítica ao modelo de Washington. Lua Nova, 1994.

POWER, S. e WHITTY, G. Mercados educacionais e a comunidade. Educação e Sociedade.Campinas, CEDES: 2003

ROSSI, V. L. S. Desafio à escola pública: tomar em suas mãos seu próprio destino. Cadernos Cedes. Campinas: 2001.

RUSSO, M. H. Escola e paradigmas de Gestão. ECCOS - Revista Científica. Centro Universitário Nove de Julho, v. 6, n. 1, p. 25-42, jun. 2004. . Teoria e prática na administração escolar: divergências e convergências . São Paulo: FEUSP, 1995. Tese de Doutorado SÁ, V. O discurso da Qualidade no contexto da recomposição das desigualdades em educação. Revista Brasileira de Estudos Pedagógicos, vol. 89, nº 223, pp. 425-444, 2008 .

SANTOMÉ, J. T. A construção da escola pública como instituição democrática: poder e participação da comunidade. Currículo sem Fronteiras. 2001. Disponível em http://www.curriculosemfronteiras.org. Acessado em 20/01/2008.

SANTOS, B.S. Os processos de globalização. Disponível em http://www.eurozine.com/articles/2002-08-22-santos-pt.html. Acessado em 23/03/2008. SANTOS, L. L. C. Formação de professores na cultura do desempenho. Educação \& Sociedade, Campinas: 2004

SÃO PAULO. ESTADO. Lei Complementar $N^{o}$ 1078, de 17 de dezembro de 2008. D.O.E. de 18/12/2008

SAVIANI. PDE só acontece com colaboração de gestores. Revista Nova Escola. 2009 
SGUISSARDI, V. Rumo à Universidade Competitiva: Na Modernização conservadora a universidade perde sua face, sua alma e sua identidade históricas. Perspectiva (Erexim), Florianópolis, v. 20, n. 2, p. 239-268, 2002. . Universidade pública estatal: entre o público e o privado/mercantil.

Educação e Sociedade, Campinas: CEDES, 2005.

SILVA JÚNIOR, C. A. O espaço da administração no tempo da gestão. In:

MACHADO, L. M.; FERREIRA, N. S. C. (Org.). Política e gestão da educação: dois olhares. Rio de Janeiro: DP\&A, 2002.

SILVA JUNIOR, J R. Reformas do Estado e da educação e as políticas públicas para a formação de professores a distância: implicações políticas e teóricas. Rev. Bras. Educ. [online]. 2003, n.24

SILVA, I G . A reforma do Estado Brasileiro nos anos 90: processos e contradições. Lutas Sociais (PUCSP), São Paulo, v. 7, p. 81-94, 2001.

SILVA, M.A. Intervenção e consentimento: a política educacional do Banco Mundial. São Paulo: FAPESP e Autores Associados, 2002.

SOUSA, S M Z L. A avaliação na organização do ensino em ciclos. Revista de Educação (Lisboa), São Paulo, n. 13, p. 30-36, 2001.

Possíveis impactos das políticas de avaliação no currículo escolar.

Cadernos de Pesquisa, 2003.

SOUSA, S. M. Z. L. e OLIVEIRA, R. P. Políticas de Avaliação da Educação e quase mercado no Brasil. Educação \& Sociedade, Campinas: 2003.

SOUSA, S.M. Z.L e LOPES V.V. Avaliação nas políticas educacionais atuais reitera desigualdades. Revista Adusp. № 46. Janeiro 2010. Disponível em http://www.adusp.org.br/revista/46/rev46.pdf. Acessado em 25/01/2010.

SOUZA, S. C. ; BUENO, M. S. S. . A mercantilização do ensino fundamental: experiências do quase-mercado educacional.. Revista Iberoamericana de Educación (Online), v. 2, p. 1-15, 2007. 
VASCONCELOS, A C C A. Reforço escolar e recuperação em uma rede municipal de ensino: o percurso entre o dito e o feito. 2009. 153f. Dissertação (Mestrado) Faculdade de Filosofia e Ciências, Universidade Estadual Paulista, Marília, 2009. VOIGT, L. Elementos introdutórios sobre terceiro setor no Brasil. Disponível em http://www.arf.org.br/arquivos/leo.doc. Acessado em 20/06/2009 VEIGA, I. P. A. (Org.). Caminhos da Profissionalização do Magistério. Campinas, SP: Editora Papirus, 1998 (Coleção Magistério: Formação e Trabalho Pedagógico). WHITTY, G.; POWER, S. A escola, o Estado e o mercado: a investigação do campo actualizada. Currículo Sem Fronteiras, Lisboa, v. 2, n. 1, p. 15-40, 2002. Disponível em: HTTP://www.curriculosemfronteiras.org. Acessado em 02/02/2008 